Gardner-Webb University

Digital Commons @ Gardner-Webb University

2019

Perceptions of the Impact of Quality Professional Development on the Sustainability of a One-to-One Computing Initiative at the High School Level

Kerry Morrison

Follow this and additional works at: https://digitalcommons.gardner-webb.edu/education_etd

Part of the Educational Assessment, Evaluation, and Research Commons, and the Teacher Education and Professional Development Commons 


\title{
PERCEPTIONS OF THE IMPACT OF QUALITY PROFESSIONAL DEVELOPMENT ON THE SUSTAINABILITY OF A ONE-TO-ONE COMPUTING INITIATIVE AT THE HIGH SCHOOL LEVEL
}

\author{
By \\ Kerry Morrison
}

\begin{abstract}
A Dissertation Submitted to the Gardner-Webb University School of Education in Partial Fulfillment of the Requirements for the Degree of Doctor of Education
\end{abstract}

Gardner-Webb University 2019 


\section{Approval Page}

This dissertation was submitted by Kerry Morrison under the direction of the persons listed below. It was submitted to the Gardner-Webb University School of Education and approved in partial fulfillment of the requirements for the degree of Doctor of Education at Gardner-Webb University.

Bruce Boyles, Ed.D.

Date

Committee Chair

Stephen Laws, Ed.D.

Date

Committee Member

Kimberli Stoffel, Ph.D.

Date

Committee Member

Prince Bull, Ph.D.

Date

Dean of the School of Education 


\section{Acknowledgements}

"But as for you, be strong and do not give up, for your work will be rewarded."

\section{Chronicles 15:7}

I want to thank my family for the support they gave me during the time when I was completing my dissertation. It ensured that I continued no matter how I felt. How can I tell my children to never give up if I buckled during the process? My children are not only my heart; they are also my reason for living.

My children, I love you so much, and it is for you that I completed my dissertation. It is with pride that I will always tell you that no matter what is going on in your life, always finish what you have started. I love you my babies!

Acknowledgement must also be made to Dr. Bruce Boyles for his constant support throughout this process. No matter how many questions I had, he tried his best to provide me with an answer. Thanks to all the members on my committee for your help. I must also say thank you to Dr. Bull for his feedback. It is and was greatly appreciated!

This has been a journey that will always be near and dear to my heart. This is it! I am blessed! I am happy! I will never forget this juncture of my life for so many reasons! Glory to God! 


\begin{abstract}
PERCEPTIONS OF THE IMPACT OF QUALITY OF PROFESSIONAL DEVELOPMENT ON THE SUSTAINABILITY OF A ONE-TO-ONE COMPUTING INITIATIVE AT THE HIGH SCHOOL LEVEL. Morrison, Kerry, 2019: Dissertation, Gardner-Webb University. It has been said that education is the key to success, and today's youth are tomorrow's human resources. This is the $21^{\text {st }}$ century; and students, who will be the human resources of tomorrow, are being prepared for jobs that may not even exist today. Legislators, policy makers, and researchers have encouraged methods to ensure teachers deliver high quality instruction, including requiring that teachers complete specific training, possess a minimum level of content knowledge, and use curriculum materials and professional development resources available from schools and districts (Hill, Blazar, \& Lynch, 2015). As a result, teachers need to be exposing students to lessons that are technologically enhanced as they prepare students for the future. This study is a qualitative analysis of a survey and interviews that seek to examine the impact of quality professional development and teacher exposure to technology on the sustainability of one-to-one computing initiatives. This study is supported by the following theories: the Technological Pedagogical Content Knowledge (TPACK) framework and Bandura's (1977) self-efficacy theory. This study discussed the impact of the TPACK framework and Bandura's self-efficacy theory on the sustainability of a one-to one computing initiative. The key findings in this study were that content-driven professional development, clear expectations for technology use in classrooms, and the availability of school-based instructional coaches can impact the sustainability of a one-to-one
\end{abstract}


computing initiative. As is defined by Bandura's self-efficacy theory, teachers are more likely to implement technology in the classroom that can sustain a one-to-one computing initiative if they are confident in their ability to use technology. This study also discussed recommendations for practice that school districts can use as they sustain a one-to-one computing initiative.

Keywords: professional development, one-to-one computing initiative, sustainability, impact initiative, traditional high schools, nontraditional high schools, TPACK, self-efficacy, 


\section{Table of Contents}

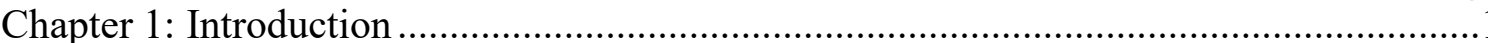

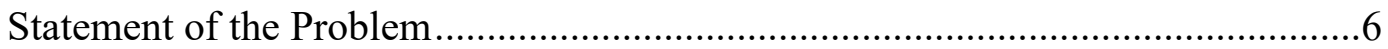

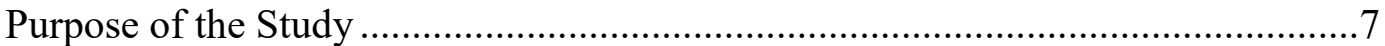

The Research Problem .......................................................................................

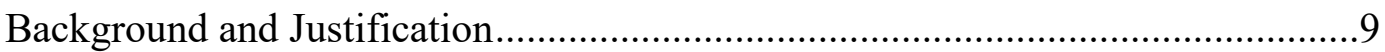

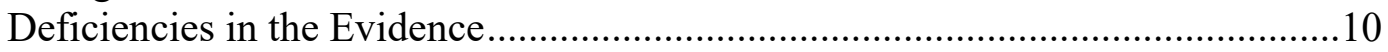

Research Questions .........................................................................................

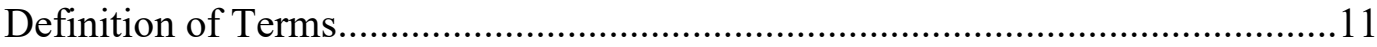

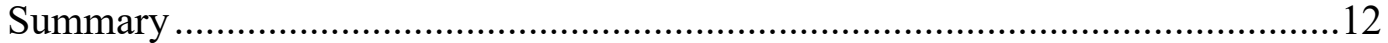

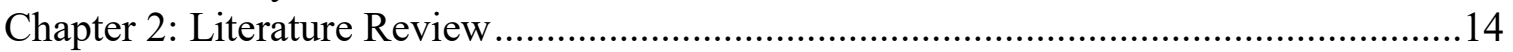

Impact of TPACK Professional Development on Teacher Self-Efficacy

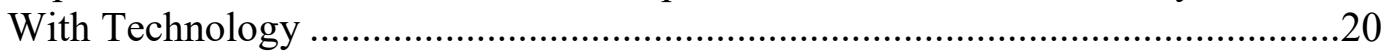

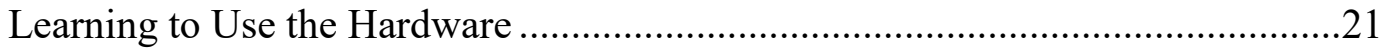

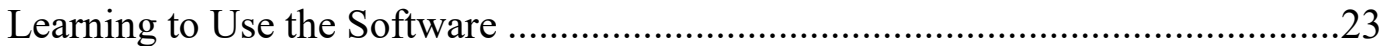

Time Spent on Professional Development for One-to-one Computing

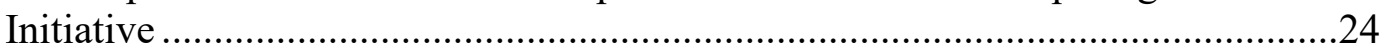

Time Allotted for Teacher Access to Computing Devices ....................................22

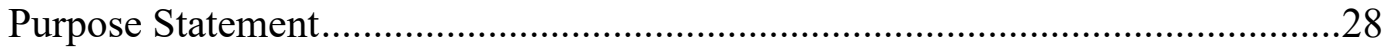

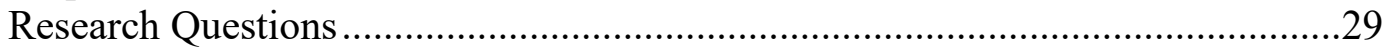

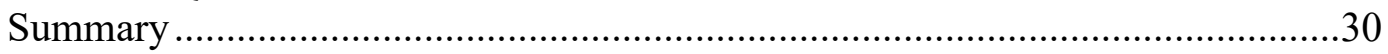

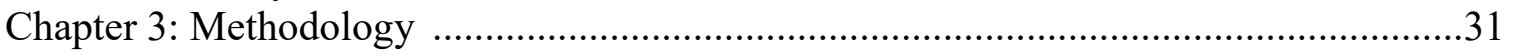

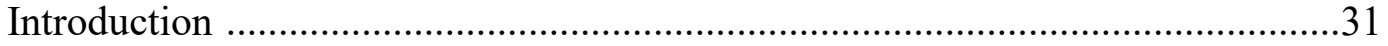

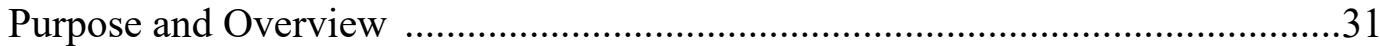

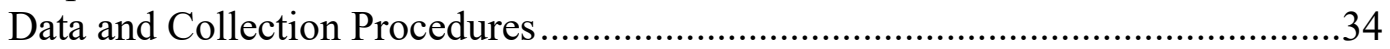

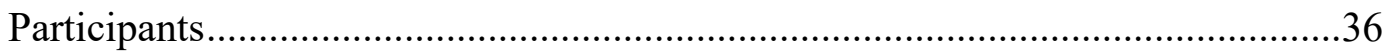

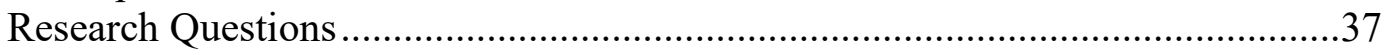

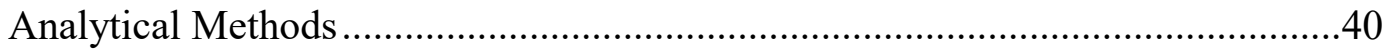

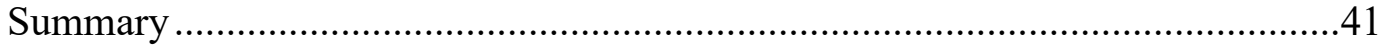

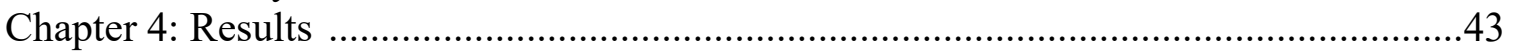

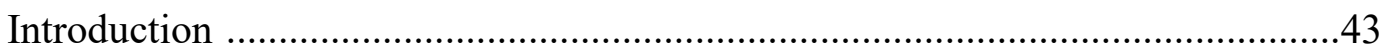

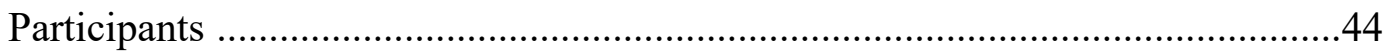

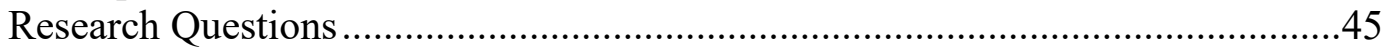

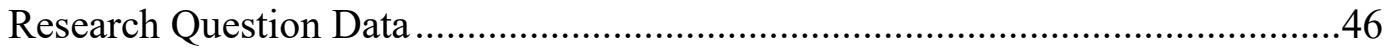

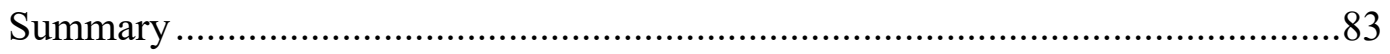

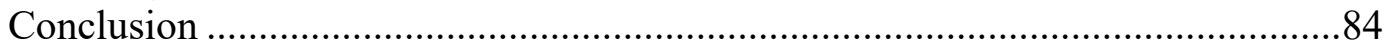

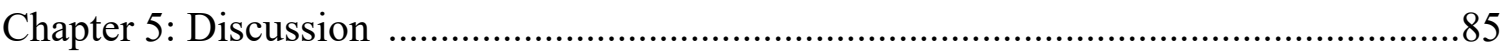

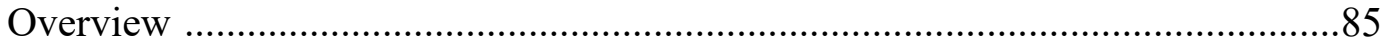

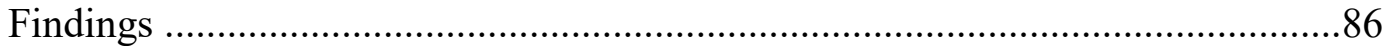

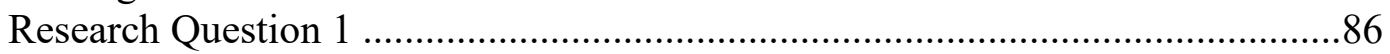

Content Specific Professional Development .....................................................8

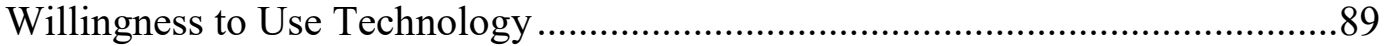

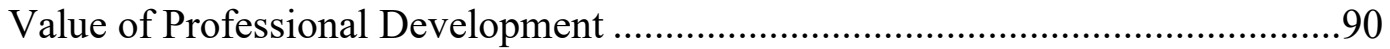

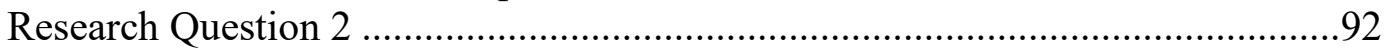




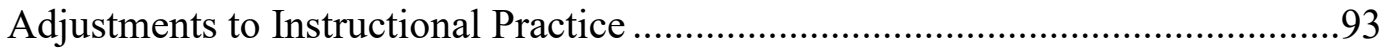

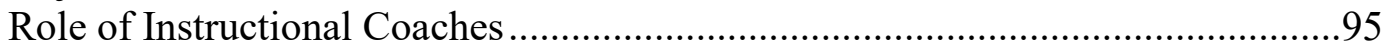

Teacher Expectation Contracts ........................................................................

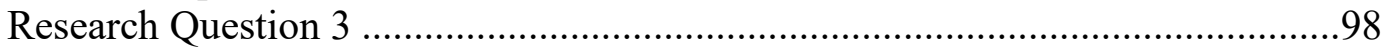

Recommendations for Sustaining a One-to-One Computing Initiative................100

Recommendations for Future Research ..........................................................101

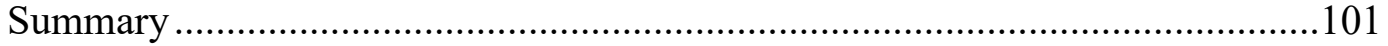

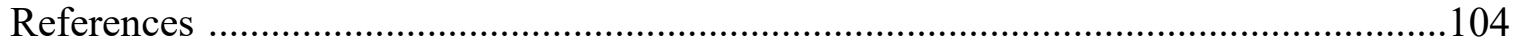

Appendices

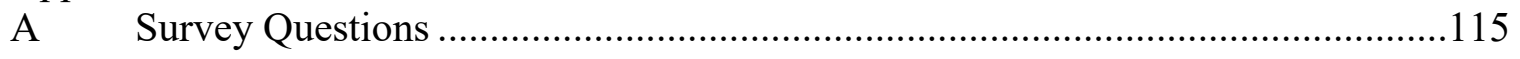

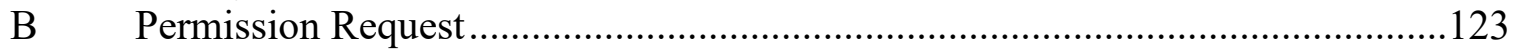

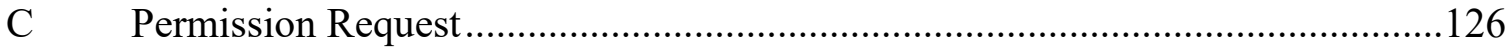

D Survey Participation Informed Consent Form ..................................................128

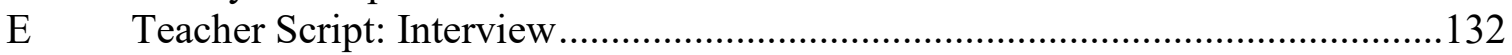

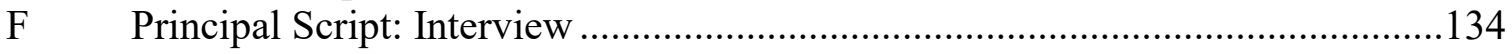

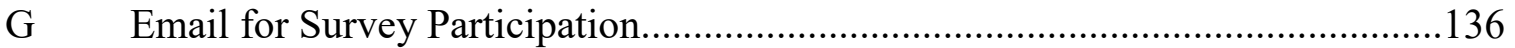

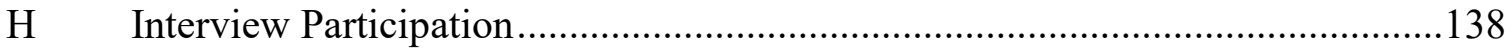

Tables

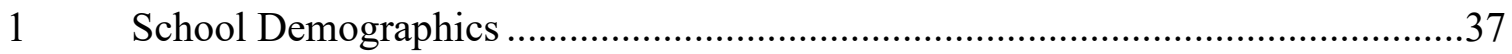

2 Survey Questions and Interview Questions for Research Question 1 ...................46

3 Survey Questions and Interview Questions for Research Question 2 ...................61

4 Survey Questions and Interview Questions for Research Question 3 ...................79

Figures

1 Technological Pedagogical Content Knowledge ................................................16

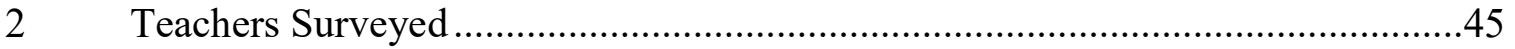

3 Teaching Experiences of the Teachers at Schools A, B, and C .............................47

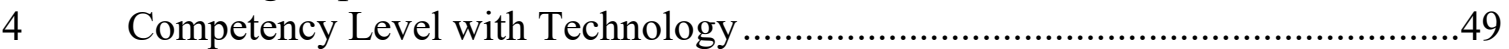

5 Learning Activity that was Designed to Challenge Students to Think

in a Critical Manner ..............................................................................................53

6 Technology Used to Create a Web Page or Content Management Platform Where Students Can Access Learning Materials and Submit Assignments...........55

$7 \quad$ Frequency with which Students Collaborated on Assignments.............................57

8 Frequency that Students were asked to Post Assignments or to Communicate

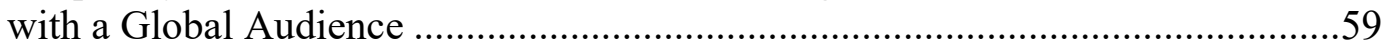

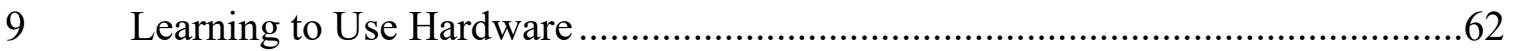

10 Learning to Use Software and Application Programs ..........................................63

11 Learning to Use Content Management and Instructional Delivery Platforms.......63

12 Learning to Implement the Technology within Instruction ...................................64

13 Frequency of Technology Use Before and After One-to-One Implementation

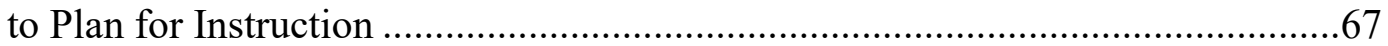

14 How Often Technology was used to Deliver Instruction........................................69

15 How Often was Technology used to Assess Student Learning ..............................71

16 Participant Use of Digital Resources to Supplement Existing Textbook and/or Curriculum ...........................................................................................73

17 Participants Use Technology to Create and/or Download Presentations that Students can Access Outside of the Classroom 
18 Participant Use of Technology to Differentiate or Personalize Instruction ...........77

19 Students Use Technology to Complete Classroom Learning Assignments...........78

20 Length of Time Teachers had Access to Their Computing Device Prior to Students. .80

21 Length of Time Teachers had Professional Development in Preparation for One-to-One Computing Initiative 


\section{Chapter 1: Introduction}

“Today's students, known as digital natives, net-generation, the Google generation or the millennial are radically different from those of the past. Born into an era of instant connectivity and networking, they explore the world in an entirely new way" (Sutherland, 2016, p. 1). Students today interact differently, and they want instant feedback for they are a "generation of students that grew up with technologies. The internet, cell phones, and Facebook, allows them to connect with the world instantly" (Sutherland, 2016, p. 1). While learners in the past "valued face-to-face meetings, today's students prefer to connect via email and text messages” (Sutherland, 2016, p. 1). Technology has allowed us to "get the same information and value from a digital meeting, that the previous generation got from an office meeting" (Sutherland, 2016, p. $1)$.

It has been said that education is the key to success, and today's youth are tomorrow's human resources. This is the $21^{\text {st }}$ century; and students, who will be the human resource of tomorrow, are being prepared for jobs that may not exist today. Legislators, policy makers, and researchers have encouraged methods to ensure that teachers deliver high-quality instruction. This includes requiring teachers to complete specific training, possess a minimum level of content knowledge, and use curriculum materials and professional development resources available from schools and districts (Hill et al., 2015). As a result, teachers need to be exposing students to lessons that are technologically enhanced as they prepare students for the future. There are a number of ways to do this, which include the use of computers and other technology resources in the classroom. It was once considered too expensive for public high schools to have computing devices assigned to each student who attends the school (Ferguson, 2012); 
however, the availability of lower cost computer technology has made it possible for schools to consider investing in computing devices and to dispense the technology into students' hands daily (U.S. Department of Education [USDOE], 2013a).

No Child Left Behind Act of 2001 (2002) stressed the importance of technology in the classroom. Goals listed in the legislation included "the improvement of student achievement through the use of technology in elementary and secondary schools" (No Child Left Behind Act, 2002, p. 1) and to "integrate technology resources and systems with teacher training and curriculum development, in an effort to establish research-based instructional methods that can be widely implemented as best practices" (No Child Left Behind Act, 2002, p. 2). The Elementary Secondary Education Act "provides incentives for states to adopt academic standards that prepare students to succeed in college and the workplace" (USDOE, 2013b, p. 1). Additionally, the Every Student Succeeds Act of 2015 reauthorized the Elementary Secondary Education Act which strengthens the view of including technology in the classroom as teachers teach their pedagogy. It is imperative that teachers are using technology in their classrooms, but this integration has to be intentional and geared towards improving student achievement.

At the state level in North Carolina, teachers in all grades are expected to incorporate computer skills throughout their subject area; therefore, technology integration into lessons should be seamless. The model that is used in North Carolina is the TPACK (Technological Pedagogical Content Knowledge) model. TPACK is a theory that came about from a seminal piece that was written by Mishra and Koehler (2006) titled Technological Pedagogical Content Knowledge: A Framework for Teacher Knowledge. Mishra and Koehler stated that their idea came from Shulman's (1987) work titled Those Who Understand: Knowledge Growth in Teaching. Shulman stated that 
teachers should not only teach their content but should also be able to teach using specific teaching methods. Shulman felt that teachers must use pedagogical content knowledge or PCK to teach their content to students. Mishra and Koehler, after 5 years of research, created a new framework that would be cognizant of the benefits of technology in the classroom. They felt that technology should be included into the pedagogical content knowledge for all teachers.

North Carolina State Board of Education (2017) stated, "There shall be a comprehensive State implementation plan for the use of funds from the State School Technology Fund and other sources to improve student performance in the public schools through the use of learning and instructional technologies" (p. 1); thus, schools are expected to use the funds that are afforded to them by the state to ensure that the TPACK model is followed in schools. The result of the use of technology is to ensure that, as North Carolina State Board of Education continued, "the use of technologies challenges State, federal, and local educational performance" (p. 1). The ultimate aim is to "effectively integrate technologies that are compatible with the standard course of study, the State assessment program, and related student data management" (North Carolina State Board of Education, 2017, p. 1).

Additionally, North Carolina teachers are expected, since they are employing the TPACK model, to create lesson plans that have activities that address both technology, and one or more content objectives (TPACK Online, 2012). By doing this, the ultimate aim is to connect learning for students; thus, North Carolina teachers are expected to use technology to foster learning in their classroom. North Carolina teachers, according to state law, must use technology to enhance the teaching and learning environment as well. The General Assembly of North Carolina (2013) in House Bill 23 stated, "the State 
Board of Education must develop and implement digital teaching and learning standards for teachers and school administrators" (p. 1). As a result, it is an expectation that teachers not only use technology in their classroom but also ensure the technology boosts student understanding of the pedagogy being taught.

Along with the TPACK theoretical framework that supported this research is the North Carolina digital learning competencies. The North Carolina digital learning competencies for students and teachers are informed by the International Society for Technology in Education (ISTE; North Carolina Department of Public Instruction, 2016). Classroom teachers and administrators must use digital learning competencies to improve pedagogical practices and to drive student learning in the classroom. The focus areas for digital learning competencies are leadership in digital learning, digital citizenship, digital content and instruction, and data and assessment. The digital learning competencies state that teachers must know and use the appropriate digital tools for instruction. Teachers are expected to model digital citizenship and support the creation of a positive school culture. Teachers are to use technology to make data more accessible, and they must meet the needs of a diverse learner population. Finally, teachers are expected to integrate digital teaching and learning pedagogies in their lessons. In a one-to-one learning environment, digital learning competencies can drive the implementation and sustainability of the initiative. Teachers and administrators are not only expected to use technology to enhance the teaching and learning environment, they are also expected to build a school culture that encourages a digital school culture.

Without a doubt, "our educational context has changed, and a new context demands new things" (Prensky, 2011, p. 2). Rather than try to insert knowledge into our students' brains, “today's teachers need to find ways to create $21^{\text {st }}$ century citizens who 
parrot less and think more" (Prensky, 2011, pp. 2-3); however, as teachers attempt to find ways to create a class environment that will teach students to be ready for the future, they need the support that will show them how to incorporate lessons that are technologically enhanced. In order for instruction to be effective, lessons must be designed to address the needs of each individual student (Conole \& Fill, 2005).

As we ask teachers to teach students who are referred to as digital natives and the net-generation, it is imperative that support be given to teachers in order to ensure they are able to incorporate technology seamlessly into their lessons. Without a doubt, we must also be cognizant that teachers were not taught in the way they are being asked to teach. All these terms are being used to highlight the significance and importance of new technologies within the lives of young people (Gibbons, 2007). When elementary school teachers use and model different forms of technologies, they actively engage their students and create a stimulating work environment (Kenney, 2011). Technology is definitely just a tool that can be used to restructure and redesign the classroom to produce an environment that promotes the development of higher order thinking skills (Kurt, Girgin, \& Odabasi, 2011); thus, the way in which education is approached is different in comparison to how the teachers were taught when they were in school.

Therefore, as school districts look at using more technology in lessons teachers are teaching, accommodations must be made to ensure that school teachers are able to model different forms of technology for students. "Unfortunately, even our younger 'Digital Native' teachers do not automatically know how to best use pedagogies which they didn't experience in their own education, to teach the students that sit in front of them" (Prensky, 2011, p. 19). Strategic, targeted professional development that is specific to the teacher's need could allow teachers to effectively teach their pedagogy 
utilizing technology which students are exposed to in society. One solution that has emerged for dealing with the increasing technology needs of students is to consider "the classroom of the future as one that we are building one step at a time" (Prensky, 2011, p. 1). Thus, it becomes a challenge for teachers who are in a school district that has a oneto-one program for students, yet they are unable to communicate effectively with the students they teach.

The third theoretical framework that supports this study is Bandura's (1977) selfefficacy theory. Bandura's self-efficacy theory adheres to the principle that people may engage in activities if they perceive that they are competent in those areas. Teachers may use technology more effectively if they perceive that they are competent in that area. Bandura is of the view that if an individual feels competent in a given activity, they may confidently implement and attempt to sustain the activity. In this case, if teachers feel confident in their technological ability, they may attempt to sustain a one-to-one computing initiative.

\section{Statement of the Problem}

The question in need of an answer is how can professional development and exposure of teachers to technology prior to implementation assist with sustaining a oneto-one computing initiative?

The cause of this problem is the easy access and influx of technology that improves daily. The ease with which one can have access to a mobile device has further served to compound this problem. Mobile devices oftentimes offer the same access a computer would provide. Many of our phones today are referred to as "hand held supercomputers that could do anything one could do on a laptop, fueled by vast digital media collections and app stores" (Birch, 2017, p. 1). The portion of young people who 
use technology is higher than the older population (Cheong \& Cheung, 2008; Dutton \& Helsper, 2007). Additionally, there are significant differences in how and why young people use these technologies and how effectively they use them (Livingston \& Helsper, 2008).

\section{Purpose of the Study}

The purpose of this study was to ascertain the impact of professional development on teacher instructional practices in order to sustain the one-to-one computing initiative at the high school level. It should be noted that sustain here means to look at ways to develop and sustain teamwork, in particular the standards and individual development that will serve to enhance teacher abilities to embrace technology in their classrooms (Hitt, 2011; Holcomb, Holmes, \& Connelly, 2009; Zucker \& Light, 2005). This study also acknowledges the fact that professional development will play a key role in this process. If a school district is willing to invest in one-to-one computing initiatives, it must want that investment to have a positive impact on student learning. This study discusses some of the instructional changes that must be considered in order to sustain one-to-one computing initiatives.

The time allotted for professional development for teachers prior to the implementation of one-to-one initiatives to students, the professional development that was afforded to teachers during implementation, and teacher perceptions of the worth of the professional development they were given were examined. This research provides data that were used to lay the foundation for what may be needed in order sustain one-toone computing initiatives as it relates to professional development for teachers.

\section{The Research Problem}

It was once thought that it was too expensive to integrate one-to-one computing 
initiatives in public schools; however, the purchase of these laptop devices is now more affordable, thus making implementation for one-to-one computing initiatives far more worthy of consideration (Greaves, Hayes, Wilson, Gialniak, \& Petersen, 2012).

Consequently, if school districts are going to invest the needed money into implementing a one-to-one computing initiative at their schools, "we must look at what teachers are doing in their classrooms, and how the laptops have had an influence on the teaching and learning that takes place" (Annable, 2013, p. 71). "Effective teaching is an outcome of preparing and continually training teachers and leaders to guide the type of learning that we want in schools" (USDOE, 2010, p. 5).

If students love technology, it is thought that they should be easy to teach using this technology; however, "adapting to this new context of change, variability and uncertainty is the biggest challenge we are now facing — as educators and as people" (Prensky, 2011, p. 1). The problem is that putting a laptop into a student's hand does not equate to teaching the lesson. School districts, if they plan on implementing and ultimately sustaining one-to-one computing initiatives, must look at the needs of teachers, so school districts can best facilitate the implementation and ultimately the sustainability of the computing initiative. "The changes toward the way today's students learn best must drive the technology we acquire and use, rather than having our future classrooms be driven by any technology's feature set, bandwidth, availability or price" (Prensky, 2011, p. 3).

It has been recommended that future research involving one-to-one computing initiatives include the examination of teacher practices before laptop implementation along with any change that occurred after laptop implementation (Annable, 2103). Tweed (2013) echoed the need for conducting research on pre- and post-laptop 
implementation effects on classroom instruction. Tweed also talked about the need for further research on technology based professional development and the impact it had on teacher instruction. "There were insufficient studies to reach conclusions about the following issues related to professional development" (Sell, Cornelius-White, Chang, McLean, \& Roworth., 2012, p. 31).

\section{Background and Justification}

Prensky (2011), Tapscott (2009), Howe and Strauss (2000) have all stated in their various writings that students of today learn in a different way when compared with past generations. "It is claimed that today's generation of young people have been immersed in a world infused with networked and digital technologies, [as a result,] they think differently, they learn differently... and have different expectations about life and learning" (Jones \& Shao, 2011, p. 3). Of note too is that "interactive technology - in this case, video games - can change the brain, and in particular, the way we perceive things" (Tapscott, 2009, p. 98).

It is important that "technology is used for some practical purpose, and not for the sake of using technology ... when people focus too much on technology, they lose sight of the true purpose of technology, which is to facilitate learning in the classroom" (Oblinger \& Oblinger, 2005, pp. 4.9-4.10); therefore, "faculty and administrators today

must not only establish the infrastructure for learning technology in the classroom ... but it will also take great effort ... to learn and use technology effectively" (Oblinger \& Oblinger, 2005, p. 4.10).

As school districts adapt to an ever-changing society, it is important to ensure that students are being exposed to the technology to which they innately gravitate. In order to prepare teachers for the environment in which they must now work, it becomes important 
that teachers are given the professional support that will serve to assist with honing their craft.

It is inevitable ... that change would finally come to our young people's education as well, and it has. But there is a huge paradox for educators: the place where the biggest educational changes have come is not our schools; it is everywhere else but our schools. (Prensky, 2011, p. 1)

"The educational establishment is utterly confused about what to do about the impact of technology on learning" (Palfrey \& Gasser, 2008, p. 238); thus, "education has to change because there has been a generational shift caused by a process of technological change" (Jones \& Shao, 2011, p. 8). As was previously stated, in order to prepare teachers for the environment in which they now must work, it becomes important that teachers are given the professional support that will serve to assist with honing their craft. This will also give them the tools to use technology in the appropriate way that will serve to enhance the teaching and learning environment they provide daily for students.

\section{Deficiencies in the Evidence}

The population focused on for this study was teachers at the secondary level. Also, the teachers studied were teachers at the high school level who already had a oneto-one computing initiative implemented at their school. The following are limitations of this study:

- There were no data for teacher perceptions of the quality of professional development before implementation.

- The study was limited to the 9-12 grade school level.

- The three schools in this study are located in similar areas in the state.

- Two of the three schools that were studied are nontraditional high schools. 
- There was no comparison with other nontraditional middle and high school from a different state or from another region in the state.

- There was no survey of teachers prior to the implementation of the one-to-one computing initiative at their school, rather teachers reflected on what their lessons were like prior to the implementation on the one-to-one computing initiative.

- The study was conducted on a sample of the teacher population within the school district.

- The assumption was made that all participants would respond accurately concerning the professional development questions on the survey.

- The researcher is an administrator in one of the school district that participated in this study.

\section{Research Questions}

The following research questions guided this study:

1. What are teacher perceptions of the quality of professional development after the implementation of a one-to-one computing initiative?

2. What are teacher perceptions of the time spent on professional development and its value for the teaching of their lessons?

3. What are teacher perceptions of the value of the time allotted to teachers to have access to their devices prior to students having access to the similar device?

\section{Definition of Terms}

The following key terms are defined:

One-to-one computing initiative. A learning initiative by which students are 
given a computing device for use during learning, be it at school or outside of regular school hours (Bebell \& O’Dwyer, 2010; Castle, 2012).

Digital natives. A person born or brought up during the age of digital technology and therefore familiar with computers and the Internet from an early age (Prensky, 2011, p. 1).

Digital immigrants. A person born or brought up before the widespread use of digital technology.

Sustain. Sustainability does not simply mean whether something will last. It addresses how particular "initiatives can be developed without compromising the development of others in the environment now or in the future" (Hargreaves \& Fink, 2006, p. 30).

Professional development. Professional development involves workshops, courses, programs, and related activities that are designed presumably to provide teachers with new ideas, skills, and competencies necessary for improvement in the classroom (Fullan, 2007).

Mindset. The established set of attitudes held by someone (dictionary.com).

\section{Summary}

The one-to-one computing initiative is changing the manner in which students are instructed in the classroom (Storz \& Hoffman, 2013). Effective one-to-one computing initiatives require a student-centered rather than a teacher-centered approach to instruction (Bebell \& Kay, 2010). This is a paradigm shift for many teachers who are accustomed to teaching via lectures. Teachers will have to adapt a new mindset in order to cater to the needs of their students.

Rather than trying to insert knowledge into our kids' heads, as in the past (and 
then to measure how much of it got there), today's teachers need to find ways to create $21^{\text {st }}$ century citizens (and workers) who parrot less and think more. This requires fully integrating into our teaching "meta" skills like critical thinking, problem solving, video and programming, just as we now integrate reading and writing. (Prensky, 2011, p. 3)

Teachers have been exposed in some form to ways technology can be incorporated into their lessons. Some have made an attempt to incorporate technology in a way that they believe can work. "Yet even as teachers become motivated to adapt and move forward, it is not always obvious how to change old habits" (Prensky, 2011, p. 3). This is where intentional professional development will come to the fore.

In Chapter 2, a review of literature that highlights the important research on professional development necessary to sustain a one-to-one computer initiative is discussed. It is considered through the lens of the important role professional development plays in guiding teaching and learning behaviors of teachers. 


\section{Chapter 2: Literature Review}

"Not only does technology offer a variety of instructional options to teachers it also motivates students who are accustomed to electronic devices in their everyday lives" (Borthwick \& Pierson, 2008, p. 11). "It is unclear that students will have access to teachers who know how to use that technology well to support 21 st-century learning and teaching” (Lawless \& Pellegrino, 2007, p. 578). Without a doubt, “America is caught in the grip of a crisis in education that threatens the ability of an entire generation of young Americans to achieve success in life and work" (Apple Classrooms of Tomorrow-Today [ACOT2], 2008, p. 4). In response to this, "one-to-one computing initiatives have emerged as one of the most common educational reforms" (Bebell \& Kay, 2010, p. 5).

The Texas legislature in 2003 created the Technology Immersion Pilot which led to the immersing of Texas public schools into technology. A study was conducted by Shapely, Sheehan, Maloney, and Caranikas-Walker (2009) of 21 middle schools in Texas in order to examine the success of the technology immersion model that was implemented in 2003. They found that "teachers cited the lack of preparation was a major barrier to effective implementation of the computing initiatives" (Shapely et al., 2009, p. 45). "The authors of Project Red listed that giving the devices to teachers, and later to students, ensures that teachers maintain control over their own learning and can develop integrative practices for teaching on a developmental basis" (Greaves, Hayes, Wilson, Gialniak, \& Petersen, 2010, p. 43).

ACOT2 "is a collaborative effort with the education community to identify the essential design principles for the 21st century high school” (ACOT2, 2008, p. 4). ACOT2 (2008) "assumes as its starting point that time-honored yet outmoded approaches to education and education reform must be replaced with new and creative ways of 
thinking about designing learning environments for this generation of students" (p. 4). As a result, ACOT2 (2008) believed that there are several design principles that must be looked at in order to maintain a $21^{\text {st }}$ century high school.

- Understanding of 21st century skills and outcomes. "Establishes that as a baseline that educators, students, and parents must be well versed in the $21 \mathrm{st}$ century skills that need to acquire to be successful" (ACOT2, 2008, p. 4).

- Relevant and applied curriculum. "Curriculum should apply to students' current and future lives and leverage power of the Web 2.0 and other ubiquitous technologies" (ACOT2, 2008, p. 4).

- A culture of innovation and creativity. "Schools should create a culture that supports and reinforces innovation for student learning and leverages the creativity and ingenuity of every adult and student in their environment to solve their unique problem" (ACOT2, 2008, p. 5). It should also be noted that "the teaching and learning environment should generate the continuous development of those skills" (ACOT2, 2008, p. 5).

- Ubiquitous access to technology.

Students and educators need 24 by 7 access to information, resources, and technologies that engage and empower them to do background research, information and resource gathering, and data analysis, to publish with multiple media types to wide and varied audiences, to communicate with peers and experts, and to gain experience and expertise in collaborative work. (ACOT2, 2008, p. 5)

"It is not really about the laptops. It is about what the laptops enable in terms of new ways of teaching and learning” (Dunleavy, Dexter, \& Heinecke, 2007, p. 451). One 
thing that should be taken into account is the fact that "technology is just a tool; unless a teacher is shown how to use it effectively, then technology use will not lead to changes in teaching and learning" (Annable, 2013, p. 167).

In North Carolina, educators are expected to use the TPACK theoretical framework that should assist teachers in being able to use technology effectively in their classroom. The three content areas to consider are technology, pedagogy, and content knowledge. Figure 1 illustrates the four areas that are created in Mishra and Koehler's (2006) framework.

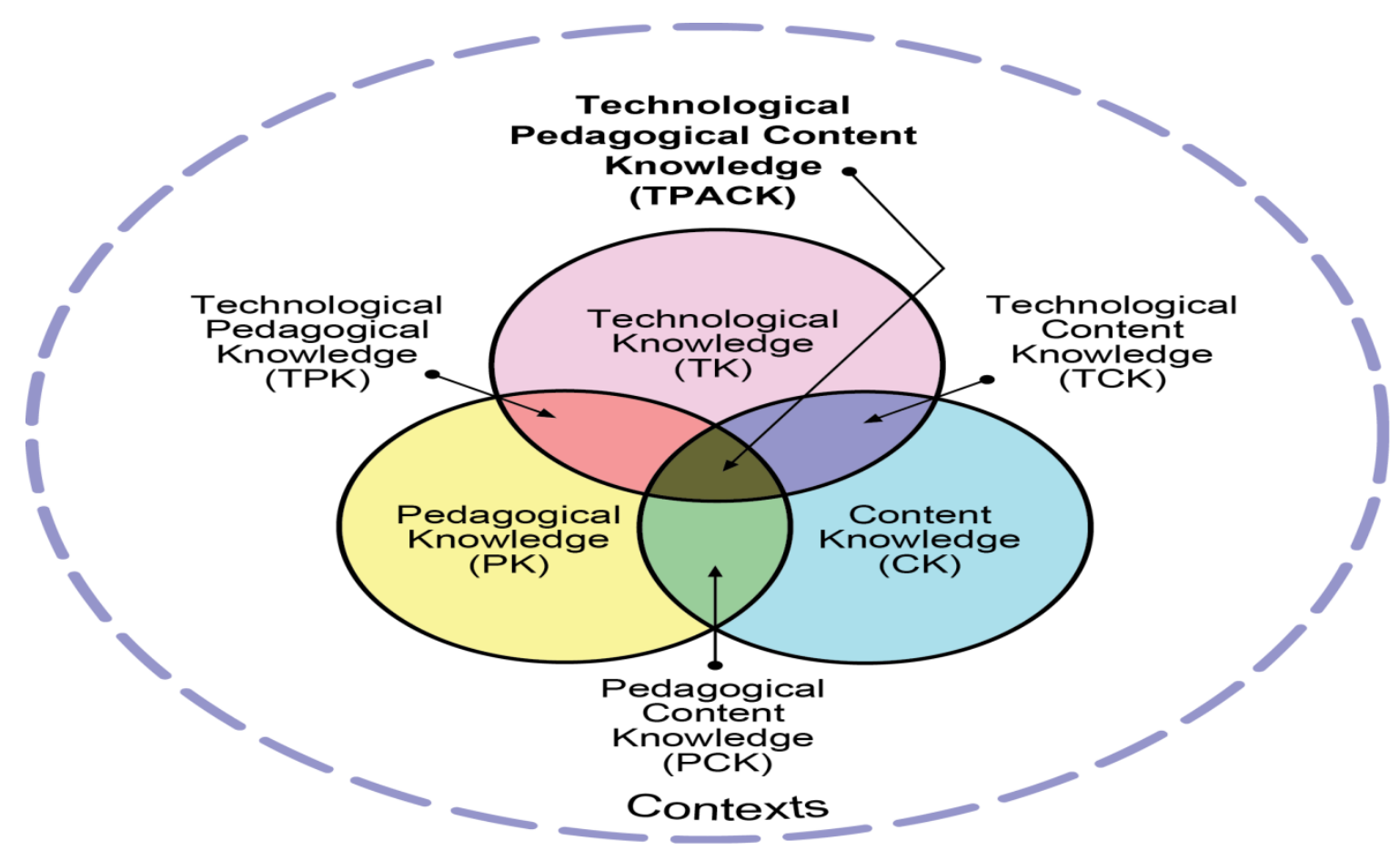

Figure 1. Technological Pedagogical Content Knowledge.

The TPACK model illustrated in Figure 1 shows how technology influences a teacher's content. Figure 1 also illustrates how pedagogy and technology influence each other and that it is important to incorporate technology into the classroom. Finally, all three sets of knowledge outlined in Figure 1 influence each other. The TPACK 
framework supports this study for it stresses the coming together of all the components as they overlap. It is imperative that teachers are able to use technology, know their content, and interweave pedagogical knowledge seamlessly as they teach their content. If there is to be an effective teaching environment, a class lesson must have all components. Mishra and Koehler (2006) stated that technology should not be seen as a separate component in the classroom, it should be integrated in the lesson so students can learn more effectively. PBS (2013) conducted an online survey of K-12 teachers and cited that $74 \%$ of educators believe that technology gives them the ability to reinforce and expand their content. Raulston and Wright (2010) concluded that a one-to-one computing initiative that is complemented with effective professional development could be beneficial to students as they learn in the $21^{\text {st }}$ century. This research looked at the quality of the professional development that was afforded to teachers prior to and during implementation of a one-to-one computing initiative. Additionally, USDOE (2010) indicated that "episodic and ineffective" (p. 5) professional development must be replaced by learning opportunities that are "collaborative, coherent, and continuous" (p. XII). "Not only do teachers need to become familiar with hardware and software, but they need time to review available resources that would be relevant to their classroom" (Greaves et al., 2010). "Teachers will be more likely to use technology in their classrooms if they feel comfortable and confident with it, and if they see a purpose to use it" (Annable, 2013, p. 174).

According to ISTE, who released the National Education Technology Standards for Teachers (NETS-T), teachers who continuously improve their professional practice, model lifelong learning, and exhibit leadership in their school and professional community felt comfortable with technological tools. Teachers also "contributed to the 
effectiveness, vitality, and self-renewal of the teaching profession of their school and community" (USDOE, 2010, pp. 1-2).

Teachers who have positive self-efficacy can be effective users of technology and can assist with sustaining of a one-to-one computing initiative. Bandura's (1977) selfefficacy theory discusses four components: performance accomplishments, vicarious experience, social persuasion, and physiological and emotional states. Performance accomplishments are based on an individual's personal accomplishments; therefore, a teacher who has not used technology in their classroom may not have self-efficacy that is based on personal accomplishments. Vicarious experience refers to what is observed as others perform an activity successfully. Teachers who have not been exposed to professional development that shows how to effectively use technology for their content or have not seen others in their department using technology effectively may not have self-efficacy that is based on vicarious experiences. Social persuasion belief is based on activities that lead people into believing they can successfully complete certain tasks. Teachers who do not have coaches who can give them evaluative feedback based on what the teacher has done in regard to technology use may not develop self-efficacy that is based on social persuasion. Physiological and emotional belief states that an individual can influence their self-efficacy judgments when it comes to certain tasks. A teacher who does not have a physiological or emotional state that can positively influence their ability to incorporate technology into their classroom may not display this level of self-efficacy. As a result, teachers may not want to use technology in their classroom, even though TPACK, legislators, and school districts may stress the incorporation of technology with their content. They may not perceive themselves to be competent in these areas.

Effective teaching is the result of continual development that is designed to 
inspire teachers and encourage buy-in for the district's technology program (Shapely et al., 2009). As stated by USDOE (2010), "the best form of technology professional development [is one that allows] teachers to experience technology firsthand" (p. 5). In order for professional development to be of high quality, it must

provide long durations, have follow up sessions, provide access to new technologies for teaching and learning, actively engage teachers in meaningful and relevant activities for their individual contexts, promote peer collaboration and community building, and have a clearly articulated common vision for student achievement. (Lawless \& Pellegrino, 2007, p. 579)

Therefore, it is imperative that effective school leaders provide ongoing, embedded professional development in order to ensure best practices for new century education. Federal, state, and local policies should support the expectation that principals will actively seek, develop, and implement robust professional learning for themselves and their teachers.

(Greaves et al., 2010, p. 52)

Professional development should include various experiences that not only include the familiarizing of oneself with hardware and software but also focuses on ongoing professional development for teachers. This will assist teachers to "learn through the on-the-job application of best practices, reflection with peers, and collaboration on how to implement theories in the classroom" (Greaves et al., 2010, p. 52). 


\section{Impact of TPACK Professional Development on Teacher Self-Efficacy with Technology}

It is important that teachers have pedagogical and technological knowledge of their content. In a study conducted by Foulger, Wetzel, Lindsey, Buss, and Pasquel (2016) of the integration of technology at Mary Lou Fulton College, they concluded that the use of TPACK was effective. Teachers at the college were exposed to professional development that assisted them to use TPACK in their classroom. Foulger et al. also stated that teacher self-efficacy improved since they were able to feel competent in their ability to use technology in their classes.

Corkin, Ekmekci, White, and Fisher (2016) surveyed 80 K-12 mathematics teachers from urban school districts in Florida before and after a 3-week professional development program about TPACK. They concluded that "not only do teachers need knowledge of how to incorporate technology for instruction, but they also need to believe that they have the ability to use technology effectively" (Corkin et al., 2016, p. 101). Corkin et al. stated that teachers wanted to use technology in their classrooms, but they wanted to develop self-efficacy about its use in order to confidently incorporate technology into their lessons. Corkin et al. also stated that modeling for teachers is needed in order for them to incorporate technology into their lessons.

Knapp (2017) conducted a case study that involved the documentation of the experience of three teachers who participated in "TPACK focused professional development workshops that were designed to improve their understanding of how to effectively use technology to teach Social Studies and whether participation in the workshop influenced teachers' technology efficacy" (p. iii). Knapp indicated that the teachers studied believed that "seeing technology modeled in meaningful applications 
paired with the opportunity to practice or become a student was very useful to them" (p. 88). Knapp went on to state that teachers stated that the professional development that they had with TPACK assisted them to be able to improve their self-efficacy as it relates to technology integration in their classes. This study also highlighted Bandura's (1977) theory of self-efficacy, in particular the importance of modeling technology use in the classroom for teachers.

\section{Learning to Use the Hardware}

Hogue (2013) examined "scholarly literature on the adoption of technology in education in order to determine the key considerations for designing and evaluating professional development to support the use of technologies such as iPads for higher learning" (p. 25). One of the conclusions of the examination was that "scholars, who have studied the adoption of technology in educational settings, believe that professional development is necessary for its successful adoption" (Hogue, 2013, p. 25).

Calendar time (that is, a period of elapsed time as opposed to a specified number of hours) must be allowed in order for an individual to absorb information about the new technology and reflect upon how it can be adapted to his or her workflow. (Hogue, 2013, p. 30)

Similarly, Higgins and Russell (2003), who conducted a survey into the types of professional development teachers thought were beneficial to integrating technology in the classroom, reported that the majority of the high school teachers in their study indicated that basic professional development designed to teach teachers to manage their computers was not necessary. They found that teachers preferred to be taught how to use the devices in their lessons. Penuel (2006), who synthesized the findings from 30 separate studies of one-to-one initiatives which included Henrico County in Virginia, 
Cobb County in Georgia, and the SRI International Researchers who were under contract with the USDOE, went on to state that teachers reported that their technology professional development sessions typically focused on the procedural use of the software. On the other hand, learning how to effectively use the hardware for classroom instruction was more critical (Penuel, 2006).

Today nearly two billion cell phones are in use around the world, and access to the Internet is rapidly increasing in schools, homes, community centers, and Internet cafés worldwide. This is providing even more opportunities to learn and develop skills. At the same time, the potential for information overload, distraction, and analysis paralysis when facing demands for attention from too many sources — ranging from well-informed and reliable to woefully uninformed and even deliberately misleading - is also high. Learning to manage our digital power tools and to apply the critical thinking and information literacy skills needed to put all this information to good use is a clear challenge for the $21 \mathrm{st}$ century. (Trilling \& Fadel, 2009, p. 17)

Therefore, it becomes critical that teachers are able to teach students how to “acquire and apply new knowledge" (Trilling \& Fadel, 2009, p. 9). Also, without any clear leadership concerning "the management and oversight ... teacher and student technology use will be limited" (Bebell \& Kay, 2010, p. 50), thus "teacher preparation through quality professional development can be statistically significant" (Shapely et al., 2009, p. 33). Research by Drayton, Falk, Stroud, Hobbs, and Hammerman (2010) indicated that "a lack of professional development, especially in the form of teacher collaboration to develop best practices within a school, becomes a barrier to effective integration of computer and Web resources in the classroom" (p. 41). There are a lot of 
factors that would affect the sustainability of one-to-one computing initiatives; however, a number of teachers changed the practices to accommodate the opportunities of increased technology access (Bebell \& Kay, 2010; Drayton et al., 2010; Shapely et al., 2009; Suhr, Hernandez, Grimes, \& Warschauer, 2010).

Eristi, Kurt, and Dindar (2012) conducted a study of a sample of 21 teachers who teach at Tepebasi Resali Benli Elementary in Eskisehir, Turkey. In their study, they wanted to ascertain teacher views about effective use of technology in classrooms. They found that "learning could be said to be permanent when individuals learn in environments similar to real-life situations or when they learn by actual application and experience" (Eristi et al., 2012, p. 21). Eristi et al. also stated that "generally, teachers demonstrated self-criticism regarding technology use and attributed ineffective use of technology to their own efficacies" (p. 36). Eristi et al. went on to state that teachers found technology is always changing, and they need to participate in professional development that would help them improve their efficacies and be able to utilize technology effectively in their classrooms.

\section{Learning to Use the Software}

Eristi et al. (2012) found in their research that "the teachers participating in the study emphasized that most of their students were better than them in using technological tools or environments" (p. 39). Therefore, adequate support needs to be provided to teachers through professional development, so they can use digital resources appropriately in their classrooms. Nadelson, Bennett, Gwilliam, Howlett, and Oswalt (2013), in an effort "to understand the implications of the evolving landscape of technology in education, examined the responses of 52 preservice teachers to determine their confidence with, perceptions of, and intentions for using instructional technology to 
teach and learn" (p. 77).

Nadelson et al. (2013) found in their study that technological enhancements require students to access information and communicate using technology; thus, skills must be fostered through the use of technology in education (USDOE, 2010). Furthermore, digital natives, or those students who have grown up immersed in technology, desire and demand this type of technological interfacing as part of the learning experience (Greaves et al., 2012). Researchers have identified a number of factors that may influence a teacher's likelihood to integrate technology into instruction (Nadelson et al., 2013).

Miranda and Russell (2011) reported that the strongest predictors of classroom technology use (in descending order of influence) are (a) a teacher's beliefs about the potential benefits, (b) a teacher's experience with technology, and (c) a teacher's perceived pressure to use technology. Explicit instruction and more experience with a wider range of instructional technologies may be critical to expanding the number and forms of technology teachers consider and use in their instruction. As a result, professional development will be fundamental to the sustaining of one-to-one initiatives so it can be ensured that teachers are given the support they need in order to use technology effectively in their lessons.

\section{Time Spent on Professional Development for One-to-One Computing Initiative}

It is imperative that "professional development prior to implementation, address the dual roles of teachers both as technicians, as well as intellectuals developing teaching innovations" (Gulamhussein, 2013a, p. 7). In a study that focused on professional development research, "1,300 studies were analyzed to determine what forms of professional development impacted student achievement. It was found that for 
"professional development to be effective the program had to be lengthy and intensive" (Gulamhussein, 2013b, p. 1). It is also important that professional development is offered prior to one-to-one initiative implementation and that it be "supported during and after implementation in order to ensure that teachers effectively transfer information taught during professional development into the classroom” (Gulamhussein, 2013b, p. 1).

In a study by Rolf Blank and Nina de las Alas from 2006 to 2008, they focused on teachers in public elementary and secondary schools who participated in professional development to improve their teaching of math and science; and they found that in order to improve teacher quality, there had to be "ongoing professional development if efforts to improve the quality and performance of our public schools are to be actualized" (Blank \& De las Alas, 2010, p. 1). As Bebell and Kay (2010) stated, "teachers ultimately control the amount of technology integration that occurs within their classroom in a one to one computing initiative" (p. 6); therefore, "teacher learning via professional development is the linchpin between present day and new academic goals" (Gulamhussein, 2013a, p. 9).

Since the 1980s in South Korea, policy makers expect teachers to incorporate Information and Communications Technology (ICT) into their classrooms. As a result, the "teachers use of technology in their classrooms had improved dramatically in the last 2 decades, however, its use is not widespread and consistent" (Shin, Han, \& Kim, 2014, p. 11). As a result, Shin et al. (2014) conducted research in the South Korean context to see if the pressure by ICT has impacted their use of technology in the classroom or if they responded more favorably to the incorporation of technology into their classroom due to administrative support and professional development. A total of 661 in service teachers from 31 elementary schools in South Korea participated in their study. Shin et al. found that "overall, evidence supporting the results of extant research exists, indicating that 
teachers' personalities and their environment affect their use of technology in the classroom" (p. 18). They also stated that teachers were of the belief that simply mandating the use of technology was not sufficient, and they needed time to be spent on professional development as well. "It is not really about the technology. It is about what the laptops enable in terms of new ways of teaching and learning" (Dunleavy et al., 2007, p. 451).

Raulston and Wright (2010) also conducted a study to analyze teacher perceptions, attitudes, and instructional impact from a teacher laptop initiative that involved professional development for teachers prior to the deployment of laptops to students. Their study occurred during the 2007-2008 school year in one southeastern urban school system in the United States. The school system was composed of seven schools and served 6,000 students with a population of 400 teachers. Raulston and Wright found that "in order for teachers to prepare students for the 21st century, administrators must equip educators with the knowledge of how to integrate 21 st century skills into their classrooms" (p. 7). Raulston and Wright noted that because teachers were given a year of professional development prior to the computing devices being given to students, "it was evident that teachers believed that a laptop initiative coupled with professional development for them prior to and during implementation of a one-to-one computing initiative can help prepare students for the 21st century" (p. 7). It is imperative that teachers be given the tools and professional development support in order for implementation and sustainability of a one-to-one computing initiative to lead to improved quality of work from students (Raulston \& Wright, 2010). 


\section{Time Allotted for Teacher Access to Computing Devices}

ACOT2 (2008) recommended, "educators, students, and parents need to be well versed in the 21 st century skills that students need to be successful" (p. 4). As a result, the best form of technology professional development is one that allows teachers to experience technology firsthand (USDOE, 2010). Raulston and Wright (2010) highlighted that teachers found it beneficial that they were given time to access their laptops prior to student deployment. Along with having access to their laptops, "there were a number of laptop trainers who were chosen based on the faculty ratio at each school" (Raulston \& Wright, 2010, p. 2). It was also felt by teachers that "having the laptops prior to student deployment enabled them to spend more time with a device since they were able to carry the device home, and immerse themselves into learning to use their device" (Raulston \& Wright, 2010, p. 5).

The "introduction of one-to-one computing initiatives in a school places new demands on and affords new opportunities to teachers" (Storz \& Hoffman, 2013, p. 3). It was evident to Storz and Hoffman (2013) as they focused on a Midwestern urban middle school that "teachers wanted more emphasis on how to use the computer in their teaching, especially in their own subject" (p. 13). Some of the teachers in the study had an aptitude about the various ways to use technology in the classroom (Storz \& Hoffman, 2013). On the other hand, "many teachers felt that it would have been great if professional development had been able to get together a couple of months before the students had gotten their computers" (Storz \& Hoffman, 2013, p. 13). Teachers were also of the belief that it would have also been beneficial if they had "access to their laptops prior to students getting their devices as well” (Storz \& Hoffman, 2013, p. 14).

Majeski (2013) examined middle school teacher and principal perspectives as 
they relate to the use of technology in the classroom and schools. He found that "there needed to be greater access to laptops prior to the using of the technology in their schools" (Majeski, 2013, p. 56). Overall, teachers and principals were of the opinion that prior to them being expected to implement technology in their classrooms and schools, there needed to be more time given to teachers so they could become familiar with the technology. "It is important that teachers engage with the technology prior to them being asked to incorporate the technology in their classrooms with students" (Gulamhussein, 2013b, p. 1).

\section{Purpose Statement}

The purpose of this study was to ascertain teacher perceptions of the impact of professional development on teacher instructional practices in order to sustain the one-toone laptop initiative at the high school level. It should be noted that sustain here means to look at ways to develop and sustain the initiative, in particular the standards and individual development that will serve to enhance teacher abilities to maximize the use of technology in the classroom through continued professional development (Fullan, 2002). The study acknowledges the fact that professional development will play a key role in the sustainment of a one-to-one initiative. It is imperative that laptops not only be distributed to teachers prior to implementation; but as this study will discuss, it is also important that quality professional development that builds on the use of the laptops be maintained during implementation in order to build the sustainability of an effective one-to-one computing initiative. If a school district is willing to invest in one-to-one computing initiatives, it may want to consider continuous quality professional development for its teachers after implementation.

In a study of one-to-one programs conducted in five middle schools in western 
Massachusetts, Bebell and Kay (2010) found, "it is impossible to overstate the power of individual teachers in the success or failure of one to one computing" (p. 47). They reported that the lack of buy-in and teacher knowledge was key. The study found the schools struggled so much with incorporating laptops that after 3 years, students were not using technology any more than schools that did not have laptops (Bebell \& Kay, 2010). Greaves et al.'s (2010) study of 997 schools across the United States identified nine factors that, if present, appear to contribute to higher levels of achievement in schools that have adopted one-to-one programs. The top three factors were as follows:

1. Ensuring uniform integration of technology in every class.

2. Providing time for teacher learning and collaboration (at least monthly).

3. Using technology daily for student online collaboration and cooperative learning (Greaves et al., 2010).

Interestingly, Marzano and Waters (2009) talked about the fact that ensuring uniform integration of technology in every class implies a district has a clearly articulated, district-wide approach to instruction - a key trait of high-performing districts as well. This study examined the role of professional development in the sustainability of a one-to-one initiative. Therefore, the data that were used laid the foundation for what may be needed in order to sustain one-to-one initiatives as it relates to professional development for teachers.

\section{Research Questions}

The following research questions guided this study:

1. What are teacher perceptions of the quality of professional development after the implementation of a one-to-one computing initiative?

2. What are teacher perceptions of the time spent on professional development 
and its value for the teaching of their lessons?

3. What are teacher perceptions of the value of the time allotted to teachers to have access to their devices prior to students having access to the similar device?

\section{Summary}

The increased availability of technology in today's world is vast, varied, and improves every day. One-to-one computing initiatives are becoming an option that many school districts are moving towards (Bebell \& O’Dwyer, 2010). The problem then becomes how we can sustain the one-to-one computing initiative. The responses were numerous, but the focus of this study was to ascertain the quality of professional development for teachers; the aim being to ensure teachers were aware of the various ways technology can be used to enhance their lessons.

Chapter 3 provides a methodology for this research. A general overview of the overall population of study and the sampling methods for determining participation in the study are provided. 


\section{Chapter 3: Methodology}

\section{Introduction}

The primary purpose of this study was to examine the impact of quality of professional development on the sustainability of a one-to-one computing initiative. As a result, a qualitative design was utilized to examine the one-to-one computing initiative that was currently being used at three nontraditional high schools in North Carolina. Each of the three schools has implemented a one-to-one computing initiative, which is a learning initiative by which students are given a computing device for use during learning, be it at school or outside of regular school hours (Bebell \& O’Dwyer, 2010; Castle, 2012). The methodology of this study includes (a) the research design, (b) data collection and procedures, (c) participants, (d) analytical methods, and (e) the roles of the researcher.

\section{Purpose and Overview}

The purpose of this qualitative study was to ascertain teacher perceptions of the impact of professional development and access time to the device prior to implementation in order to sustain the one-to-one computing initiatives at the high school level. The aim was to ascertain any trends based on the information that was collected from the survey. It was important to study any trends that emerged when the survey was completed, for this "may help us to understand social phenomena in natural (rather than experimental) settings, giving due emphasis to the meanings, experiences and views of the participants" (Pope \& Mays, 1995, p. 311). Schreier (2012) stated, "researchers who use Qualitative Content Analysis (QCA) frequently assume that there is a reality 'out there', and that this reality is represented in the material under analysis" (p. 47); thus, a qualitative methodology was used since the purpose of this study was to ascertain teacher 
perceptions of the impact of professional development on teacher instructional practices in order to sustain the one-to-one computing initiatives at the high school level. Teacher perceptions of the professional development that was afforded to them during the one-toone computing initiative implementation, their perceptions of the time spent on professional development and its value for the teaching of lessons, and their perceptions of the time allotted to teachers to have access to their devices prior to students having access to a similar device were examined. The aim of the study was to examine how the experiences of the teachers were impacting the sustainability of the one-to-one computing initiative in their school district. The research aimed to see what role professional development played on the instructional practices of the teachers as well.

According to Weber (2012), qualitative research goes beyond word counts to “classifying large amounts of text into an efficient number of categories that represent similar themes" (p. 50). Schreier (2012) said, "the process of qualitative content analysis can inherently provide validity" (p. 133). In this study, the unit of analysis is the themes that arose based on participant responses to the survey questions; thus, responses generated by the survey required the researcher to "interpret meaning" (Schreier, 2012, p. 133). In this research design, three nontraditional high schools in North Carolina that have implemented a one-to-one computing initiative were examined. This study utilized an online survey and involved interviews that provided an in-depth study of the one-toone computing environment in the three high schools.

Greaves et al. (2010) stated their desire to contribute to the reengineering of education through research and through sharing compelling stories of transformation as it relates to Project RED. According to Project RED, which is a national research and advocacy plan to investigate how technology can help us to reengineer our education 
system, "it is well established that educators need consistent, ongoing professional development in pedagogy, best practices, research, content, curriculum, and the personalization of instruction" (Greaves et al., 2010, p. 52).

As a result, this study investigated the impact of time spent to prepare teachers for one-to-one computing initiatives, the time allotted to teachers with their laptops prior to student roll out, and how teachers value the professional development they were afforded prior to roll out. The focus was on the types of professional development teachers were exposed to during their implementation and continued one-to-one program that aided in their ability to maintain the use of their computing device as a part of their pedagogy. All participants completed an online survey (Appendix A). This online survey was based on a survey done by Damian Bebell and Brad Hanson. Permission was given by both to use parts of their survey (see Appendices B and C); thus, three principals and six teachers, two from each of the three different high schools, were asked to complete face-to-face interviews. The aim of the researcher was to interview a novice and/or intermediate teacher and an advanced and/or expert technology competent teacher at each school. Teachers were asked to identify their technology competency level on the 17-item survey. It was from these responses that the two teachers in the categories stated were conveniently selected to participate in the interviews.

Each interview could last for 20-25 minutes. An email about survey participation was sent out to all respondents (Appendix D). There were also scripted questions which were based on this study's research questions and the survey questions teachers (Appendix E) and principals (Appendix F) were asked during their interviews. Respondents were emailed the survey participation request (Appendix G) that had the link for the survey if they chose to complete it. Respondents who indicated on their 
survey that they would like to participate in an interview were asked to sign an interview participation informed consent form as well (Appendix H). This study utilized an online survey and interviews in order to provide a rich and in-depth study of the sustainability of one-to-one computing initiatives that the three nontraditional high schools have implemented. All teachers and administrators were asked to complete the online survey; however, only three principals and six teachers, two from each school, participated in the interviews. Also, a professional transcriptionist transcribed the interviews.

This study was conducted in the fall of 2018 in North Carolina. The study involved teachers at three nontraditional high schools who had already implemented oneto-one computing initiatives. The Impact of Professional Development on the Sustainability of One-to-one Initiative Survey (Appendix A) was used to answer the research questions that are stated in this study. The survey examined the demographics at each school, the length of time the teachers had the laptops prior to implementation with students, the length of time teachers were exposed to professional development, and their perceptions of the professional development they were given. It is important to also know how often teachers used technology in their classrooms.

\section{Data and Collection Procedures}

Written permission was sought from the superintendents of the three school districts. Principals and teachers at the schools were contacted via email with a link to the survey (Appendix G) and given a 3-week time period in which to complete the survey. The survey was administered using Survey Monkey. Upon the conclusion of the 3-week period, findings were analyzed.

The teacher participants within this study were administered a one-to-one Computing Survey (see Appendix A) in the fall of 2018. Due to the small population of 
teachers at the schools, all teachers at the schools were sent the request to participate in the survey. The survey instrument is a combination of questions that were used by Dr. Bradley Hanson (2014), Superintendent of Monett R-1 school district in Missouri, for his research and the teacher survey developed for Berkshire Wireless Learning Initiative by Bebell and Kay (2010) that was created by the Technology and Assessment Study Collaboration from Boston College with the leadership of Dr. Damian Bebell. The researcher received written permission from both Boston College via Dr. Damain Bebell and Dr. Bradley Hanson to use the combined survey instrument that was already validated. The one-to-one Computing Implementation Survey was created based on the "current literature surrounding the types of instructional change expected within one to one computing initiatives along with the suggested models for professional development needed for effective implementation of these initiatives" (Bebell \& Kay, 2010, p. 6; Greaves et al., 2010; Sell et al., 2012).

The survey consists of 18 questions. The first question asks participants to identify the school district in which they are employed. Question 2 and 3 asks participants to indicate the years they have taught, and their competency level with technology respectively. Question 4 asks teachers to state the length of time that they had access to a computing device that is similar to the one that students are using in the oneto-one initiative.

Question 5 on the survey is to determine teacher perceptions of four different types of professional development they may have experienced and to ascertain the value it had on their pedagogy. The remaining 10 questions focused on teacher practices as they relate to multiple instructional practices.

The next step of the process was to conduct nine interviews since there were a 
total of six teachers and three principals participating in the interview process. Teachers were randomly selected to participate in the interview process from among those who volunteered by using convenience sampling. The interview questions are in Appendix E and F. The interview questions asked about the positives and negatives as they relate to the one-to-one computing initiatives that are evident at all schools in this study. The interviews were recorded and transcribed for accuracy. The information gained from the interviews served to answer all three research questions. The responses from the principals and teachers were analyzed and coded based on the trends that emerged. Transcripts were reviewed, highlighted, and underlined in order to code the material.

\section{Participants}

The participants in this study were teachers from three small nontraditional high schools that are located in the northern section of North Carolina. Each of these high schools already began one-to-one computing initiatives in their school districts. The total population of teachers within the three high schools was 72. School A started its one-toone initiative in August 2014 and had a population of 47 teachers (Stem High School). This school also had $42.8 \%$ of its students identified economically disadvantaged and was one of the 17 schools located in this school district. Additionally, $42.8 \%$ of the students were also on free and reduced lunch. The ethnicity breakdown for School A was $50 \%$ African-American, $40 \%$ White, and 10\% Asian. School A had a B grade on its school report card for the 2016-2017 school year from North Carolina Public School Report Card.

School B started its one-to-one laptop initiative in August 2012 and had a population of 13 teachers (Early College). School B, which is one of 17 schools in this school district, had a grade A on its school report card for the 2016-2017 school year. 
The school was also located in a high poverty area of the state and had $100 \%$ of its students enrolled in the free and reduced lunch program. School B had 45\% AfricanAmerican, 40\% White, and 15\% Native American and Asian students.

School C, which was one of nine schools in this school district, started its one-toone laptop initiative from August 2010 and had a population of 12 teachers (New Technology High School). This school district, which was located in a high poverty area, also had all of its students enrolled in the free and reduced lunch program, though only $39.8 \%$ of the students were identified economically disadvantaged. The school had a grade B on its school report card for the 2016-2017 school year from North Carolina Public School Report Card. School C had 50\% African-American, 40\% White, and 10\% Native American and Asian students. The school demographic information is outlined in Table 1.

Table 1

School Demographics

\begin{tabular}{lllll}
\hline School & $\begin{array}{l}\text { Implementation of } \\
\text { One-to-one Initiative }\end{array}$ & $\begin{array}{l}\text { Teachers on } \\
\text { Staff }\end{array}$ & $\begin{array}{l}\text { Free/Reduced } \\
\text { Lunch }\end{array}$ & $\begin{array}{l}\text { Schools in } \\
\text { District }\end{array}$ \\
\hline School A & August 2014 & 43 & $42.8 \%$ & 17 \\
School B & August 2012 & 12 & $100 \%$ & 19 \\
School C & August 2010 & 12 & $39.8 \%$ & 9 \\
\hline
\end{tabular}

\section{Research Questions}

The following research questions guided this study:

1. What are teacher perceptions of the quality of professional development after the implementation of a one-to-one computing initiative?

2. What are teacher perceptions of the time spent on professional development and its value for the teaching of their lessons? 
3. What are teacher perceptions of the value of the time allotted to teachers to have access to their devices prior to students having access to the similar device?

As it relates to Research Question 1, it is important to look at teacher perceptions of the quality of the professional development they were provided after the implementation of the one-to-one initiative.

In a study designed to examine the relationship between professional development in literature and self-reported change in teachers, Garet, Porter, Desimone, Birman, and Yoon (2001) found that the notion that external ideas alone will result in changes in the classroom and school is deeply flawed as a theory of action; therefore, professional development must not be viewed by teachers as irrelevant or poorly conducted, but the sessions should meet the highest standard of adult learning. These activities are not useless, but they can never be powerful enough, specific enough, or sustained enough to alter the culture of the classroom and school (Fullan, 2007).

The initial set of survey questions asked teachers to state their perception of the value of the professional development they received after the implementation of the oneto-one computer initiative. The questions gathered demographic data including data on the number of years the teacher had taught, the length of time teachers had access to their computing device prior to students, and how long professional development was given to teachers after the implementation of the one-to-one computing initiative. Teachers, as they responded to questions 1-4 on the survey (see Appendix A), were given an option of N/A which would show they gave no value for the questions. The sustainability of the one-to-one computer initiative is, to an extent, dependent on teacher perceptions of the one-to-one initiative. "A whole set of issues must be addressed simultaneously: structure, 
norms, deprivatization, focus on results, and improved instruction through continuous professional development" (Fullan, 2007, p. 36). Questions 1-5 on the survey asked teachers to state the district in which they teach, the years they have taught as a certified teacher, the length of time they had access to their computing device prior to students, and how long the school had undergone professional development to prepare them for implementation. The responses were placed into categories. These categories were then coded to ascertain trends. These trends were then discussed as they arose as a result of the survey and interviews.

Questions 6, 7, 8, 9 and 10 on the survey (see Appendix A) that focused on Research Question 2 asked teachers to state their perceptions of the time spent on professional development and if technology was valuable in helping with the planning and teaching of lessons. Based on teacher responses which ranged from never to once or twice yearly, once or twice a semester, once or twice a month, once or twice a week, or daily, this allowed the researcher to be able to determine the frequency of the use of technology in the classroom. Question 6 asked participants how the time spent on professional development aided them to deliver their instruction. Question 7 examined how often teachers used technology to deliver instruction in their class. Question 8 examined how often they used technology to assess student learning. Question 9 examined how often teachers used digital resources to supplement existing textbooks. Question 10 investigated how often teachers create and download presentations that can be utilized by the students outside of his or her classroom. The responses were then categorized, coded, and discussed based on the trends. This study aimed to discover the impact of the quality of professional development on the sustainability of a one-to-one computing initiative. As a result, it would be imperative that the researcher ascertained if 
the teachers perceived any value of the professional development they were given. The researcher, based on questions $6,7,8,9$, and 10, was able to see if there was any impact of the professional development on the lessons teachers plan for their students.

Questions 11, 12, 13, 14, 15, 16, and 17 (Appendix A) on the survey focused on Research Question 3 which is the relationship between professional development prior to implementation of the computing initiative and the actual change in teacher instructional practice after implementation of the computing initiative.

As Research Question 3 states, the researcher examined how teachers used technology. The aim was to ascertain if this time with the device impacted how the technology was used in the classroom. The questions asked participants how often they differentiated or personalized instruction for their students, how often they created learning activities to challenge students to think critically, how often they created a web page and platforms for instructions, and how often students completed classroom learning assignments and collaborated on assignments. Research Question 3 looked at the relationship between professional development prior to implementation of the computing initiative and the actual change in teacher instructional practice after implementation of the computing initiative. The researcher's analysis is based on the responses of the participants to the survey questions and the interviews.

Survey response questions that lent themselves to how frequently a strategy and/or item were used included six potential choices that ranged from never to daily. In particular, that would be questions 6-17 on the survey (see Appendix A).

\section{Analytical Methods}

This study focused on the findings from the survey the teachers completed. The teacher survey data and interviews were discussed so trends that arose were outlined. 
The aim of this study was to factually outline teacher perceptions of the quality of professional development after implementation, professional development's value to teachers, and the time allotted to teachers to have access to their laptop devices prior to students getting theirs; therefore, the study was qualitative in nature and examined teacher perceptions as stated in the research questions.

\section{Summary}

The purpose of this qualitative study was to determine the impact professional development had on the sustainability of a one-to-one computing initiative at the high school level. The study considered the impact of time spent to prepare teachers for the one-to-one laptop initiative, the time allotted to teachers with their laptops prior to student implementation, and how teachers valued the professional development they were afforded prior to roll out. The focus was on the types of professional development teachers were exposed to during their implementation and subsequent sustainment of the one-to-one laptop initiative.

In Chapter 4, teacher perceptions of quality professional development and its impact on the sustainability of one-to-one computing initiatives are discussed. Additionally, teacher perceptions of the use of technology during and after implementation are reviewed based on the data generated by the survey and interviews. The frequency of the use of technology and its correlation to the professional development activities which includes the amount of time teachers had to access their own laptops prior to implementation with students are also discussed. The length of the professional development teachers experienced in preparation for the one-to-one initiative implementation is also analyzed. It is also considered if teachers perceived the length of professional development teachers were given aided in preparing them for the 
one-to-one laptop implementation and subsequent sustainability. 


\section{Chapter 4: Results}

\section{Introduction}

“Today's students, known as digital natives, net-generation, the Google generation or the millennial are radically different from those of the past. Born into an era of instant connectivity and networking, they explore the world in an entirely new way" (Sutherland, 2016, p. 1). Students today interact differently, and they want instant feedback; for they are a "generation of students that grew up with technologies. The internet, cell phones, and Facebook, that allows them to connect with the world instantly" (Sutherland, 2016, p. 1). While learners in the past "valued face-to-face meetings, today's students prefer to connect via email and text messages" (Sutherland, 2016, p. 1). Technology has allowed us to "get the same information and value from a digital meeting that the previous generation got from an office meeting" (Sutherland, 2016, p. 1).

Effective integration of one-to-one computing initiatives within the classroom have to be supported by quality professional development and training (USDOE, 2010). The responses gathered in this research have been used to identify the value teachers have placed on professional development experiences as their school systems attempt to sustain a one-to-one computing initiative. This research also seeks to look at the impact professional development has on the sustainability of a one-to-one computing initiative at the high school level. The study also considers the impact of time spent to prepare teachers for the one-to-one laptop initiative, the time allotted to teachers with their laptops prior to student implementation, and how teachers value the professional development they were afforded prior to implementation. The focus is on the types of professional development teachers were exposed to during the implementation of the one-to-one computing initiative and to ascertain if professional development can aid in 
sustaining a one-to-one computing initiative.

Participants in the survey were asked to state the district in which they work. They were also asked to state how many years they have taught as a certified teacher and to rate their competency with technology. The survey then asked respondents to indicate the length of time they had access to their computing device prior to students. Question 6 on the survey asked teachers to rate various professional development they were exposed to at different times as well. Questions 5 and 6 spoke about professional development that was geared towards the teacher's individual preparation for the one-to-one computing initiative. Questions 7-11 highlighted how professional development teachers were exposed to assisted them to use technology in the planning of instruction, delivery of instruction, assessment of student learning, supplement of classroom resources, and lesson presentation. Questions 12-17 highlighted how teachers, based on their exposure to professional development, used instruction to assess learning and to have students use their devices for their learning. Interview question 3 asked participants to state what protocols their schools had in place for the one-to-one computing initiative. All schools had a contract that students and parents had to sign prior to students getting their computing device. All schools also required students to pay a $\$ 20$ fee in order to get the device to take home. Though the devices are insured, all schools required parents to pay to replace any missing and/or damaged devices.

\section{Participants}

Figure 2 shows the percentage of teachers who completed the survey. School A had 21 of a possible 47 teachers completing the survey which was $45 \%$. School B had 12 of a possible 13 teachers at the school completing the survey which was $92 \%$. School C had five of a possible 12 teachers on staff completing the survey which was $42 \%$. The 
total number of teachers who completed the survey was 38 of a possible 72 . This means that $53 \%$ of the teachers who were sent the invitation completed the survey. School B had 13 possible teachers who could have taken the survey, and only one did not complete the survey; however, School A had 47 participants who could have taken the survey, yet only 21 completed the survey. This showed that less than half the teachers on staff completed the survey. School $\mathrm{C}$ also had less than half of the teachers on staff completing the survey.

\section{Teachers Surveyed $=38 / 72$}

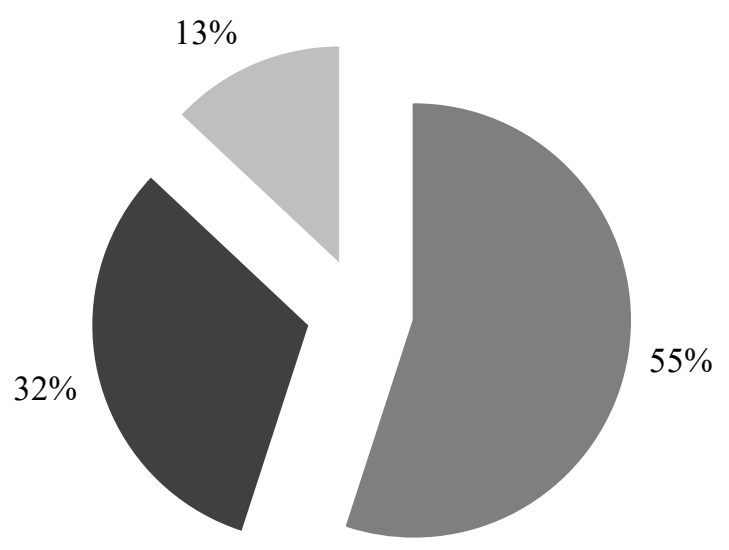

- School A

- School B

School C

Figure 2. Teachers Surveyed.

\section{Research Questions}

The following research questions guided this study:

1. What are teacher perceptions of the quality of professional development after the implementation of a one-to-one computing initiative?

2. What are teacher perceptions of the time spent on professional development and its value for the teaching of their lessons? 
3. What are teacher perceptions of the value of the time allotted to teachers to have access to their devices prior to students having access to the similar device?

\section{Research Question Data}

\section{Research Question 1: What were teacher perceptions of the quality of}

\section{professional development after the implementation of a one-to-one computing}

initiative? The survey questions and interview questions that provided the data for guiding Research Question 1 are illustrated in Table 2.

Table 2

Survey Questions and Interview Questions for Research Question 1

\begin{tabular}{ll}
\hline Survey Questions for Research Question 1 & Interview Questions for Research Question \\
\hline $\begin{array}{l}\text { 2. How many years have you taught in your } \\
\text { career as a certified teacher? }\end{array}$ & $\begin{array}{l}\text { Teacher and Principal Interview Questions } \\
\text { numbers } 2 \text { and } 6 \text { were the same. }\end{array}$ \\
$\begin{array}{ll}\text { 3. Identify your competency level with } \\
\text { technology. }\end{array}$ & $\begin{array}{l}\text { 2. What are the benefits of using a one-to-one } \\
\text { computing at your school? }\end{array}$ \\
$\begin{array}{ll}\text { 13. How often did you create a learning } \\
\text { activity designed to challenge students to } \\
\text { think in a critical manner }\end{array}$ & $\begin{array}{l}\text { 6. What type of professional development } \\
\text { would be more beneficial to you as your } \\
\text { school sustains the one-to-one computing } \\
\text { initiative? }\end{array}$
\end{tabular}

14. How often did you use technology to create your own web page, or use a content Teacher and Principal Interview Questions for management platform where students can access learning materials and/or turn in assignments in a digital manner?

16. How often did you ask students to collaborate on assignments?

17. How often did you ask students to post their work to communicate with a global audience?

In order to look at respondent perceptions of the quality of professional development after the implementation of a one-to-one computing initiative, let us look at 
what was indicated for question 2 on the survey. Figure 3 illustrates responses to survey question 2 which asked teachers to indicate how many years they had been a certified teacher. The results showed that $10.53 \%$ of the participants surveyed were certified for less than a year. Another $10.53 \%$ of the teachers had $1-2$ years of being a certified teacher. Also, $15.79 \%$ of the surveyed participants had 3-5 years of being a certified teacher. This amount grew to $21.05 \%$ for those who were certified for $6-10$ years. The highest amount of the participants was the $11-15$ year group, which had $42.11 \%$ of the participants being certified teachers for that length of time.

Before 2013, in North Carolina, teachers could complete a 4-year probationary period and then be able to get tenure. If that was still the case, $63.16 \%$ of the participants surveyed would have been career teachers. According to the North Carolina Teacher Evaluation tool, one responsibility of teachers is that they know and understand their standards. As a result, teachers should be able to take advantage of professional development that would assist them to use technology to enhance their content.

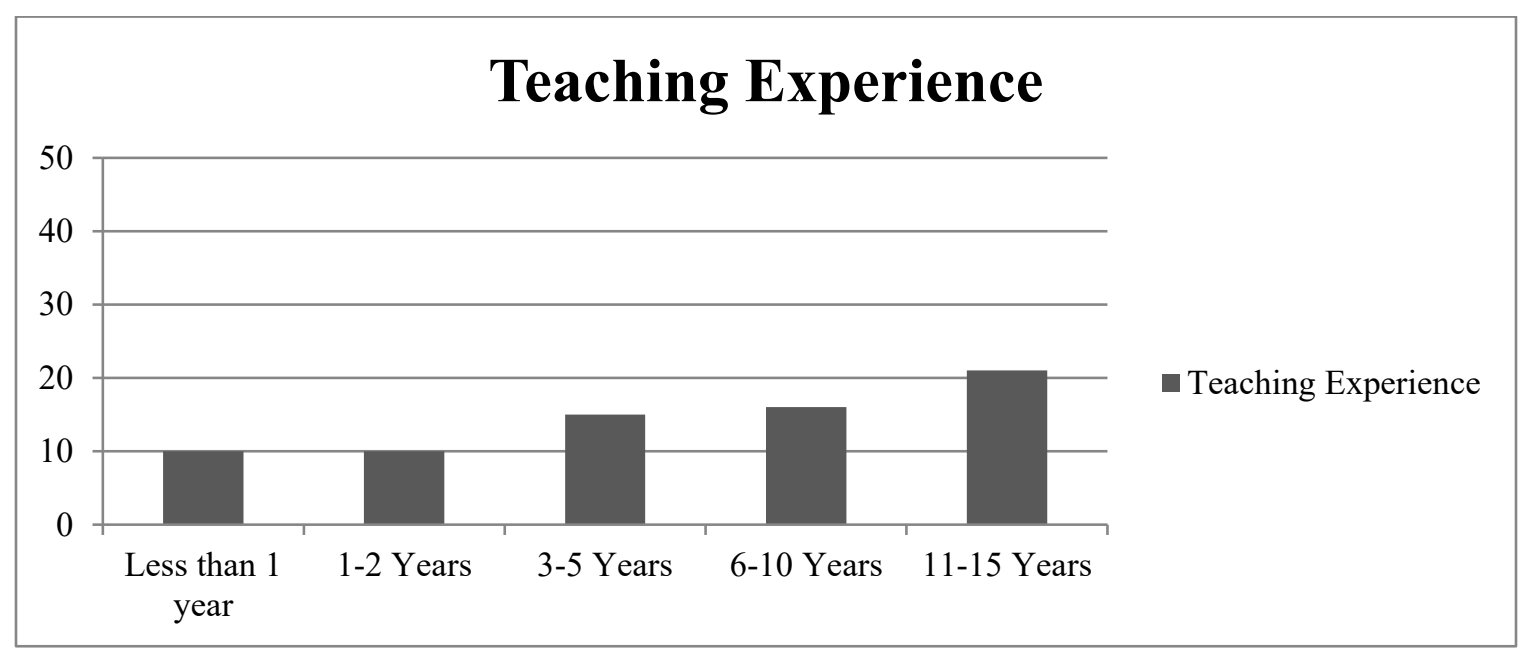

Figure 3. Teaching Experiences of the Teachers at Schools A, B, and C.

There are many qualities of an effective teacher. According to Tucker and 
Stronge (2018), studies have shown that effective teachers have a number of qualities which include "having taught for at least three years, and are able to present information to students in a meaningful way" (p. 1). The data indicate that $63.16 \%$ of the respondents to survey question 2 would fulfill the criteria of being an effective teacher based on the qualities outlined by Tucker and Stronge; thus, the participants in this study should be able to give credible information about their perceptions of quality professional development.

Interview question 2 for both teachers and principals asked interviewees to outline the benefits of using a one-to-one computing initiative in a school. The participants indicated that technology allowed teachers and students to be able to research and have information readily available in the classroom. A teacher at School C, who responded on the survey and labeled themselves as an advanced technology educator, stated, "education levels the playing field for the students who are located in rural areas." The teacher went on to say that "students in rural areas may never leave that community, but the use of technology will enable students to explore other parts of the world."

Continued review of the research related to Research Question 1 and analysis of the data to decipher teacher perceptions of the quality of professional development after the implementation of a one-to-one computing initiative are further detailed in survey question 3 which is illustrated in Figure 4. Figure 4 illustrates the perceived competency level participants in the survey identified they had with technology. Only $2.63 \%$ who participated in the survey said they were a novice when it comes to technology. Figure 4 also shows that $50 \%$ of the participants in the survey said they were at the intermediate stage when it comes to their competency with technology. Also, $44.74 \%$ of the teachers said they would consider themselves to be advanced when it comes to the use of 
technology. Similar to the results for novice, only $2.63 \%$ of the teachers said their competency level could be considered as an expert. As we consider the data, respondents should be able to "effectively integrate technologies that are compatible with the standard course of study, the State assessment program, and related student data management" (North Carolina State Board of Education, 2017, p. 1). We must also consider that one of the expectations of the TPACK model and the North Carolina digital learning competencies is for teachers to be able to integrate technology into their lesson, so the teaching and learning environment can be enhanced.

\section{Competency Level With Technology}

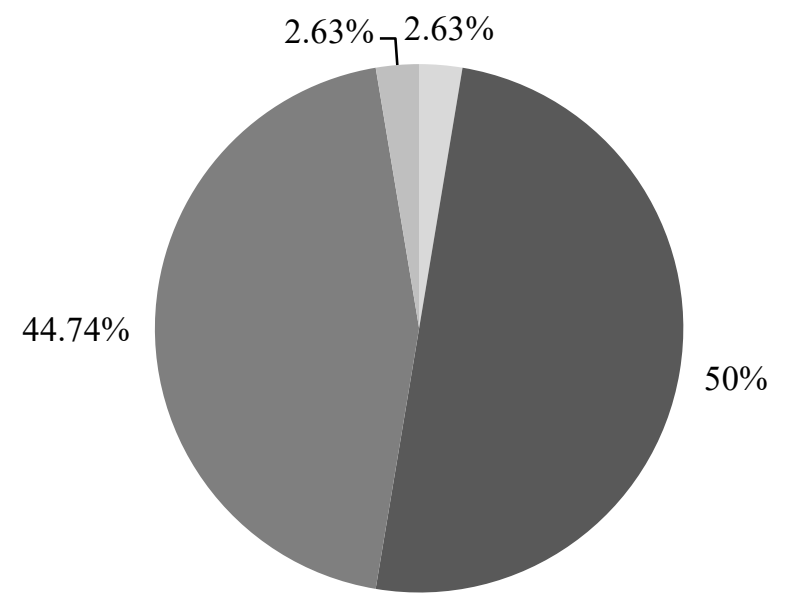

Novice

- Intermediate

- Adavance

$\square$ Expert

Figure 4. Competency Level with Technology.

Figure 4 shows $97.37 \%$ of the respondents stated they were either an intermediate, advanced, or expert user of technology, and it indicates self-selected teacher competency levels. Teachers illustrated positive self-efficacy about their competency with technology. The response that is evident for interview question 6 , which asked what professional development would be more beneficial to them as the school sustains one-to- 
one, highlighted that respondents felt professional development that is geared towards meeting their pedagogical need would be what they would like to see more of as their school district attempts to sustain the one to one computing initiative. Interestingly, principals stated in their interviews that they also wanted professional development that focused on teachers and was differentiated based on the subjects teachers taught. Considering the data, even though the respondents stated that most of them felt they were intermediate, advanced, or an expert when it comes to technology, professional development that is content specific would enable them to teach more effectively in their one-to-one computing initiative environment.

Interview question 7 asked interviewees to identify in what ways their one-to-one computing initiative influenced how time is spent during professional development days. Most interviewees stated that time was mostly spent with professional development that focuses on using technology for accountability. As we look at responses to interview question 7, participants stated that more time should be spent on allotted professional development days on exposing teachers to content specific technology use that would aid in their instruction. School B respondents had also stated during their interview that the Friday Institute has been training selected teachers from varied schools in their district, so they can return to their individual schools and train other teachers; however, this training is not based on teacher content. The Friday Institute is located at North Carolina State University's campus, and they focus on helping schools to become future-oriented organizations. The Friday Institute works with policy makers, private institutions, and educators in order to assist teachers to be better able to empower their students. The institute provides training with the use of technology for instruction and is designed to respond to the needs of the district that contracts their services. 
All respondents during the interviews stated that any type of professional development that is offered after the implementation of a one-to-one computing initiative should be done based on teacher content. The data indicate that respondents feel as if the professional development that they are being given right now is good. A teacher who was interviewed indicated that "the professional development prior to implementation was quite substantial and useful." On the other hand, the teacher went on to state that if they could have professional development that was driven by their specific content that would cater more to their needs.

Survey question 13 asked participants to indicate how often a learning environment was designed to challenge students to think in a critical manner. Data included in Figure 5 shows that prior to the implementation of the one-to-one computing initiative, $2.70 \%$ of the participants indicated never creating a learning activity designed to challenge students to think in a critical manner; none indicated once or twice a year; $8.11 \%$ indicated once or twice a semester; $13.51 \%$ indicated once or twice a month; $45.95 \%$ indicated once or twice weekly; and 29.73 indicated daily. After the one-to-one computing initiative was started, none of the participants indicated they had never created a learning activity designed to challenge students to think in a critical manner; none indicated once or twice a year; $2.63 \%$ indicated once or twice a semester; $7.89 \%$ indicated once or twice a month; $50 \%$ indicated once or twice a week; and $39.47 \%$ indicated daily. While the overall percentage increased to weekly or daily use after the implementation, the daily use of a learning activity designed to challenge students increased by nearly $10 \%$.

The data indicate that implementation of a one-to-one computing initiative did not lead to a substantial change in the frequency of learning activities being designed to 
challenge students to think critically. Figure 5 shows a growth in the once or twice a week and the daily use of technology to create a learning activity that was designed to challenge students to think in a critical manner, but it was minute. This is in contrast to the expectation of North Carolina State Board of Education (2017), which requires that educators "effectively integrate technologies that are compatible with the standard course of study, the State assessment program, and related student data management" (p. 1). An integral part of the effective integration of technology is to ensure that students are expected to think in a critical manner. A teacher who was interviewed stated that there is a need for professional development that will focus on not only showing teachers how to use technology effectively, but will also "aid in teachers ensuring that their activities are ensuring that students are thinking critically." As we consider the data and the increased focus on technology integration in the classroom, teachers must be exposed to professional development that models the integration of technology based on their content. Additionally, if teachers are exposed to content specific professional development, their ability to incorporate technology into their lessons based on the North Carolina digital learning competencies may be increased. Content specific professional development may also increase teacher ability to effectively use the TPACK model as is expected by legislators and their school district. 


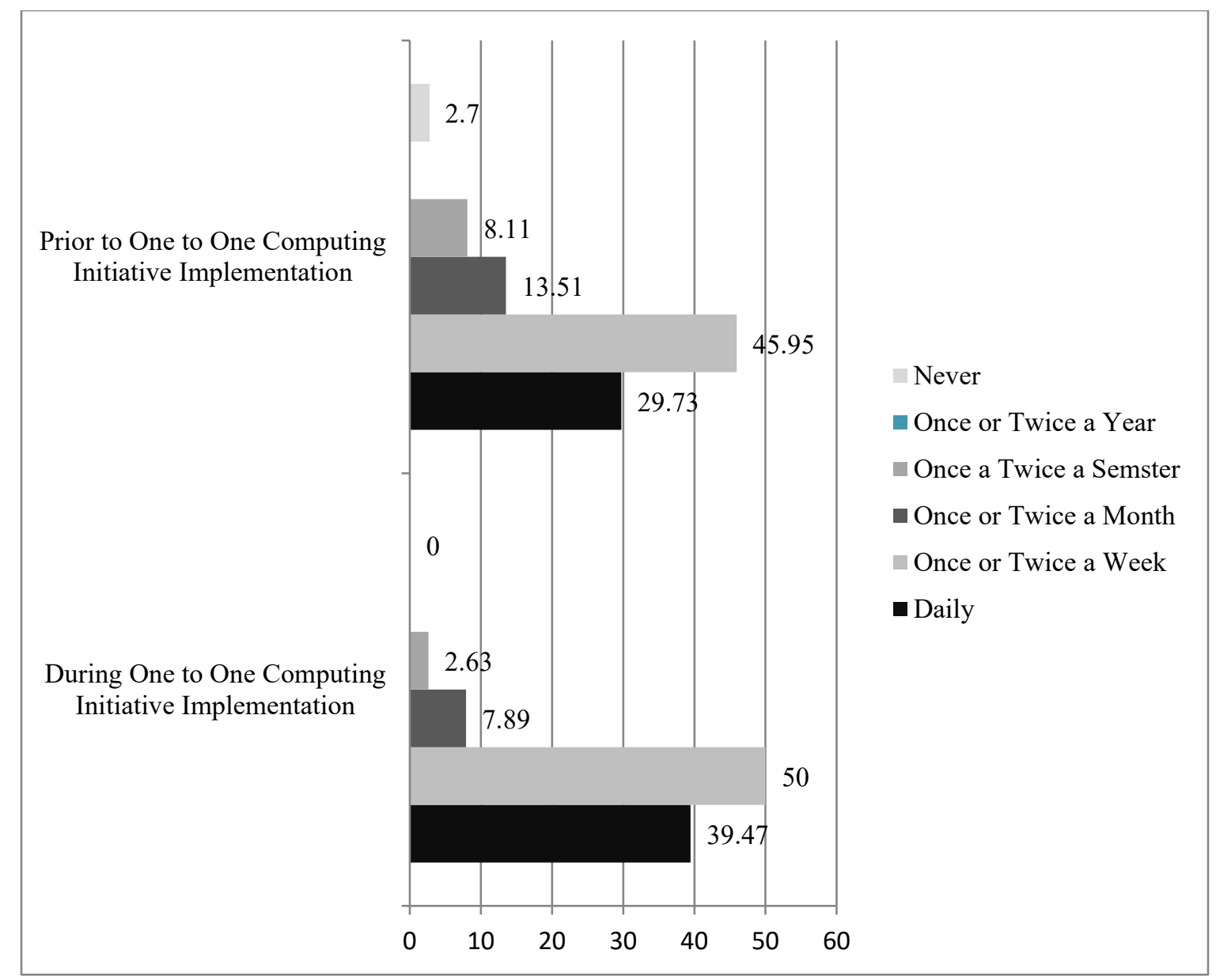

Figure 5. Learning Activity that was Designed to Challenge Students to Think in a Critical Manner.

The data in Figure 5 indicate that if teachers are exposed to professional development that caters to teachers based on their content, the result could be an increase in the critical thinking activities students are given in class. The data included in Figure 5 indicated that a majority of the respondents are doing the same as they were doing before implementation of a one-to-one computing initiative during the implementation. If professional development was being done with a focus on the use of technology to improve instruction based on respondent pedagogy, there may have been a greater increase in the once or twice a week and the daily creation of a learning activity that 
challenged students to think critically.

Teacher participants were asked for survey question 14 to indicate how often technology was used to create a class web page or use a content management platform where students can access learning materials and/or turn in assignments in a digital manner. As Figure 6 illustrates, prior to one-to-one implementation, teacher participants indicated that $29.73 \%$ never used a class web page or used a content management platform where students can access learning materials and/or turn in assignments in a digital format; $2.70 \%$ indicated once or twice a year; $10.81 \%$ indicated once or twice a semester; $10.81 \%$ indicated once or twice a month; $21.62 \%$ once or twice a week; and $24.32 \%$ indicated daily. During the implementation of the one-to-one computing initiative, the responses in Figure 6 indicate teachers have increased their use of technology to create a web page or content platform that students can use to access class materials and/or submit their assignments. All the schools that participated in this study have their teachers use Rapid Identity and its various applications that are offered by the state. Some of the applications available through Rapid Identity are Canvas, True North Logic teacher evaluation tool, and Powerschool.

A teacher indicated during the interview that teachers needed more professional development that focused on the deliberate use of "various content management platforms." The teacher went on to state that "technology is constantly changing, and even though Rapid Identity's Canvas is available, there are other resources that are as well, such as Google Classroom." The teacher was of the belief that school districts should state specifically what they want teachers to use as a content management platform for their instruction. Canvas is one application that was mentioned, which is available as an option in the state based Rapid Identity. On the other hand, the teacher 
said that "additional training was needed to clarify Rapid Identity and its applications use as a content management platform." It could be a lack of understanding of the available content management platforms that led to the data illustrated in Figure 6.

There was an increase in the use of content management platforms; however, as Figure 6 illustrates, even though the number of respondents who indicated never using a web page and/or content management platforms did decrease from $29.73 \%$ before implementation to $16.22 \%$ during implementation. That amount could be even lower if professional development catered to teachers based on not only subject area, but also in terms of the needs of the respondents. One must bear in mind as well, that only $53 \%$ of those who were invited to complete the survey participated. The number of teachers who do not use a web page or online content management platform could be higher.

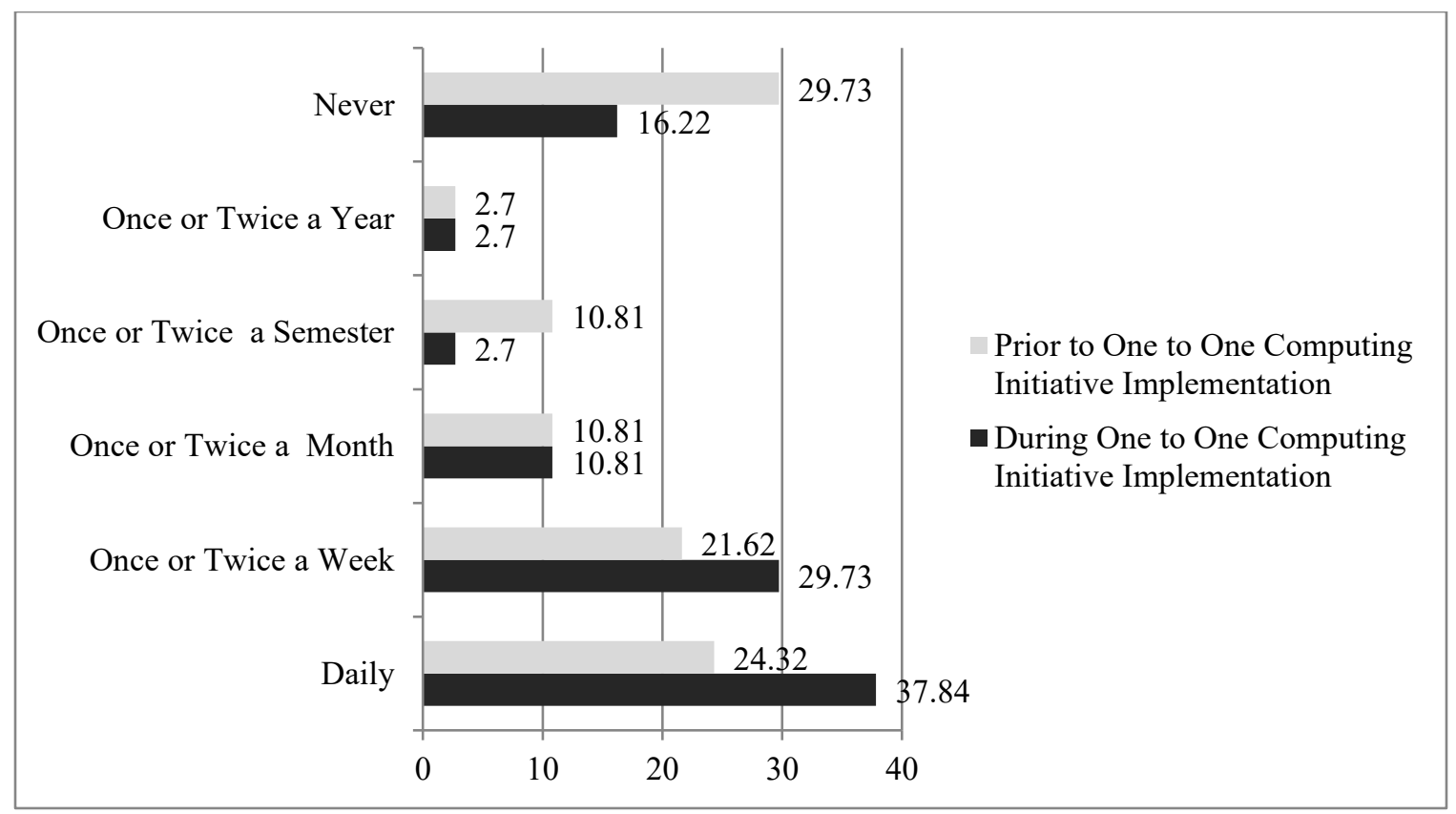

Figure 6. Technology Used to Create a Web Page or Content Management Platform Where Students Can Access Learning Materials and Submit Assignments.

Survey question 16 asked teacher participants to indicate how often students were 
asked to collaborate on assignments. Data in Figure 7 illustrates that prior to the one-toone computing initiative implementation, $8.11 \%$ of teacher participants indicated that students never collaborated on assignments; $0 \%$ indicated once or twice a year; $10.81 \%$ indicated once or twice a semester; $29.73 \%$ indicated once or twice a month; $35.14 \%$ indicated once or twice a week; and $16.22 \%$ indicated daily. After one-to-one computing implementation, teacher participants indicated that $5.41 \%$ of their students never collaborated on assignments; $0 \%$ indicated once or twice a year; $5.41 \%$ indicated once or twice a semester; $10.81 \%$ indicated once or twice a month; $54.05 \%$ indicated once or twice a week; and $24.32 \%$ indicated daily student collaboration.

Based on the data illustrated in Figure 7, there was an increase from half of the students collaborating on assignments prior to implementation to over three fourths of the students after implementation of the one-to-one computing initiative. Students collaborating weekly increased by $18.91 \%$, and daily increased by almost $9 \%$. The data show that there was a significant increase in students collaborating weekly and daily on assignments. Interview question 8 , which asked respondents if there was anything they would like to add, had interviewees indicating that they saw the benefit for students collaborating on assignments. Interviewees went on to state that students are from the rural area, and they will benefit from working not only with each other but also students from other schools. Interviewees also added that many of their students rarely leave their homes; as a result, teachers wanted to ensure that they use technology to connect students with other students via applications such as Skype. 


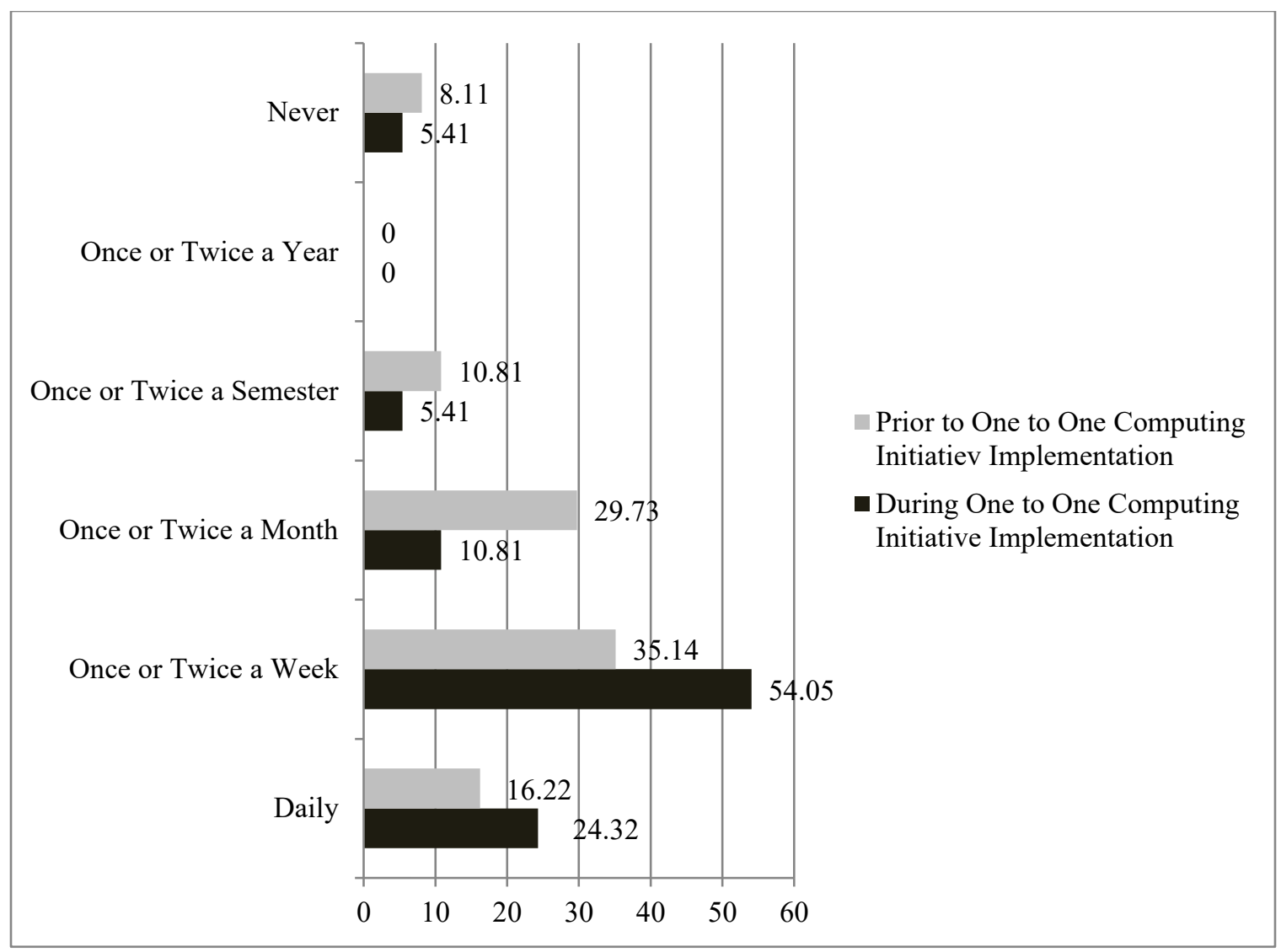

Figure 7. Frequency with which Students Collaborated on Assignments.

Survey question 17 asked teacher participants to indicate how often students would post their work to or communicate with a global audience outside of the school community. Figure 8 indicates that prior to the one-to-one computing initiative implementation, $24.32 \%$ of the teacher participants indicated that students were never asked to post assignments to or communicate with a global audience other than the school community; $8.11 \%$ indicated once or twice a year; $27.3 \%$ indicated once or twice a semester; $10.81 \%$ indicated once or twice a month; $16.22 \%$ indicated once or twice a week; and $13.51 \%$ indicated daily. Based on the data presented in Figure 8, there has not been much of a change before or during the one-to-one computing initiative implementation when it comes to students being asked to post assignments to or 
communicate online. The most noticeable change was that the never option prior to implementation was $37.84 \%$ which declined to $24.3 \%$ during implementation.

While Figure 7 data indicate there was an increase during implementation of respondents having students collaborate on assignments; in contrast, the data do not show a significant increase in respondents asking students to communicate with a global audience. The trend, as we look at the data for all questions, is that if teachers used to do an activity prior to implementation, they may see an increase of that activity during implementation. An example of this is that prior to implementation, if students were asked to collaborate on assignments, during implementation respondents continued to do this; however, if it was something respondents were not doing prior to implementation, there is not much of an increase during implementation.

Respondents did not report a high occurrence of students being asked to post their work to or communicate with a global audience prior to implementation. During implementation, this trend continued. Interviewees indicated that content specific professional development would assist them to effectively incorporate technology into their classroom. The data suggest that content specific professional development may also assist respondents to be able to increase their requiring of students to post their work to or communicate with a global audience. 


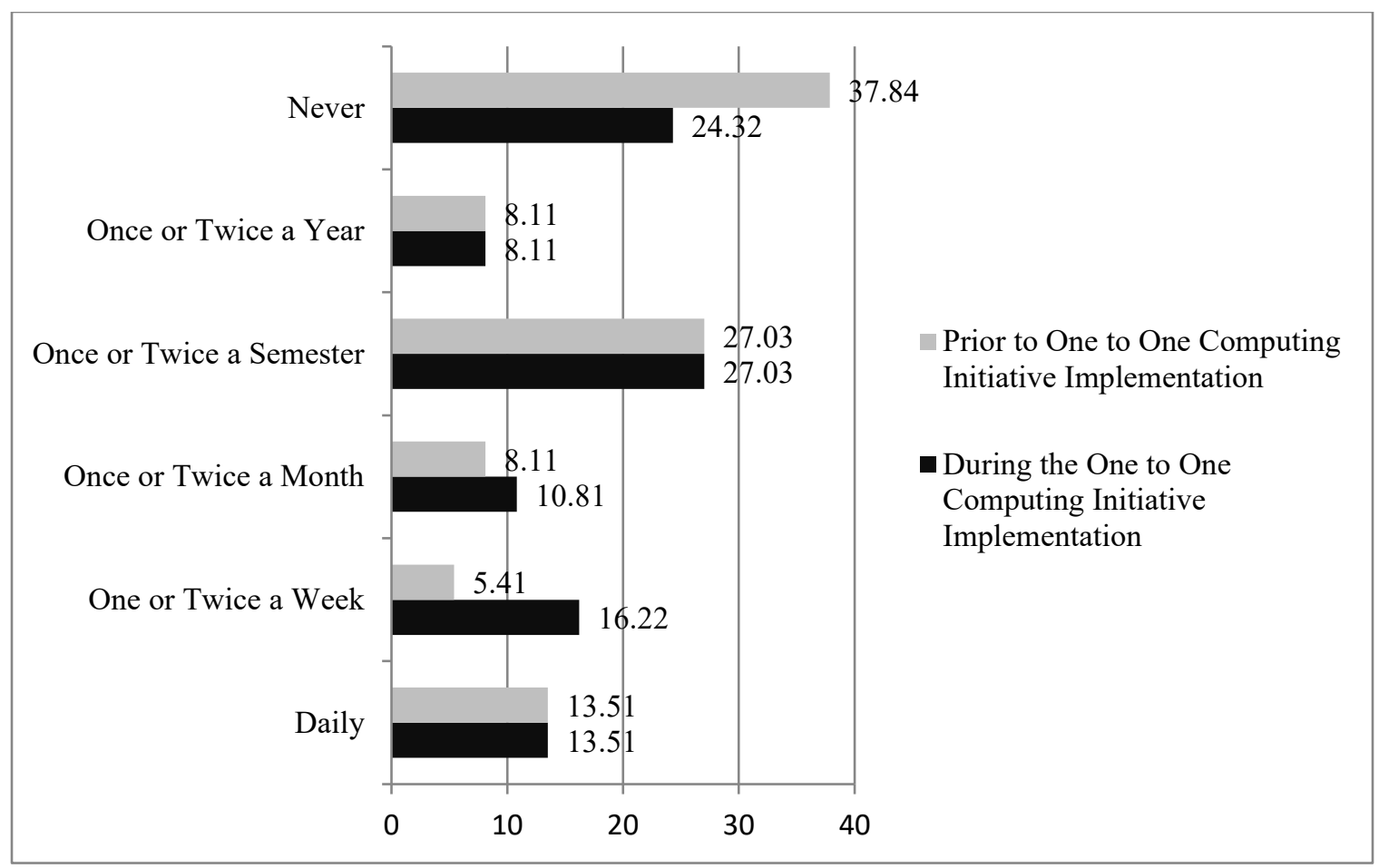

Figure 8. Frequency that Students were asked to Post Assignments to or Communicate with a Global Audience.

Figure 8 illustrates that prior to the one-to-one computing initiative implementation, $37.84 \%$ of the respondents never asked students to post their work to or communicate with a global audience. Figure 6 also illustrates that during implementation, $16.22 \%$ of respondents did not use a web page or use an online content management platform where students can access materials for the class or turn in assignments. Figure 7 shows $5.41 \%$ of the respondents indicated they have never asked students to collaborate on assignments. Based on the trends of the responses, teachers may need professional development that will cater to assisting them to be able to use content management platforms, and be taught various ways students can collaborate on assignments.

It is pertinent to note that, as was stated in Chapter 1 of this study, the model that 
is used in North Carolina is the TPACK model; thus, teachers are expected in North Carolina to ensure that as they teach their pedagogy, they use technology seamlessly. Therefore, the ultimate aim is to "effectively integrate technologies that are compatible with the standard course of study, the State assessment program, and related student data management" (North Carolina State Board of Education, 2017, p. 1). As a result, to have teachers say they have never used technology to create their own web page or use an online content management platform where students can access learning materials and/or turn in assignments, as was the case in Figure 6 for Question 14 for the survey questions, goes against what is expected of them as professionals. North Carolina State Board of Education (2017) stated that all teachers are expected to create a web page or use an online content management platform as they manage student data and teach students.

Students should be collaborating irrespective of a one-to-one computing initiative. Teachers are expected to differentiate instruction as they meet the needs of all students in their classroom. Teachers may be unaware of how to have their students post their work and communicate with a global audience which may lead to the data in Figure 8. This is something teachers may have been thinking when they stated in the interview for question 6 that course specific professional development would be something that is needed as their district moves forward with the one-to-one computing initiative. In regard to Research Question 1, teachers believed that quality professional development after the implementation of a one-to-one computing initiative should include content specific professional development. It would be in the best interest of a school district to ensure that professional development that focuses on the use of technology in instruction by course is one that is continuous. 


\section{Research Question 2: What were teacher perceptions of the time spent on}

professional development and its value for the teaching of their lessons? The survey

questions and interview questions that provided the data for guiding Research Question 2

are illustrated in Table 3.

Table 3

Survey Questions and Interview Questions for Research Question 2

\begin{tabular}{ll}
\hline Survey Questions for Research Question 2 & $\begin{array}{l}\text { Interview Questions for } \\
\text { Research Question 2 }\end{array}$ \\
\hline $\begin{array}{l}\text { 6. Rate professional developments- learning to use hardware, learning } \\
\text { to use software, learning to use content, learning to implement } \\
\text { technology within instruction - as to its respective value in your } \\
\text { individual preparation for the one-to-one computing initiative. }\end{array}$ & $\begin{array}{l}\text { Teacher and Principal } \\
\text { Interview Questions for } \\
\text { numbers 1 and 5 were similar. }\end{array}$ \\
$\begin{array}{ll}\text { 7. Based on the time spent on professional development, how often } \\
\text { did you use technology in your plan for instruction? }\end{array}$ & $\begin{array}{l}\text { 1. What is your perception of } \\
\text { technology in education? }\end{array}$ \\
$\begin{array}{l}\text { 8. Based on the time spent on professional development, how often } \\
\text { did you use technology to deliver instruction in your class? }\end{array}$ & $\begin{array}{l}\text { 5. Has there been professional } \\
\text { development that assists you } \\
\text { with your pedagogy in this } \\
\text { one-to-one environment? }\end{array}$
\end{tabular}

9. Based on the time spent on professional development, how often did you use technology to assess student learning?

10. Based on the time spent on professional development, how often did you use digital resources to supplement your existing textbook and/or curriculum?

11. Based on the time spent on professional development, how often did you use technology to create and/or download presentations that can be utilized by students outside of the classroom?

12. How often did you use technology to differentiate or personalize instruction to meet the unique needs of individual students in your classroom?

15. How often did you ask students to use digital technology to complete classroom learning assignments?

Research Question 2 guided the research so teacher perceptions of the time spent on professional development and its value for the teaching of their lesson could be ascertained. Survey respondents were asked for survey question 6 to rate the value of each specific type of professional development for its value in their own individual 
preparation for the one-to-one computing initiative. Those results are reported in Figures 9, 10, 11, and 12. Figures 9, 10, 11, and 12 also illustrate that teachers preferred professional development that focused on them learning to implement technology within their instruction. This response, though not having the highest percentage, was the only one that respondents noted as having a significant value to their preparation.

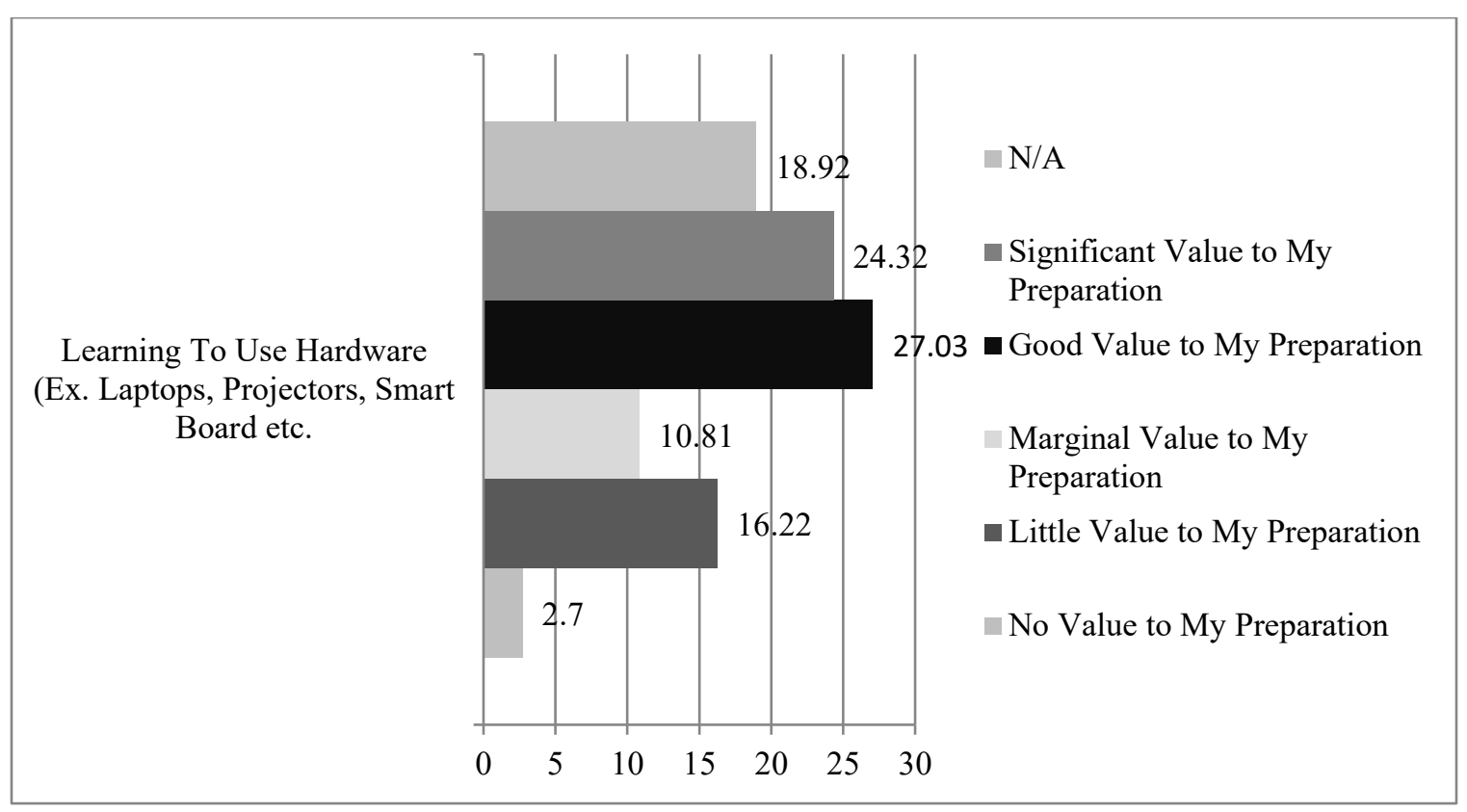

Figure 9. Learning to Use Hardware. 


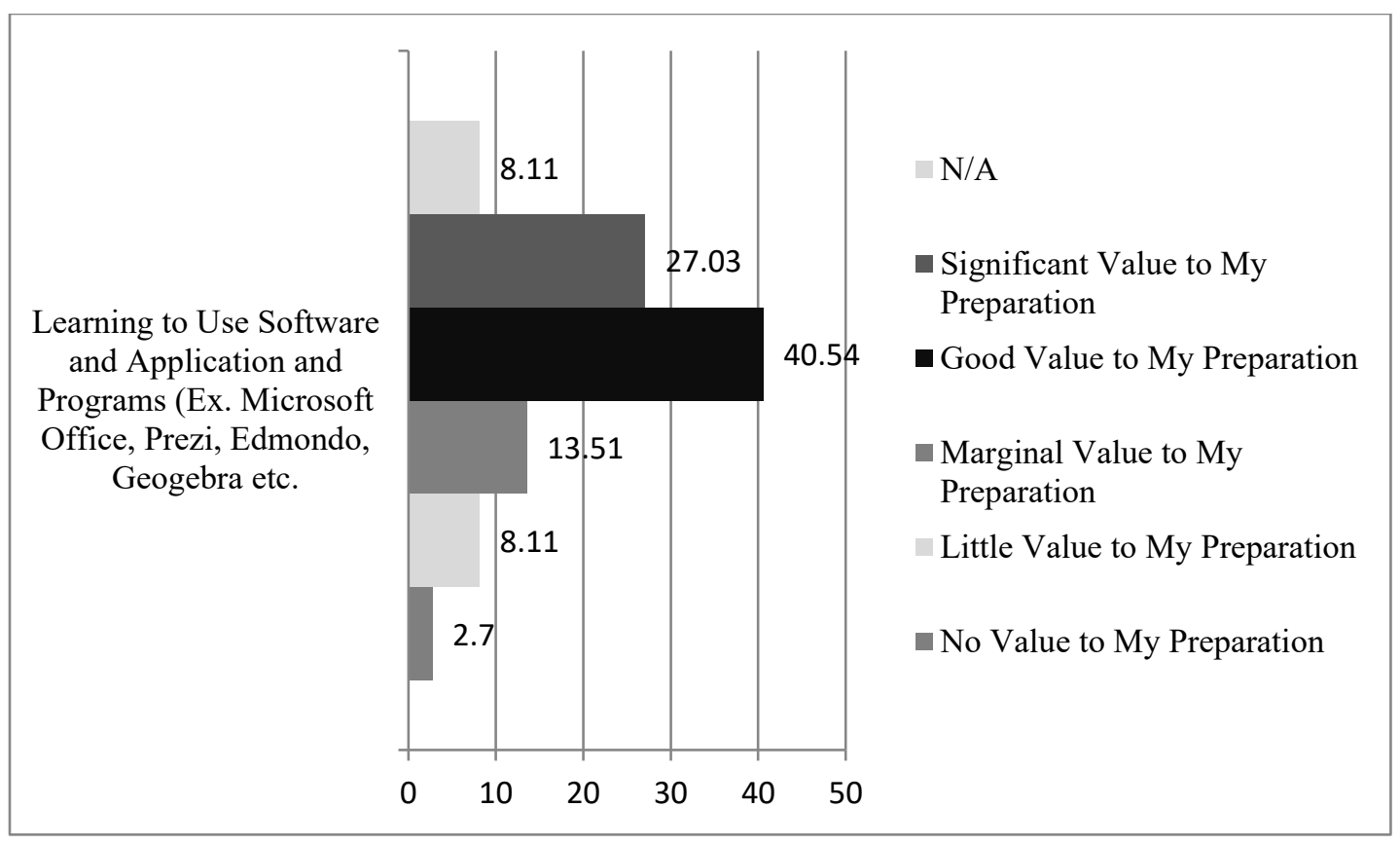

Figure 10. Learning to Use Software and Application Programs.

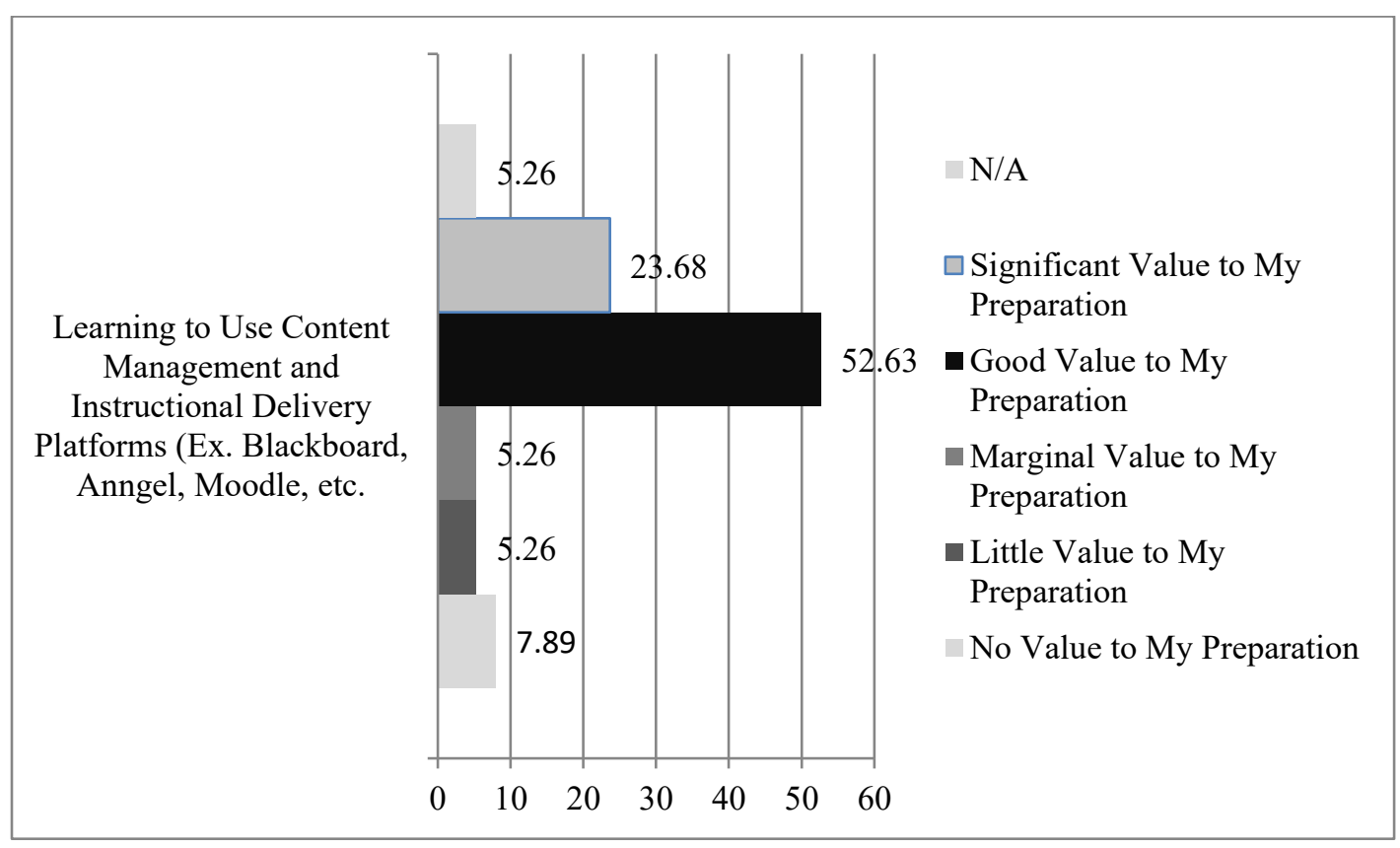

Figure 11. Learning to Use Content Management and Instructional Delivery Platforms. 


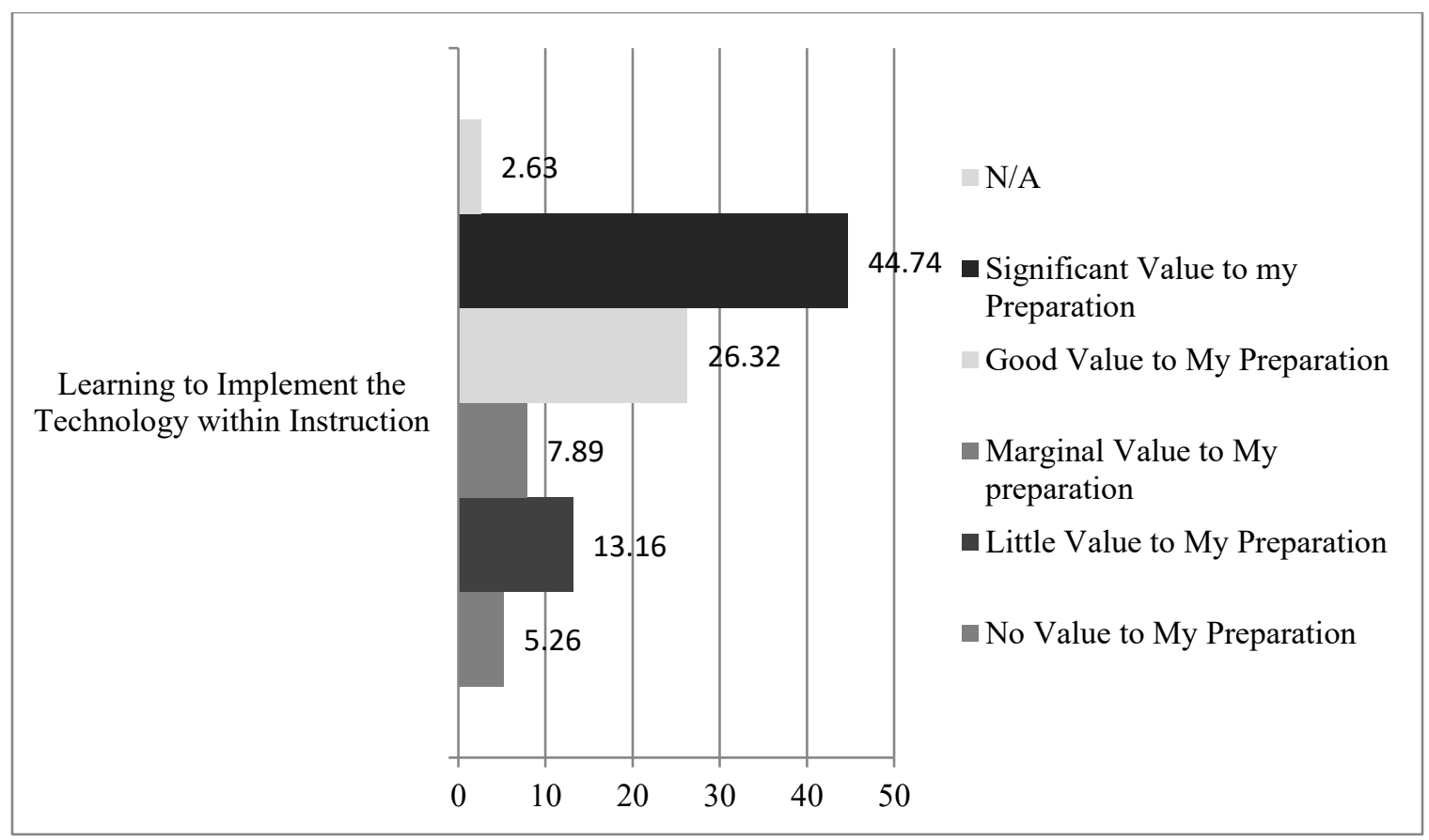

Figure 12. Learning to Implement the Technology within Instruction.

According to responses to survey question 14, during implementation of the oneto-one computing initiative, there were still $16.22 \%$ of the respondents who had never used online content platforms in their classrooms. With the schools having a one-to-one computing initiative being implemented, there would be a need to ensure that teachers have a web page or an online content management platform that allows students to access learning materials and/or turn in assignments. Even though respondents did not state that learning to use content management and instructional delivery platforms was significant to their value, the data suggest that there is additional need for professional development in this area. As stated earlier, when teachers were asked to indicate for survey question 14 if they create their own web page or use a content management platform that allows students to not only access learning materials but to be able to turn in assignments in a digital format, $16.22 \%$ of the respondents stated never. This amount was $29.73 \%$ prior to 
implementation. Though there was a decline in the percentage of respondents who did not use a content management platform, $16.22 \%$ of the respondents indicated they never use content management platforms. This means their students have no way of accessing or submitting classroom materials in a digital format. North Carolina State Board of Education (2017) stated that teachers must have an online student data management platform. Student access to information for their class can impact their class scores; therefore, it is imperative that respondents be exposed to professional development that stresses the importance of enabling students to have access to classroom materials so all teachers can have a technological content management platform they know how to effectively use.

This is where the consistent and continuous professional development for teachers based on their course will be critical. At the time of implementation, teachers may not have realized the need to ensure that they are aware of the use of online content management platforms for instruction in their classes. All participants of the interview stated in response to interview question 1, which asked for their perception of technology in education, that technology is a tool that should be used to enhance the teaching and learning environment. No interviewee gave an example of what they meant when they talked about using technology as a tool. One principal said that he did not want his teachers using technology to replace the paper and pencil way of note-taking. The principal would rather teachers be creative as they "think of new ways to engage students to think critically."

The data for survey question 6 indicated that not all respondents may be aware that an online platform can be used for a number of things such as assessment of students, location for students to post their assignments, and to be a medium to facilitate 
communication with a global audience. Continuous content specific professional development may assist in getting respondents to see the varied tools and resources technology can afford teachers in the classroom. Based on the responses to survey question 6 in relation to Research Question 2, it seems as if teacher perceptions of the time spent on professional development and its value for their teaching of their lessons are based on teacher perceptions as they look at the lessons they planned prior to a oneto-one computing initiative. Respondents may not have fully grasped the expectation of a one-to-one computing initiative even though the school district may be earnestly offering professional development. As school districts attempt to sustain a one-to-one computing initiative, a focus must be placed on a system that will allow the school district to continuously check to ascertain the needs of its teachers and ensure that the initiative continues.

Respondents were asked for survey question 7 to state how often they used technology in their plan for instruction. Figure 13 illustrates that prior to one-to-one implementation, $24.32 \%$ of the respondents indicated that they used technology once or twice a week as they planned for instruction. Prior to implementation, 51.35\% respondents indicated a daily use of technology in their planning for instruction. After the one-to-one implementation, the daily use of technology to plan for instruction increased by $17 \%$. This shows that professional development during one-to-one implementation assisted participants to be better able to use technology to plan for instruction. The data in Figure 13 indicate that the majority of the increase in technology use to plan for instruction occurred for daily use, while the percentage for never and once or twice a year remained the same for prior to and during implementation. The trend of teachers increasing the use of technology they had been using prior to implementation to 
during implementation continued. Respondents indicated that prior to implementation, $13.51 \%$ of them used technology to plan for instruction, and this declined to $2.63 \%$ after implementation; however, the daily use increased from $51.35 \%$ prior to implementation to $68.42 \%$ during implementation, which continued the trend of improved usage of technology prior to implementation to after implementation.

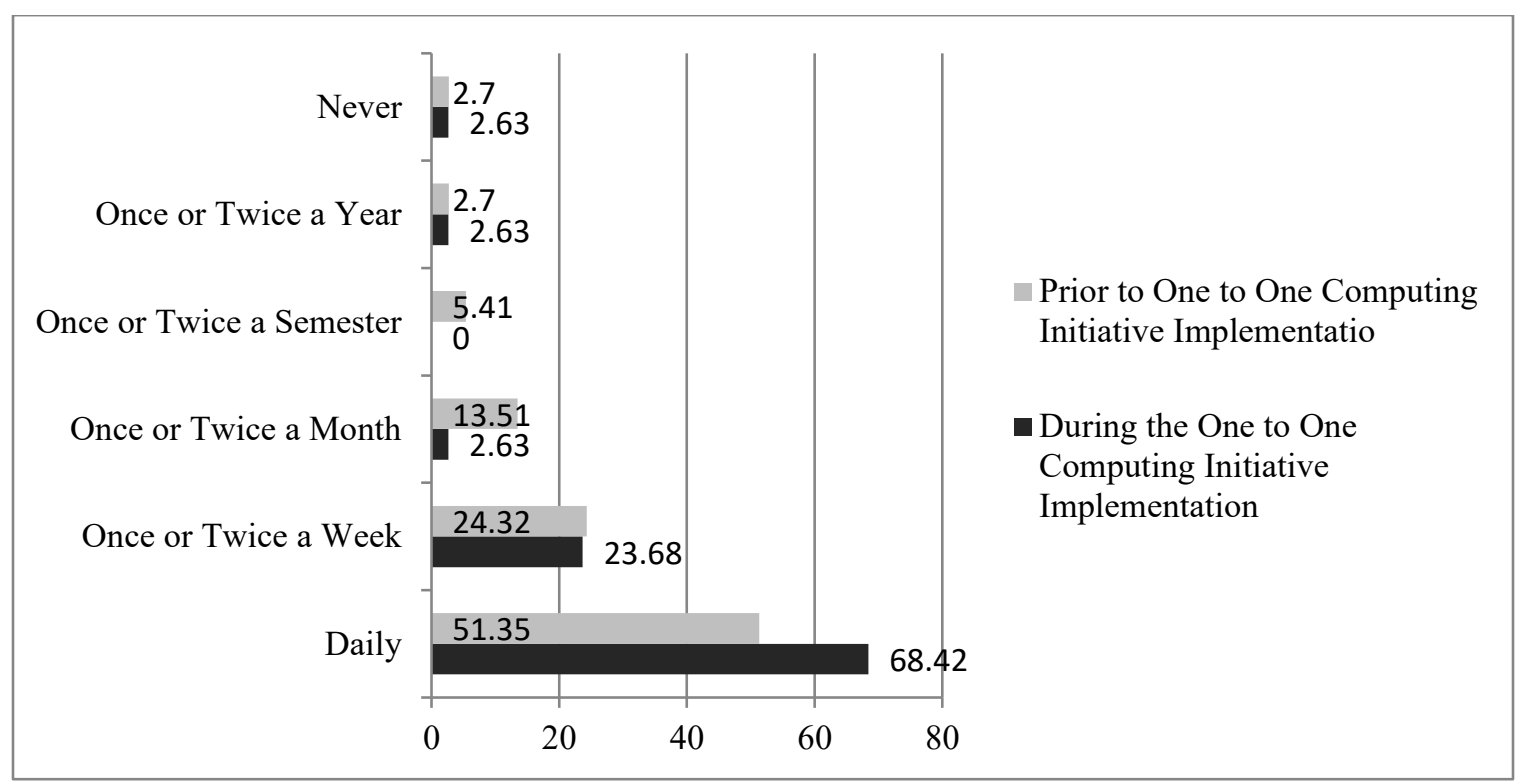

Figure 13. Frequency of Technology Use Before and After One-to-One Implementation to Plan for Instruction.

Question 5 on the interview asked the interviewees to state if they had any professional development that was specifically done to assist them with pedagogy. Interestingly, all teachers agreed with one interviewee who stated that the "majority of the professional development had been general." Teacher participants talked about professional development being centered on accountability and how to use the computing device in their classrooms in general. None made mention of professional development that was geared specifically to their pedagogy. Additionally, School B faculty talked about having instructional coaches who ensured that they incorporated the use of 
technology in professional learning communities that were held to address their pedagogy. They also talked about their school district utilizing the Friday Institute to train select teachers. After these selected teachers were trained by the Friday Institute approximately five times for the school year, they had to return to their school and train other teachers. Teacher participants in the interviews stated they found this quite helpful.

In the case of the principals, question 5 asked them to state how professional development was used to sustain the one-to-one computing initiative at their school. Principals responded that teachers are exposed to professional development in staff meetings, and teachers shared best practices with each other. As we consider the responses to interview question 5 and the data for survey question 7 , it is clear that teachers indicated they want to use technology to plan for instruction. As the data show, during implementation, $68.42 \%$ used technology daily to plan for instruction; however, data for interview question 5 for both teachers and principals show the common responses were that professional development is too general and needs to be done in a way that is content specific so teachers can maximize what is being offered. One teacher during the interview stated, "though I am happy for the training that I get with the Friday Institute, I would find it more beneficial if the training was based on the course that I teach." Another teacher in the interview stated, "if professional development was based on my subject, I would find it quite useful." The aim is to continue using technology in the classroom; but based on survey respondents and interviewees, they want to be exposed to professional development that is based on their content area.

Survey question 8 asked participants to indicate, based on the time spent on professional development, how often they used technology to deliver instruction in their class. Figure 14 illustrates that all respondents indicated they used technology to deliver 
instruction prior to implementation. In contrast, teacher participants stated that once their one-to-one computing initiative started, $0 \%$ never used technology to deliver instruction; $2.63 \%$ used technology once or twice a year; $2.63 \%$ stated once or twice a semester; $5.26 \%$ stated once or twice a month; $18.42 \%$ stated once or twice a week; and $71.05 \%$ stated daily. This is an increase from prior to one-to-one computing initiative from $56.76 \%$ daily to 71.05 daily. The daily use of technology to deliver instruction saw a growth, but the total was $71.05 \%$. The data illustrated the highest daily use technology for any survey question; however, the schools all have a one-to-one computing initiative, therefore the use of technology to deliver instruction, as is outlined by TPACK, on a daily basis should be higher. As was indicated by the those who were interviewed, content specific professional development may assist in this area as well, so that a one-toone school can ensure technological instructional delivery of pedagogy once or twice a week and ultimately daily.

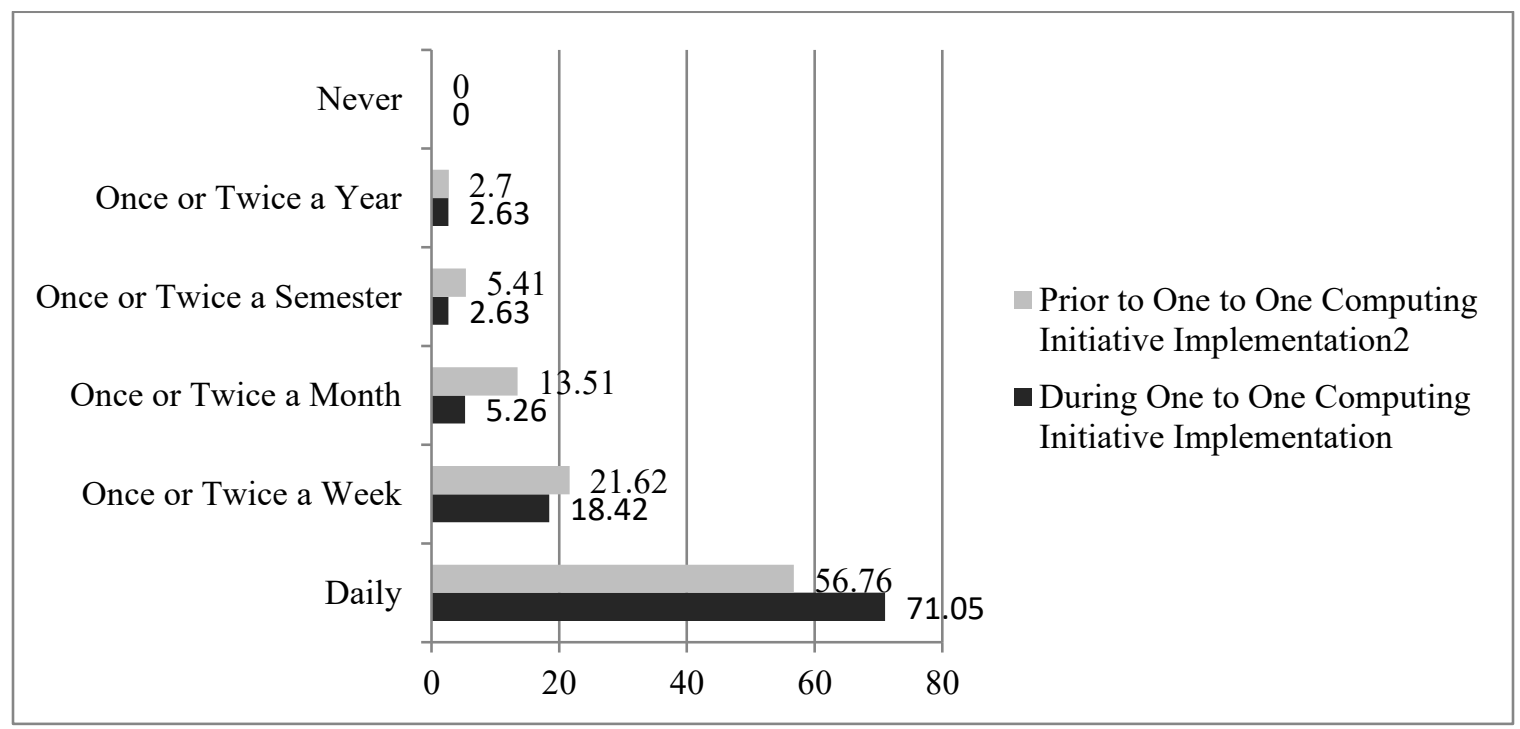

Figure 14. How Often Technology was used to Deliver Instruction.

Survey question 9 asked participants to indicate, based on time spent on 
professional development, how often technology was used to assess student learning.

Figure 15 highlights that prior to the one-to-one computing initiative, teacher participants stated that $8.11 \%$ never assess student learning using technology; $0 \%$ once or twice a year; $8.11 \%$ once or twice a semester; $21.62 \%$ once or twice a month; $37.84 \%$ once or twice a week; and $24.32 \%$ daily. After the one-to-one computing initiative, teacher participants stated that student learning was assessed using technology, with $2.70 \%$ stating never; $2.70 \%$ stating once or twice a year; $5.41 \%$ stating once or twice a semester; $2.70 \%$ once or twice a month; $48.65 \%$ once or twice weekly; and $37.84 \%$ daily.

As the data are considered, it is evident that the majority of the respondents have increased their usage of technology to assess student learning for both once or twice a week and daily. An interviewee stated, "if I knew of varied ways to use technology to access student learning I would use it daily." A respondent in the interview stated that if they were exposed to "professional development that focused more on the integration of technology based on a teacher's content area, then technology would be used more frequently to access student learning." After the one-to-one initiative was implemented, as Figure 15 indicates, there was a growth in the participants who responded that they used technology daily and once or twice a week to assess student learning.

Respondents may not see the full value of the time that was spent on professional development for the teaching of lessons, because the assessing of students will fall under that category with the schools being one-to-one. Continuous and content specific professional development that looks at technology based on the teacher content may prove to be extremely useful for the teachers as the school districts attempt to sustain a one-to-one computing initiative. The once or twice a week use of technology to assess student learning was the highest both before and after implementation; however, the trend 
continued where if the respondents were using technology prior to implementation, its use increased during implementation of the one-to-one computing initiative. Figure 15 illustrates an increase of technology being used to assess student learning by almost 14\% during implementation.

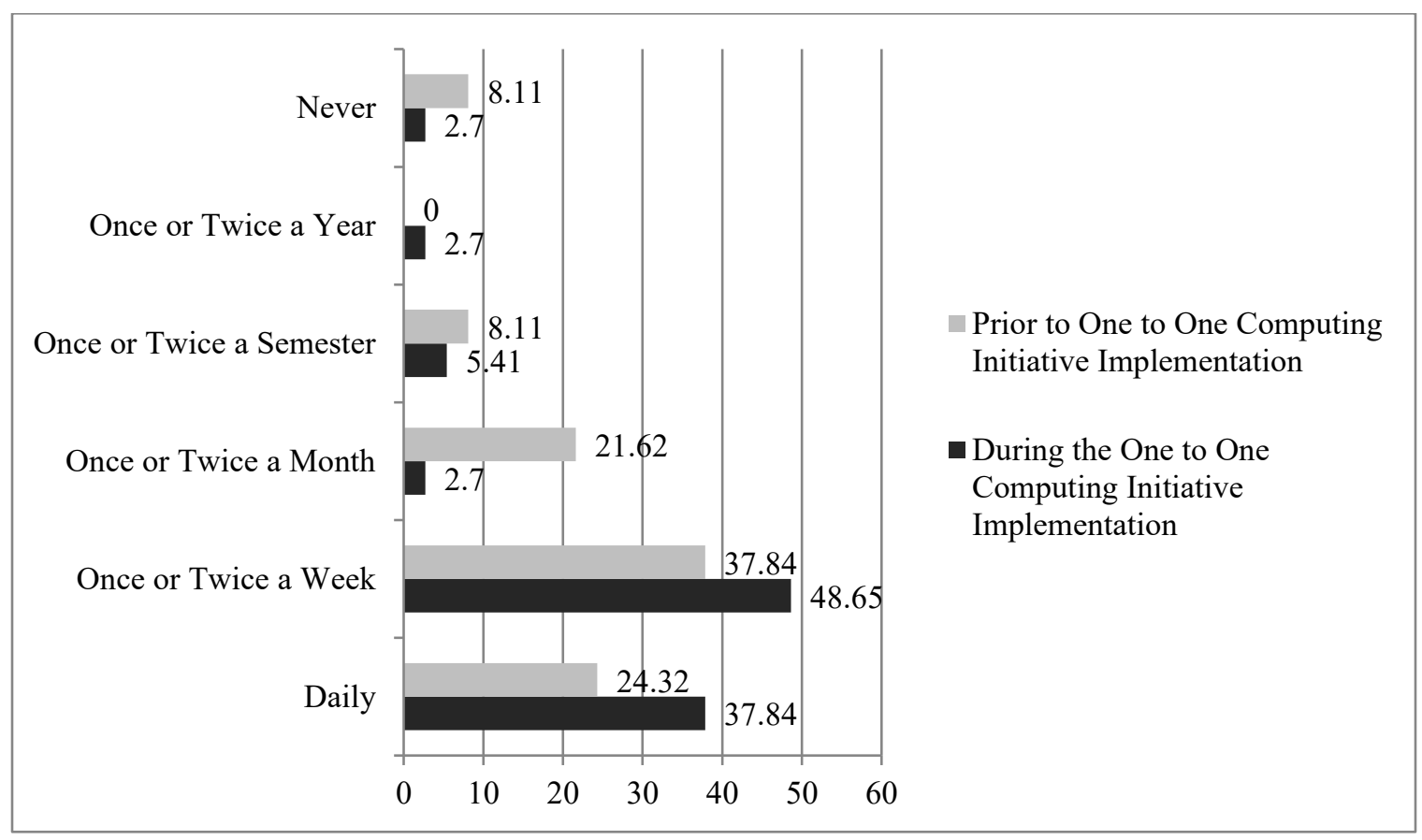

Figure 15. How Often was Technology used to Assess Student Learning.

Survey question 10 asked participants to indicate, based on the time spent in professional development, how often digital resources were used to supplement their existing textbook and/or curriculum. Figure 16 indicates that prior to one-to-one computing initiative implementation, teachers indicated that $45.95 \%$ used digital resources to supplement their existing textbook and/or curriculum; $27.03 \%$ indicated once or twice a week; $18.92 \%$ indicated once or twice a month; $2.70 \%$ indicated once or twice a semester; and $5.41 \%$ indicated never. A trend that continues here is the increase of technology use in the classroom during the one-to-one computing initiative 
implementation. More respondents indicated that during implementation, they increased their use of technology; in this case there is an increase from $45.95 \%$ prior to implementation to $65.79 \%$ after implementation for the daily use of technology to supplement the existing curriculum. During the implementation of the one-to-one computing initiative, the use of digital resources to supplement an existing textbook and/or curriculum daily grew to $65.79 \%$. Also, the number of participants who used digital resources to supplement their existing textbook and/or curriculum lowered from $18.92 \%$ before implementation to $5.26 \%$ following implementation. Participants in this category now used digital resources daily. It was evident that teachers are using digital resources to supplement their instruction. One observation is that there were respondents who indicated they never use digital resources to supplement their instruction. It goes back to Research Question 2 to ascertain if this was the case due to teacher perceptions of the value of the professional development that was spent on this for the teaching of their lesson.

Considering the data from the interview, it was found that time was not spent on content specific professional development, so the respondents who indicated never may have not been aware of digital resources that can be used to supplement existing textbooks and/or curriculum. Considering the data for Research Question 2, as was discussed earlier, respondents have indicated that content specific professional development may assist them with their pedagogy in the one-to-one environment. 


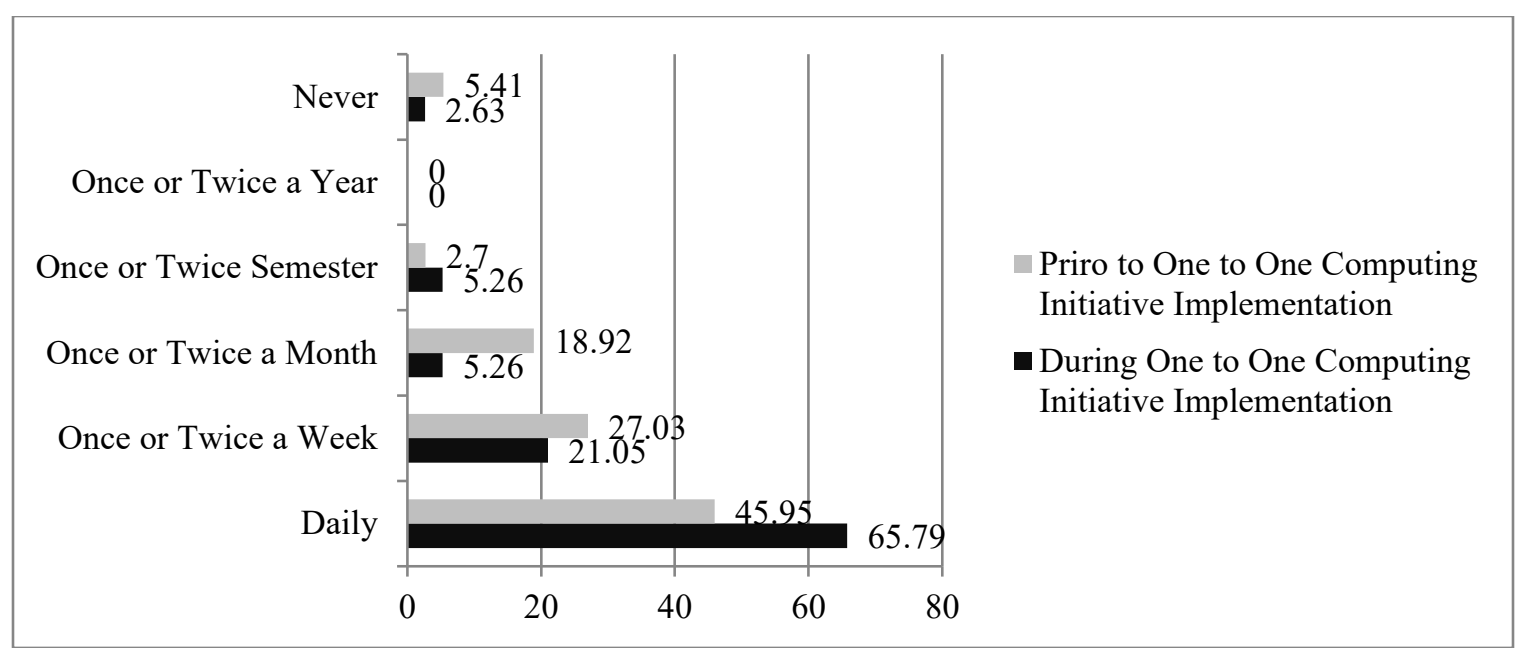

Figure 16. Participant Use of Digital Resources to Supplement Existing Textbook and/or Curriculum.

Survey question 11 asked participants to indicate, based on the time spent on professional development, how often technology was used to create and/or download presentations that can be utilized by students outside of the classroom. Figure 17 illustrates that prior to implementation, teacher participants indicated that $8.11 \%$ used technology to create and/or download presentations that can be utilized by students outside of the classroom; $0 \%$ indicated once or twice a year; $18.92 \%$ indicated once or twice a semester; $13.51 \%$ indicated once or twice a month; 40.54 indicated once or twice a week; and $18.92 \%$ indicated daily. After the implementation of the one-to-one computing initiative, $5.26 \%$ indicated they never used technology to create and/or download presentations that can be utilized by students outside of the classroom; $0 \%$ indicated once or twice a year; $7.89 \%$ indicated once or twice a semester; $13.16 \%$ indicated once or twice a month; $44.74 \%$ indicated once or twice a week; and $28.95 \%$ indicated daily. The trend of respondents continuing and showing improvements in the use of technology they were using prior to implementation continues. The daily use of 
technology to create or download presentations students can utilize outside of the classroom increased by $10 \%$, and once or twice a week increased by $5 \%$.

Figure 17 illustrates the use of technology to create and/or download presentations accessible to students grew by double digits from $18.92 \%$ to $28.95 \%$ during the one-to-one computing initiative implementation. On the other hand, only $44.75 \%$ of the teacher participants indicated the use of technology to create and/or download presentations that can be utilized by students outside of the classroom after implementation of a one-to-one computing initiative in comparison to $40.54 \%$ prior. This is also an area that content specific professional development that focuses on the use of technology for that pedagogy may be beneficial to teachers in a one-to-one learning environment. The aim is to ensure that teachers are maximizing all that is offered by incorporating technology into their classroom. As we consider the data, teachers are not currently doing that. It would be in the one-to-one computing initiative district's best interest to ascertain why the use of technology that increases student accessibility of content presentations is not higher. 


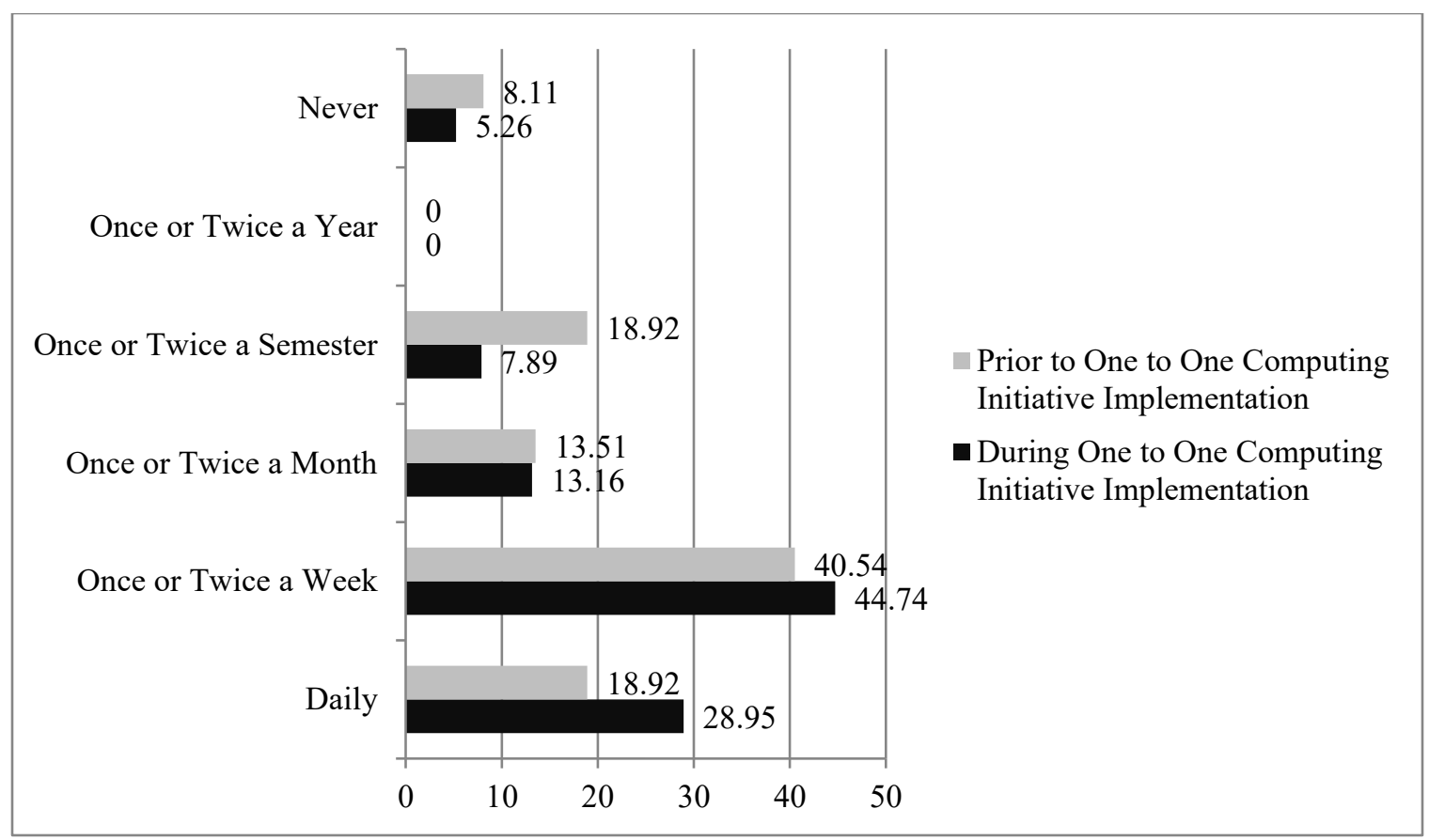

Figure 17. Participants Use Technology to Create and/or Download Presentations that Students can Access Outside of the Classroom.

Survey question 12 asked participants to indicate how often technology was used to differentiate or personalize instruction to meet the unique needs of individual students in the classroom. Figure 18 illustrates that prior to one-to-one computing initiative implementation, $5.41 \%$ of teacher participants indicated that technology was never used to differentiate or personalize instruction to meet the unique needs of individual students in the classroom; $0 \%$ indicated once or twice a year; $16.22 \%$ indicated once or twice a semester; $21.62 \%$ indicated once or twice a month; $32.43 \%$ indicated once or twice a week; and $24.32 \%$ indicated daily. Interviewees stated that there were no protocols at their schools that asked them to personalize instruction for students. This could be part of the reason for teachers not making a higher attempt to personalize instruction for students.

After the implementation of the one-to-one computing initiative, $5.26 \%$ of the 
teacher participants in the survey indicated that technology was never used to differentiate or personalize instruction to meet the unique needs of individual students in the classroom; $0 \%$ indicated once or twice a year; $5.26 \%$ indicated once or twice a semester; $23.68 \%$ indicated once or twice a month; $34.21 \%$ indicated once or twice a week; and $31.58 \%$ indicated daily. The trend that if respondents were using technology for an activity prior to implementation being improved on after implementation is evident for survey question 12 . Though the use of technology on a daily basis to differentiate or personalize instruction to meet the unique needs of individual students was $24.32 \%$, it increased to $31.58 \%$ during implementation. The increase was $7 \%$, but it was the only area that saw an increase after implementation of more than $2 \%$.

Interviewees were asked to indicate if there was a school or district protocol pertaining to the use of technology in their classroom. All respondents indicated that teachers and students had to sign for their laptops. In the case of students, they had to pay a fee in order to get their computing device; however, no interviewee indicated that they were expected by their school to personalize instruction for students. The TPACK model does state that teachers are expected to use their pedagogy, technology, and content to personalize instruction for their students. North Carolina State Board of Education (2017) also stated that teachers must "improve student performance in the public schools through the use of learning and instructional technologies" (p. 1). The digital learning competencies also state that teachers are to use technology to adjust instruction to meet the needs of the student population in their classroom. As we look at the data, school districts must remind teachers of the expectations of the North Carolina State Board of Education and the digital learning competencies in order to ensure that teachers use technology to personalize instruction for students. 


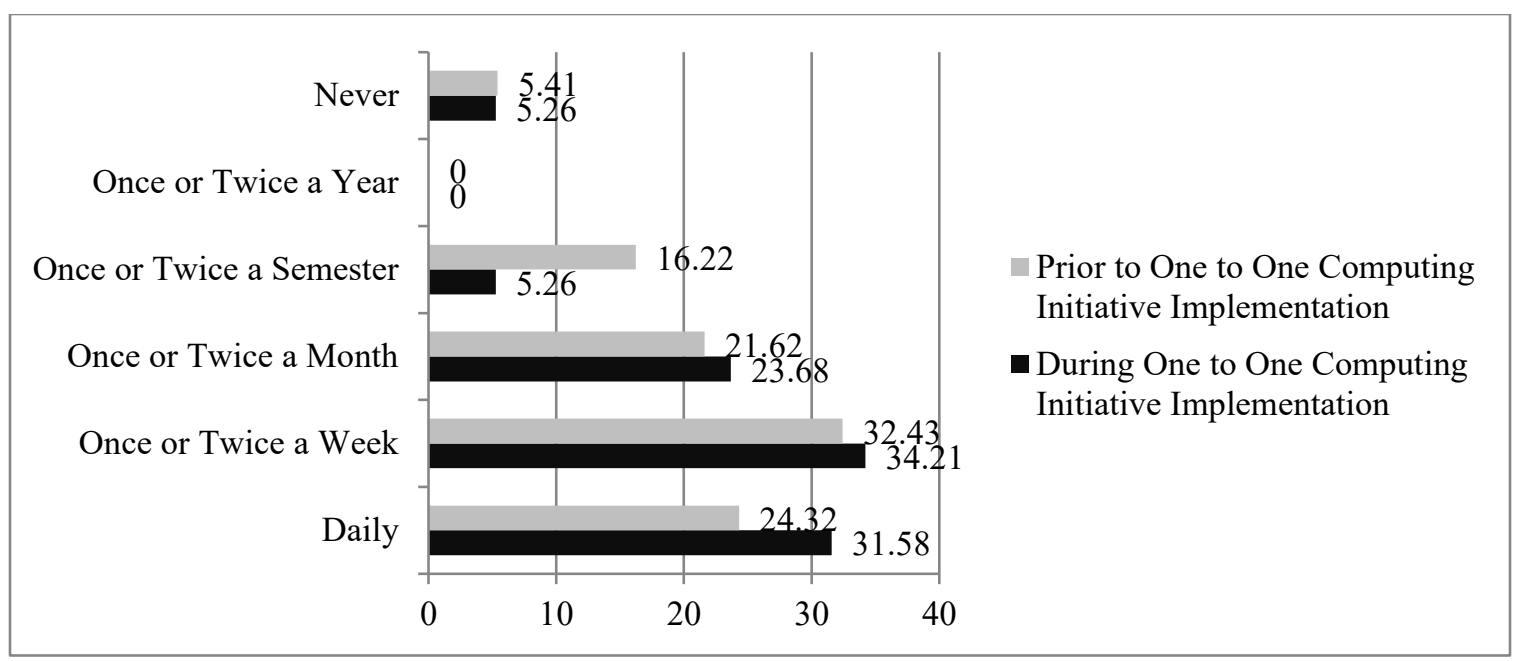

Figure 18. Participant Use of Technology to Differentiate or Personalize Instruction.

Survey question 15 asked participants to indicate how often students were asked to use digital technology to complete classroom learning assignments. Figure 19 illustrates that prior to the implementation of the one-to-one computing initiative implementation, teacher participants indicated that $10.81 \%$ never asked students to use technology to complete classroom learning assignments; $0 \%$ indicated once or twice a year; $10.81 \%$ indicated once or twice a semester; 18.92 indicated once or twice a month; 27.03 indicated once or twice a week; and $32.43 \%$ daily. During the implementation of the one-to-one computing initiative, teacher participants indicated that $2.70 \%$ never asked students to use technology to complete classroom learning assignments; $0 \%$ indicated once or twice a year; $2.70 \%$ indicated once or twice a semester; $2.70 \%$ indicated once or twice a month; $32.43 \%$ indicated once or twice a week; and $59.46 \%$ indicated daily. Figure 18 makes it evident that during the one-to-one computing initiative, participants increased the daily use of technology to complete classroom learning assignments, for daily use increased by $27 \%$. The once or twice a week use of technology by students to complete classroom learning assignments also increased by $5 \%$. In contrast, there are 
respondents who indicated they never used, or used only once or twice a semester, technology to complete classroom learning assignments. Content specific professional development may also seek to address this issue.

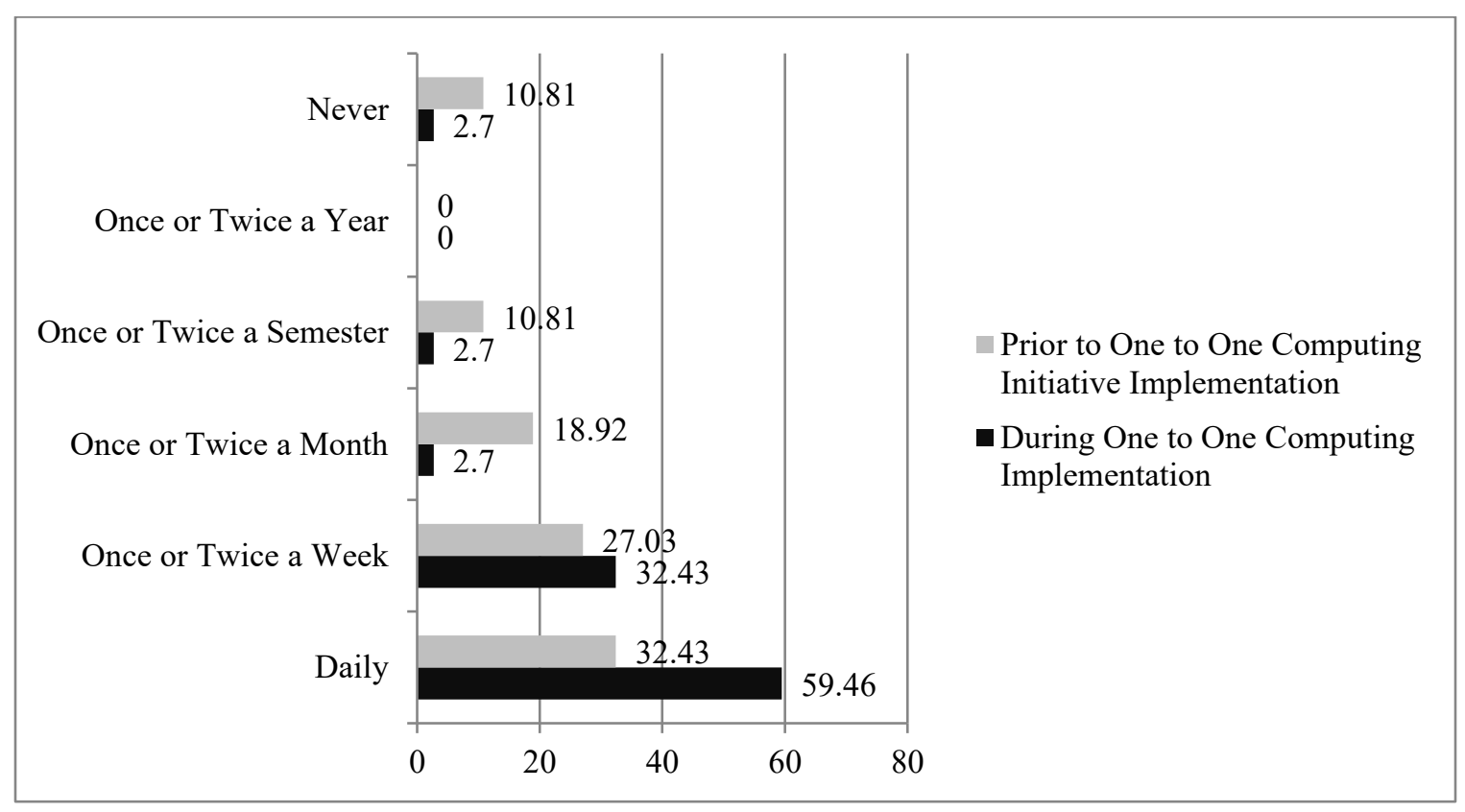

Figure 19. Students Use Technology to Complete Classroom Learning Assignments.

Research Question 2 asked teachers to state their perception of the time spent on professional development and its value for the teaching of their lesson. The common trend for Research Question 2 seems to be that teachers will need more professional development that is not only content specific but may also have to repeat some of the professional development that may have already been given. The fact is that there are still a number of areas where respondents indicated never using technology that may need to be corrected. USDOE (2010) stated that "effective teaching is an outcome of preparing and continually training teachers and leaders to guide the type of learning that we want in schools" (p. 5). If you are a one-to-one computing initiative school, student learning needs to be assessed online. All teachers should be expected to have students 
completing learning assignments online as well. As we consider Research Question 1, it was found that few teachers had students posting assignments online and communicating with a global audience. With continuous professional development about using online learning platforms, all respondents may become more comfortable with using technology as they teach lessons. As we review the data, there have been many improvements; but as we look at Research Question 2, respondents may need more time to be spent on content specific professional development, which could improve teacher perceptions of the value of technology as they teach their lessons.

\section{Research Question 3: What were teacher perceptions of the value of the time}

\section{allotted to teachers to have access to their devices prior to students having access to}

the similar device? The survey questions and interview questions that provided the data for guiding Research Question 3 are illustrated in Table 4.

Table 4

Survey Questions and Interview Questions for Research Question 3

\begin{tabular}{|c|c|}
\hline Survey Questions for Research Question 3 & Interview Questions for Research Question 31 \\
\hline $\begin{array}{l}\text { 4. How long have you had access to a } \\
\text { computing device that is similar to the one } \\
\text { that your students are using in the one-to- } \\
\text { one program? }\end{array}$ & $\begin{array}{l}\text { Teacher and Principal Interview Questions for numbers } 3 \\
\text { and } 4 \text { are different. They are listed concurrently. } \\
\text { Interview question } 8 \text { is the same for teachers and } \\
\text { principals. }\end{array}$ \\
\hline \multirow[t]{3}{*}{$\begin{array}{l}\text { 5. How long has your school undergone } \\
\text { professional development specifically } \\
\text { designed to prepare you for the } \\
\text { implementation of the one-to-one } \\
\text { Computing Initiative? }\end{array}$} & $\begin{array}{l}\text { 3. Does your school have any district or school wide } \\
\text { protocols as it comes to the using of technology in your } \\
\text { classroom? How long did teachers undergo professional } \\
\text { development to prepare them for the one-to-one } \\
\text { computing initiative? }\end{array}$ \\
\hline & $\begin{array}{l}\text { 4. Do you see any changes in student learning since the } \\
\text { implementation of one-to-one computing initiative at } \\
\text { your school? How do you get faculty members interested } \\
\text { in the use of technology in their classroom? }\end{array}$ \\
\hline & $\begin{array}{l}\text { 8. Is there anything that you want to add that I may not } \\
\text { have covered? }\end{array}$ \\
\hline
\end{tabular}

Research Question 3 focused on ascertaining data that would indicate teacher 
perceptions of the value of the time allotted to teachers to have access to their devices prior to students having access to the similar device. Fullan (2007) cited the need for professional development that involves workshops, courses, programs, and related activities that are designed presumably to provide teachers with new ideas, skills, and competencies that are necessary for improvement in the classroom. Survey question 4 asked participants to indicate how long they had access to a computing device that is similar to the one their students have prior to students having access to the same device. Figure 20 illustrates that $63.16 \%$ of the participants said they had access to their computing device prior to students for over a year. Only 5.25\% reported that they had their devices before students had a similar device for a semester. Figure 20 highlights that $73.69 \%$ of the participants had access to their computing device for at least 1 year.

\section{Teacher Access to Computing Device Prior to Students}

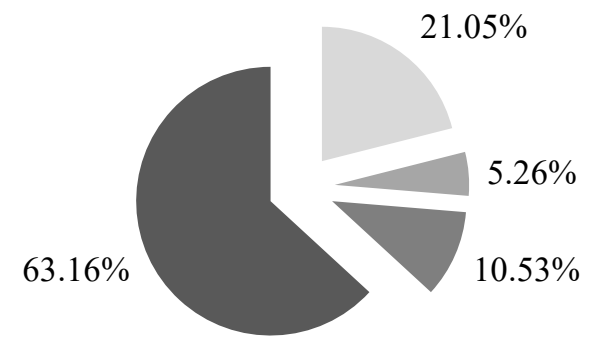

Less than one semester

- One semester

One year

More than one year

Figure 20. Length of Time Teachers had Access to Their Computing Device Prior to Students.

Interviewees indicated that they did not see the need for them to have access to their computing device prior to students. One teacher indicated that "the time was needed, so that teachers could get familiar with their device." The interviewees agreed 
that even though teachers had access to their device prior to students, there was really no need. Respondents during the interview all indicated there were times in their class that students had to show them how to use their computing device. One teacher said that technology is continuously being updated; therefore, "there must be continuous professional development to assist teachers to keep abreast with new technologies that they can use in their classroom."

Survey question 5 asked participants to state how long they had undergone professional development that was specifically designed to prepare the teachers for the implementation of the one-to-one computing initiative. Figure 21 illustrates that the majority of teachers reported they received 6 semesters or less of professional development, with $60.47 \%$ in these five categories; and $28.95 \%$ stated they received no professional development that was designed to prepare them for implementation of the one-to-one computing initiative.

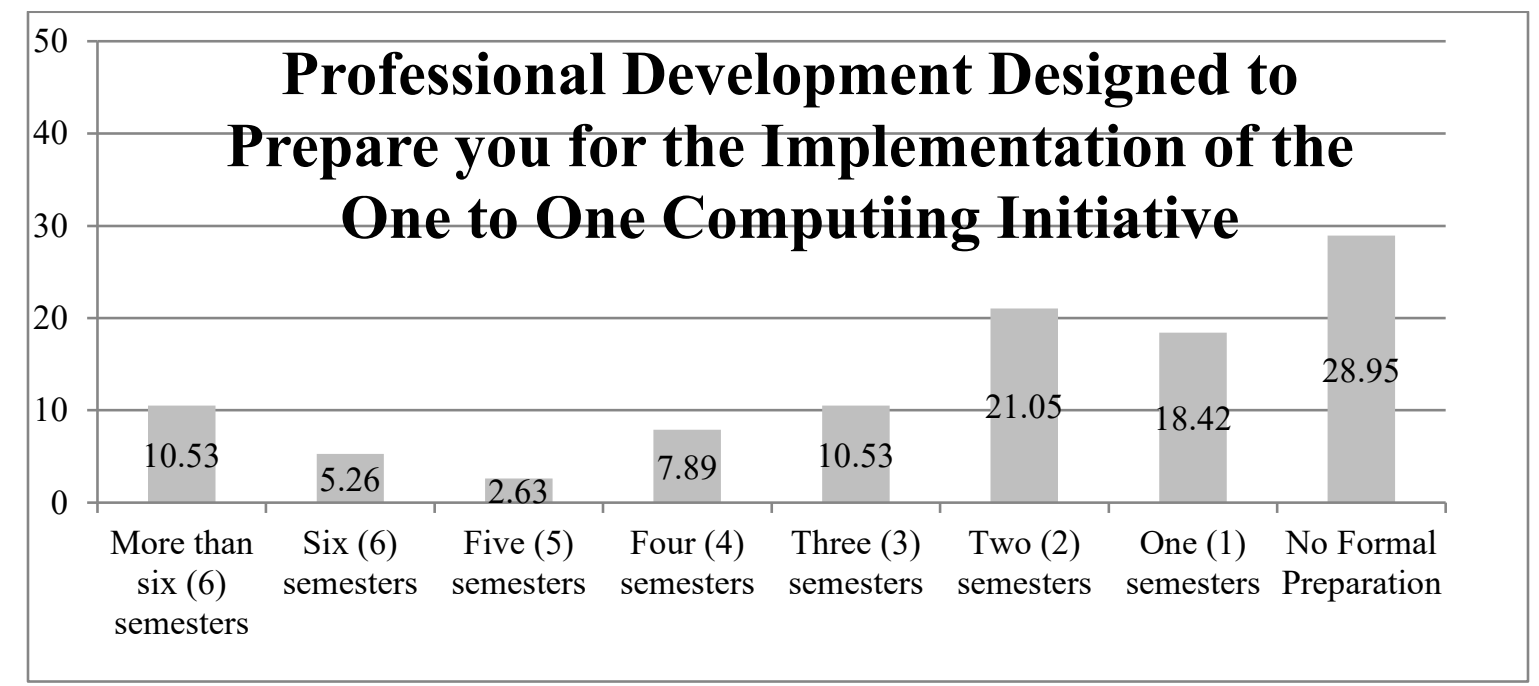

Figure 21. Length of Time Teachers had Professional Development in Preparation for One-to-One Computing Initiative.

Interview question 3 for principals asked them to state how long teachers had to 
undergo professional development to prepare them for the one-to-one computing initiative. In all cases, principals stated they were recently hired, so they could not directly say; but they speculated that professional development had occurred. No school mentioned that teachers had to sign a contract that explained the district's expectation of their teachers as they participate in the one-to-one computing initiative. It seemed as if teachers were left to their own professional judgment as to what they should or should not do as they implement a one-to-one computing initiative. An interviewee indicated that "there was nothing stated as to what is expected in terms of guidelines to inform teachers of how technology should be incorporated into their classes." As a result, many respondents felt that it was an option for them to be able to have students post assignments online, communicate with a global audience, use an online content platform to manage student data, and ensure that classroom materials are available online to students and parents. There were survey respondents who indicated they have not utilized a content management platform in the classrooms, nor do they expect students to collaborate online.

Interview question 4 asked participants to state if there was any evidence of changes in student learning that they noticed since the one-to-one initiative was started. All teachers said yes, they saw a change; but none gave any specific data as evidence of this. In the case of principals, interview question 4 asked how they got faculty members interested in the use of technology in their classroom. All stated that they modeled for their teachers during staff meetings. All school districts also had someone who was assigned as an instructional technology specialist. No school indicated they had a specialist who was solely serving their school.

Interview question 8 asked participants to state if there was anything they would 
like to add that was not asked during the interview. Interviewees reiterated that there was a need to dive into the use of technology that was content specific. School B had participants talk about the teachers wanting to feel a part of their district when it comes to the professional development days the district offers. The interviewees at the early college high school felt they were on their own, since their school calendar mirrored the local community college in the area and not the school calendar for the majority of the schools in their district. As a result, when the district has professional development days, the teachers at that school are not able to attend. They all stated the need to be able to attend and work with other teachers in their district on professional development days.

\section{Summary}

The participants in this study were teachers from three small nontraditional high schools that are located in the northern section of North Carolina. Each of these high schools already began a one-to-one computing initiative in their school districts. The population of teachers within the three high schools is 72. School A started its one-toone initiative in August 2014 and has a population of 47 teachers (Traditional High School). School B started its one-to-one laptop initiative in August 2012 and has a population of 13 teachers (Early College). School C, which is one of nine schools in this school district, started its one-to-one laptop initiative in August 2010 and has a population of 12 teachers (New Technology High School).

Teachers were asked to complete a survey, and nine participants were interviewed as well. Based on the responses that were gathered on the survey and during the interview process, the researcher was able to identify teacher perceptions of professional development and its role in sustaining a one-to-one computing initiative. 


\section{Conclusion}

Based on the data that have been analyzed in this chapter, various conclusions are made in Chapter 5. There is a more in-depth look at the role of quality professional development after the implementation of a one-to-one computing initiative, professional development and its value for the teaching of lessons, and the value for teachers having their devices prior to students having a similar device. There are also suggestions and implications for future practice that school leaders can utilize as they drive one-to-one computing initiatives in their districts. There are also recommendations for future research, so there can be further analysis into the successful sustainment of one-to-one computing initiatives. 


\section{Chapter 5: Discussion}

\section{Overview}

One-to-one computing initiatives have become widespread in the country and are evident in many school districts. School districts are looking for ways to ensure that students are technologically savvy as they try to keep abreast of the technological advances in society. The one-to-one learning initiative is defined in this study as a computing device that school districts have students using in their classrooms during school hours. Many districts also offer students the opportunity to take the computing device home, so students have access to the computing device after school hours. Of course, one-to-one computing initiatives do involve a financial investment on the part of the school district.

This study was conducted to examine teacher perspectives of the professional development on the sustaining of a one-to-one computing initiative at the high school level. This research provides a glimpse of the ways in which professional development can help sustain a one-to-one computing initiative. This study also discussed some of the instructional changes that must be considered in order to sustain one-to-one computing initiatives. The time allotted for professional development for teachers prior to the implementation of a one-to-one computing initiative, the professional development that was afforded to teachers during implementation, and teacher perceptions of the worth of the professional development they were given were examined. This research provides qualitative data that can be used to lay the foundation for what may be needed in order sustain one-to-one computing initiatives as it relates to professional development for teachers. This research also provides data that may assist school districts to ensure that teachers use the TPACK model as they teach their pedagogy and integrate technology 
into their classroom. There will be recommendations for not only ways to sustain a oneto-one computing initiative, but also for future research.

\section{Findings}

There were a number of findings that were evident when the data were analyzed. The findings and analysis of the data for this research are discussed based on the research questions that guided this study.

\section{Research Question 1}

What are teacher perceptions of the quality of professional development after the implementation of a one-to-one computing initiative?

"Professional development refers to many types of professional experiences that are related to an individual's work" (Mizell, 2010, p. 3). The data in this study indicate that teachers were provided with professional development prior to and during implementation. The data also indicated that only $21.06 \%$ of the teachers who participated in the survey had less than 1-2 years of being a certified teacher. With $42.11 \%$ teachers stating they had 11-15 years of teaching experience, it was found that only $2.63 \%$ of participants stated they were a novice when it came to using technology. Half of the teachers stated they were at the intermediate level when it comes to computer usage, with $44.74 \%$ indicating that they were at the advance level. In a study that was designed to examine the relationship between professional development in literature and self-reported change in teachers, Garet et al. (2001) found that the notion that external ideas alone will result in changes in the classroom and school is deeply flawed as a theory of action. Similarly, it would be deeply flawed to think that because teachers selfreported they are intermediate or advanced when it comes to technology, they are able to incorporate technology seamlessly into their instruction. 
Additionally, ISTE, who released NETS-T, believed that teachers who continuously improve their professional practice, model lifelong learning, and exhibit leadership in their school and professional community, felt comfortable with technological tools as stated earlier. Teachers also "contributed to the effectiveness, vitality, and self-renewal of the teaching professional of their school and community" (USDOE, 2010, pp. 1-2). In this study, it was evident that even though teachers selfreport being proficient with technology, they needed additional support when it came to utilizing technology in their classroom. Content specific professional development was one of the ways teachers in this study felt that the quality of the professional development after implementation of a one-to-one computing initiative can be improved and ultimately sustained.

\section{Content Specific Professional Development}

Research Question 1 in this study brought to the fore that teachers believed quality professional development specific to the content being taught would aid in developing their pedagogy. Interview question 6 asked participants to indicate the value of specific professional development in preparation for the one-to-one computing initiative. The data for survey question 6 illustrated that $44.74 \%$ of the participants indicated that learning to implement the technology within instruction was significant to their preparation as it relates to the professional development that was offered as the district prepared for the one-to-one computing initiative. Survey question 6 also illustrated that learning to use hardware applications, learning to use the software applications, and learning to use a content management platform were all rated as being good to the teachers' value as their school prepared for the one-to-one computing initiative; however, respondents were of the view that in order to sustain the one-to-one 
computing initiative, it would be imperative that professional development be content specific.

Even though only nine of the participants participated in the interview, question 6 asked participants to identify what type of professional development would be more beneficial as the school sustains a one-to-one computing initiative. A common response for the interviewees was that there was a need to have quality professional development that focused on showing teachers how to use the technology that was specific to their pedagogy. These data further support Research Question 1, for teachers were asked to indicate their perception of the quality of professional development of a one-to-one computing initiative. School districts that have a one-to-one computing initiative that has been or will be implemented may want to ensure that professional development is content specific, so teachers are able to see how they can incorporate technology for their pedagogy. As stated by the USDOE (2010), "the best form of technology professional development is one that allows teachers to experience technology firsthand" (p. 5). Firsthand experience is one that ensures that professional development is based on the teacher's content. As Greaves et al. (2010) stated, “effective school leaders provide ongoing, embedded professional development in order to ensure best practices for new century education" (p. 52). Participant perceptions of quality professional development after the implementation of a one-to-one computing initiative were that in order for their district's one-to-one computing initiative to be sustained, it would be extremely beneficial to have pedagogy-driven professional development. As a result, teachers would be able to relate the information shared in the professional development with their pedagogy.

"Teachers are more likely to use technology in their classrooms if they feel 
comfortable and confident with it, and if they see the purpose for it" (Annable, 2013, p. 174); thus, as we attempt to sustain a one-to-one computing initiative, professional development for teachers needs to be "ongoing on the job application of best practices, reflection with peers, and collaboration on how to implement theories in the classroom" (Greaves et al., 2010, p. 52). In order to ensure that teachers are comfortable with technology in their classroom, the data for this study show that teachers are of the perception that content specific professional development would be beneficial (Bandura 1977). Content specific professional development may also assist teachers to be able to effectively use the TPACK model as they incorporate technology into their lessons.

\section{Willingness to Use Technology}

It can be inferred based on the data that respondents were willing to use technology in the classroom. A number of the survey responses illustrated that if the respondent was using technology prior to implementation, there was an increase in the use of technology after implementation. The data for survey question 13 indicated that prior to the implementation of the one-to-one computing initiative, $8.11 \%$ of the respondents created a learning activity designed to challenge students to think critically once or twice a semester; $13.51 \%$ indicated once or twice a month; $45.95 \%$ indicated once or twice weekly; and 29.73 indicated daily. After the implementation of the one-toone computing initiative, $2.63 \%$ indicated that they created a learning activity designed to challenge students to think critically once or twice a semester; $7.89 \%$ indicated once or twice a month; $50 \%$ indicated once or twice a week; and $39.47 \%$ indicated daily. While the overall percentage of the creation of a learning activity designed to challenge students to think critically increased during implementation, the daily use increased by nearly $10 \%$. Similarly, prior to the one-to-one computing initiative implementation, teacher 
participants indicated for survey question 14 that $29.73 \%$ never used a class web page or used a content management platform where students can access learning materials and/or turn in assignments in a digital format; $2.70 \%$ indicated once or twice a year; $10.81 \%$ indicated once or twice a semester; $10.81 \%$ indicated once or twice a month; $21.62 \%$ once or twice a week; and $24.32 \%$ indicated daily. During the implementation of the one-to-one computing initiative, the data indicate that teachers had increased their use of technology to create a web page or content platform that students can use to access class materials and/or submit their assignments. The daily use of technology to create a web page or content platform that students can use to access class materials and/or submit their assignments increased by $13.52 \%$ during implementation. Once or twice a week also increased by $8.11 \%$. In a study of one-to-one programs in western Massachusetts, Bebell and Kay (2010) found that "it is impossible to overstate the power of individual teachers in the success or failure of one to one computing initiatives" (p. 47). This study indicated that respondents wanted to incorporate technology into their classroom and showed several teachers increased usage during implementation. As we consider the data, $95 \%$ of the teachers indicated that they had a positive self-efficacy when it came to their competency with technology. This is further supported by their willingness to use technology during implementation.

\section{Value of Professional Development}

Research Question 1 allowed teachers to indicate their perception of the quality of professional development after the implementation of a one-to-one computing initiative, in particular their value of the various types of professional development they were given. Respondents indicated that learning to use software applications and programs was good to their value as they prepared for the one-to-one computing initiative. Learning to use 
content, management, and delivery platforms for their instruction was given the highest percentage as it being good to the respondent's value. Interestingly, it was professional development that taught participants how to implement technology within instruction that received the highest value rating by participants. Respondents stated that learning to implement the technology within their classroom instruction was significant to their value as the district prepared participants for the one-to-one computing initiative. Yoon, Duncan, Lee, Scarloss, and Shapely (2007) reviewed over 1,300 studies to ascertain how professional development affected student achievement, and they found that the advancement of teacher understanding of their pedagogy is achieved through professional development. On the other hand, teachers should not only "become familiar with hardware and software [related to their computing device], but they need time to review available resources that would be more relevant to their classroom" (Greaves et al., 2010, p. 52).

Penuel (2006), who synthesized the findings from 30 separate studies of one-toone initiatives which included Henrico County in Virginia, Cobb County in Georgia, and the SRI International Researchers who were under contract with the USDOE, went on to state that teachers reported that their technology professional development sessions typically focused on the procedural use of the software. On the other hand, learning how to effectively use the hardware for classroom instruction was more critical (Penuel, 2006). This further supports the findings in this study that teachers perceived there would be value to professional development that is content specific. Penuel's findings indicated it was more critical to learn how to effectively use the hardware for classroom instruction, which is parallel with the findings in this study. It gives credibility to what respondents in this study have indicated. Interviewees stated that learning how to use the 
hardware as it relates to their content should be done in professional development.

Interviewees also felt that using the technology for testing and accountability was useful to them but felt that professional development that focused on content specific instruction would be more beneficial.

Similarly, in this study, teachers also indicated that much of the professional development prior to and during implementation of the one-to-one computing initiative focused greatly on showing teachers how to use technology for testing purposes. While teachers did see the value in this, they also indicated there was a greater need to ensure that, as high school teachers, they have professional development that focuses more on using the technology by content; therefore, teachers want to be able to teach students how to "acquire and apply new knowledge" (Trilling \& Fadel, 2009, p. 9). Thus, "teacher preparation through quality [content specific] professional development can be statistically significant" (Shapely et al., 2009, p. 33). This is definitely the case in this study, because the common trend for respondents was that they would like to see professional development that is content specific. As we consider the data, respondents indicated that vicarious experiences discussed by Bandura (1977) would be extremely beneficial to them, and they would improve their self-efficacy if they were shown how to use technology based on their content.

\section{Research Question 2}

What were teacher perceptions of the time spent on professional development and its value for the teaching of their lessons?

Survey question 6, which asked respondents to rate the value of specific types of professional development that prepared them for the one-to-one computing initiative, indicated that participants felt that learning to use hardware, software, and content 
management platforms was good to their value. The data indicated that respondents found the time that was spent on professional development valuable for the teaching of their lessons. Teachers who participated in the interviews stated that they felt that the time that was spent in professional development prior to implementation was valuable for the teaching of their lessons (Bandura 1977). The data also indicated that the respondents sought to make adjustments to their instructional practice and brought to the fore a greater role for instructional coaches. Survey question 7, which asked how often respondents used technology to plan for instruction, illustrated an increase in the daily use from $51.35 \%$ prior to implementation to $68.42 \%$ during implementation. Similarly, survey question 8 , which asked how often did respondents use technology to deliver instruction, indicated that daily use increased from $56.76 \%$ prior to implementation to $71.05 \%$ during implementation. Survey questions 7 and 8 both indicated increases in the use of technology based on the time that was spent in professional development prior to implementation. On the other hand, survey questions 7 and 8 also indicated there were respondents who used technology once or twice a year to plan for and deliver instruction. Respondents are willing to make adjustments to their instructional practice; however, instructional coaches may be useful to assist all teachers to use technology effectively in their classroom since they can offer professional development that caters specifically to the planning and delivering of instruction based on content.

\section{Adjustments to Instructional Practice}

Research by Drayton et al. (2010) indicated that "a lack of professional development, especially in the form of teacher collaboration to develop best practices within a school, becomes a barrier to effective integration of computer and Web resources in the classroom" (p. 41). There are a lot of factors that would affect the 
sustainability of one-to-one computing initiatives; however, "a number of teachers changed the practices to accommodate the opportunities of increased technology access" (Bebell \& Kay, 2010, p. 6; Drayton et al., 2010; Shapely et al., 2009; Suhr et al., 2010). The respondents in this survey did indicate a willingness to adjust their instructional practices in the classroom. The leaders who were a part of this study also indicated they model technology use for their teachers during faculty and staff meetings. Research Question 2 focused on teacher perceptions of the time spent on professional development and its value for the teaching of their lessons. Teachers saw a value for professional development. The data illustrated that respondents made adjustments after implementation in many instances that led to an increased use of technology in their classroom. The data show that respondents valued the time that was spent on professional development. Participants indicated there was a need to sustain the professional development they were getting and ensure that professional development was content specific.

Respondents indicated they used technology to plan their instruction on a daily basis, which increased from $51.35 \%$ prior to one-to-one computing implementation to $68.24 \%$ after implementation. Respondents also indicated that technology was used to deliver instruction, which also saw an increase from $56.76 \%$ prior to implementation to $71.05 \%$ during implementation. There was also an increase in the use from $45.95 \%$ prior to implementation to $65.79 \%$ when it came to the daily use of digital resources to supplement the existing textbook and/or curriculum that was available to respondents.

Respondents indicated that students were asked on a daily basis to complete classroom learning assignments which indicated growth from $32.43 \%$ prior to the implementation of the one-to-one computing initiative to $59.46 \%$ after the one-to-one 
computing initiative. The data in this research indicate there is a need for teachers to clearly know how to use technology in terms of their district's expectations. It would also be beneficial for teachers to be given ongoing surveys so districts can ascertain teacher needs and address them accordingly.

\section{Role of Instructional Coaches}

All the school leaders at the different schools also indicated that teachers have instructional coaches who model for them. The problem in one school was that the instructional coach had to facilitate the entire district. Another school leader stated that the instructional coach serves all the teachers, but all teachers teach different subjects. The instructional coach could speak to the use of technology but could not specifically look at the pedagogy of the teacher and relate the use of technology to a specific course. This confirms there is a need for instructional coaches who are not only able to focus on the school that has implemented the one-to-one computing initiative, but also are trained in specific pedagogy and are able to offer professional development that focuses on implementation of technology based on specific courses. As Research Question 2 discussed, participants saw a value for the time spent on professional development and its role in the teaching of their lessons. They went on stress that professional development must cater to their specific needs by being pedagogically driven.

Corkin et al. (2016) surveyed 80 K-12 mathematics teachers from urban school districts in Florida before and after a 3-week professional development program about TPACK. Corkin et al concluded that not only do teachers need knowledge of how to incorporate technology for instruction, but it is imperative that believe they have the ability to use technology effectively (Bandura, 1977; Corkin et al., 2016). Corkin et al. stated that teachers wanted to use technology in their classrooms, but they wanted to 
develop self-efficacy about its use in order to confidently incorporate technology into their lessons. Corkin et al. also stated that modeling for teachers is needed in order for them to incorporate technology effectively in their classrooms (Bandura, 1977).

If teachers have instructional coaches to whom they are assigned based on content, this may also improve the self-efficacy of teachers. Bandura (1977) talked about the importance of social persuasion to build self-efficacy. As a result, teachers with instructional coaches who can offer professional development that focuses on the content of the course may provide feedback on performance that may improve teacher selfefficacy and improve the integration of technology into the teachers' content.

"Teacher preparation through quality professional development can be statistically significant" (Shapely et al., 2009, p. 33). Research by Drayton et al. (2010) indicated that "a lack of professional development, especially in the form of teacher collaboration to develop best practices within a school, becomes a barrier to effective integration of computer and Web resources in the classroom" (p. 41). In an effort to sustain a one-to-one computing initiative, it is important that teachers have an opportunity to work with instructional coaches or instructional technology specialists who can offer professional development that focuses on the content of the course. In an effort to sustain a one-to-one computing initiative, it would be beneficial to a school district if they spent time to ensure that teachers are able to effectively use TPACK and the North Carolina digital learning competencies. This could ensure that teachers are able to integrate technology effectively in their classroom, which can be modeled for them by an instructional coach. 


\section{Teacher Expectation Contracts}

Respondents also felt that the time that was spent on professional development prior to implementation was good, as is indicated in the data for survey question 6 . Respondents also felt that the time spent on professional development during implementation needed to be content specific, as was stated in the interviews. Principals who participated in the interviews stated that they modeled technology use for teachers during staff meetings as a professional development session during implementation. None of the principals stated how this was modeled, but teachers stated in their interviews that the modeling done for them during staff meetings by their school principal was inadequate. A teacher went on to state that they would have preferred that the time spent on professional development during implementation be content specific in order to assist them with how technology should be used for their pedagogy.

Students and parents in all schools were expected to sign a contract with the school district that governs the expectations for the repairs of computing devices. It is also important that teachers not only sign a contract that states what they are responsible for when it comes to the repair for their computing device, but they should also sign a contract that directly outlines the expectations of teachers as they use the computing device in their classroom. Many principals, such as the principals who participated in the interviews for this study, may think that modeling technology use during staff meetings is useful; however, teachers stated during interviews that their principal modeling technology use was not adequate. Therefore, it may be useful for school districts to have an expectation for the use of the computing devices once they are in the hands of the teachers and principals. Teachers and principals should be clearly aware of the fundamentals of what is expected in the classroom and schools once they have signed for 
their computing device.

It is important that the availability of learning materials for the classroom for all students, parents, and stakeholders be one of the clearly outlined expectations. Contracts should clearly outline that not only should teachers use Rapid Identity or any other district specified web platform, but they must also set up a class web page in Canvas if the school district pays for that service, or Google classroom, or any other recommended web page for the district. When teachers are aware of the expectations for the use of technology in their classroom, the likelihood of the inappropriate use of technology or no use at all may diminish. Marzano and Waters (2009) talked about the fact that ensuring uniform integration of technology in every class implies a clearly articulated, districtwide approach to instruction. They went on to state that this is a key trait of highperforming districts as well. The signing of a contract that clearly outlines expectations at a one-to-one computing school would be beneficial to a school that is implementing and sustaining a one-to-one computing initiative.

\section{Research Question 3}

What were teacher perceptions of the value of the time allotted to teachers to have access to their devices prior to students having access to a similar device?

The data show that respondents did place a significant value on having access to their devices prior to students. An interviewee indicated that having access to their device prior to students was beneficial but was also of the belief that students could have had their device as well. Storz and Hoffman (2013) conducted a study that focused on a Midwestern urban middle school that had "emphasis on how teachers can use technology in their teaching" (p. 13). Their study found that some teachers believed it would have been great if "they had access to their laptops prior to students" (Storz \& Hoffman, 2013, 
p. 13). Respondents in this study preferred to have professional development that was content specific and felt that this would have been more beneficial than having access to their devices before students.

Majeski (2013) examined middle school teacher and principal perspectives as they relate to the use of technology in the classroom and schools. He found that "there needed to be greater access to laptops prior to the using of the technology in their schools" (Majeski, 2013, p. 56). "It is important that teachers engage with the technology prior to them being asked to incorporate the technology in their classroom with students" (Gulamhussein, 2013b, p. 1). The data in this study agree with research by Gulamhussein (2013a). Respondents were of the belief that they needed professional development that served to offer pedagogically driven professional development; however, participants did not think that simply having the computing devices prior to students would be beneficial.

Similarly, Higgins and Russell (2003), who conducted a survey into the types of professional development that teachers thought were beneficial in integrating technology in the classroom, reported that the majority of the high school teachers in their study indicated that basic professional development designed to teach teachers to manage their computers was not necessary because they preferred to be taught how to use the devices in their lessons. Participants in this study did find the value of learning to use the hardware and software to be of good value as was stated in the data for survey question 6 . Interviewees also stated that professional development that focused on showing them how to use the technology in their classroom was of significant value to them. As was stated earlier, this was quite evident when one looks at the response for survey question 6 which indicated that respondents stated that professional development that focused on learning to implement that technology within instruction to be the greatest value to 
teachers.

\section{Recommendations for Sustaining a One-to-One Computing Initiative}

Based on the data collected in this study, there are a number of recommendations school districts should consider as they implement and ultimately sustain a one-to-one computing initiative. The recommendations are not prioritized, and they are as follows:

- Offer professional development prior to and during implementation of a oneto-one computing initiative that is pedagogically driven. Teachers will need to be exposed to professional development that is based on incorporating the technology into their instruction based on the course they teach.

- Offer professional development to administrators and teachers about the hardware and software components of the computing device.

- Conduct surveys of teachers prior to and during implementation of a one-toone computing initiative in order to ascertain their ability to use the hardware, software, and technology for their instruction and to identify any needs teachers may have.

- It is recommended that schools that have a one-to-one computing device have instructional coaches who are able to provide course specific professional development to teachers. It would be preferred that the coach or coaches be someone who is assigned to that school.

- Ensure that teachers sign contracts for not only their computing device but also contracts that clearly outline expectations of technology use for classroom instruction.

- Encourage professional development that will allow teachers at the school to collaborate irrespective of their pedagogy. This could ensure that best 
practices for the use of technology for instruction can be shared.

- Offer professional development for school administrators at schools with a one-to-one computing initiative, so they are able to determine if technology is being implemented with fidelity in the classrooms at their school.

\section{Recommendations for Future Research}

This study involved three high schools in a northern, rural section of North

Carolina. It would be interesting to include other schools that may be located in an urban area to see the response. It would also be of value to conduct a study that involved both rural and urban locations so a comparison could ensue. Future research can also look at the impact that consistent professional development can make at different times during the school year. This study looked at how quality professional development can sustain a one-to-one computing initiative. Another study can track the professional development over a given time and see if there is a direct correlation between consistent professional development and the sustaining of a one-to-one computing initiative.

It was evident in this study that all the schools had professional development prior to the implementation of the one-to-one computing initiative. It may be worth studying schools that had no professional development prior to implementation to see if the responses would be similar. Also, this study focused on the high school level; it may be interesting to look at middle schools or elementary schools in order to ascertain if the results would be similar as well.

\section{Summary}

At the state level in North Carolina, teachers in all grades are expected to incorporate computer skills into their classroom; therefore, technology skills should be seen as being a seamless integration. The model that is used in North Carolina is the 
TPACK model. Teachers in North Carolina are expected to ensure that as they teach their pedagogy, they use technology seamlessly.

North Carolina State Board of Education (2017) stated,

The NC State School Technology Plan shall be a comprehensive State implementation plan for the uses of funds from the State School Technology Fund and other sources to improve student performance in the public schools through the use of learning and instructional technologies. (p. 1)

Thus, schools are expected to use the funds that are afforded to them by the state to ensure that the TPACK model is followed in schools. The result of the use of technology is to ensure that, as North Carolina State Board of Education (2017) continued, "the use of technologies challenges State, federal, and local educational performance" (p. 1). The ultimate aim is to "effectively integrate technologies that are compatible with the standard course of study, the State assessment program, and related student data management” (North Carolina State Board of Education, 2017, p. 1).

Without a doubt, "our educational context has changed and a new context demands new things" (Prensky, 2011, p. 2). Rather than try to insert knowledge into our students' brains, “today's teachers need to find ways to create $21^{\text {st }}$ century citizens who parrot less and think more" (Prensky, 2011, pp. 2-3); however, as teachers attempt to find ways to create a class environment that will teach students to be ready for the future, they need the support that will show them how to incorporate lessons that are technologically enhanced. In order for instruction to be effective, lessons must be designed to address the needs of each individual student (Conole \& Fill, 2005).

As a result, it is important that we not only continue to implement one-to-one computing initiatives, but school districts must ensure that professional development is 
offered prior to and during implementation in order to ensure that the one-to-one computing initiative is sustained. As this study has shown, teachers want professional development that will assist them in being able to use technology appropriately in their classroom as their school district implements and sustains a one-to-one computing initiative. The results of this study shed some light on the importance of professional development prior to and during implementation of a one-to-one computing initiative that can be utilized by district and school leaders as they consider future one-to-one computing initiatives. 


\section{References}

Apple Classrooms of Tomorrow-Today. (2008, April). Apple Classrooms of Tomorrow—Today: Learning in the 21st century. Retrieved February 8, 2018, from http://cbl.digitalpromise.org/wpcontent/uploads/sites/7/2017/07/ACOT2_Background.pdf

Annable, C. J. (2013). An investigation of laptop classrooms and the teaching and learning of mathematics (Doctoral Thesis, University of Toronto, Canada). Retrieved from https://tspace.library.utoronto.ca/handle/1807/35766

Bandura, A. (1997). Self-efficacy: The exercise of control. New York: W.H. Freeman \& Co.

Bebell, D., \& Kay, R. (2010). One to one computing: A summary of the quantitative results from the Berkshire Wireless Learning Initiative. Journal of Technology, Learning, and Assessment, 9(2), 1-60.

Bebell, D., \& O'Dwyer, L. (2010). Educational outcomes and research from 1:1 computing settings. The Journal of Technology, Learning, and Assessment, 9(7), 1-16. Retrieved February 15, 2018, from https://ejournals.bc.edu/ojs/index.php/jtla/article/view/1606/1463

Birch, M. (2017). 12 most important technologies since 1990. Retrieved March 25, 2018, from https://www.alleywatch.com/2014/11/12-most-important-technologiessince-1990/

Blank, R., \& De las Alas, N. (2010). Effects of teacher professional development on gains in student achievement: How meta analysis provides scientific evidence useful to education leaders. SREE Conference Abstract Template, 1-6. Retrieved January 20, 2018, from https://files.eric.ed.gov/fulltext/ED514190.pdf 
Borthwick, A., \& Pierson, M. (2008). Transforming classroom practice: Professional development strategies in educational technology. Eugene, OR: International Society for Technology in Education.

Castle, K. (2012). Early childhood teacher research: From questions to results. New York, NY: Routledge

Cheong, C., \& Cheung, W. (2008). Critical thinking skills: A case study in a Singapore secondary school. Australasian Journal of Educational Technology, 24, 556-573.

Conole, G., \& Fill, K. (2005). A learning design toolkit to create pedagogically effective learning activities. The Open University, 1-17. Retrieved April 5, 2018, from https://oro.open.ac.uk/11725/1/conole-2005-08.pdf

Corkin, D., Ekmecki, A., White, C., \& Fisher, A. (2016). Teachers' self-efficacy and knowledge for the integration of technology in mathematics instruction at urban schools. In K. V. Adolphson \& T. M. Olson (Eds.), Proceedings of the 43rd annual meeting of the Research Council on Mathematics Learning (pp. 101-108). Retrieved March 4, 2018, from https://rusmp.rice.edu/sites/g/files/bxs 1546/f/teachers' self-efficacy.pdf

Drayton, B., Falk, J. K., Stroud, R., Hobbs, K., \& Hammerman, J. (2010). After installation: Ubiquitous computing and high school science in three experienced high-technology schools. Journal of Technology, Learning, and Assessment, 9(3), $1-57$.

Dunleavy, M., Dexter, S., \& Heinecke, W. (2007). What added value does a 1:1 student to laptop ratio bring to technology-supported teaching and learning? Journal of Computer Assisted Learning, 440-452. 
Dutton, W., \& Helsper, E. (2007). Oxford internet survey 2007 report: The Internet in Britain. Retrieved March 25, 2018, from http://oxis.oii.ox.ac.uk/wpcontent/uploads/2014/11/OxIS-2013.pdf

Eristi, S., Kurt, A., \& Dindar, M. (2012). Teachers' views about effective use of technology in classrooms. Journal of Qualitative Inquiry, 3(2), 30-41.

Ferguson, T. B. (2012). Technology expenditures: A policy analysis in a selected school and return on investment (Doctoral dissertation, University of Florida). Retrieved from https://search.proquest.com/docview/1369522124

Foulger, T. S., Wetzel, K., Lindsey, L., Buss, R. \& Pasquel, S. (2016). Using TPACK as a professional development framework: Benefits, limitations, and exploration of other possible frames. In G. Chamblee \& L. Langub (Eds.), Proceedings of society for information technology \& teacher education international conference (pp. 2842-2849). Savannah, GA: Association for the Advancement of Computing in Education (AACE).

Fullan, M. (2002). Leadership and sustainability. Principal Leadership, 3(4), 1-9. Retrieved from https://michaelfullan.ca/wpcontent/uploads/2016/06/13396047460.pdf

Fullan, M. (2007). Change the terms for teacher learning. JSD: Thought Leader, 28(3), 35-36. Retrieved January 18, 2018, from http://michaelfullan.ca/wpcontent/uploads/2016/06/13396074650.pdf 
Garet, M., Porter, A., Desimone, L., Birman, B., \& Yoon, K. (2001). What makes professional development effective? Results from a national sample of teachers. American Educational Research Journal, 38(4), 915-945. Retrieved February 23, 2018, from https://www.imoberg.com/files/Unit_D_ch._24_-_Garet_et_al._article.pdf

General Assembly of North Carolina. (2013, March 15). House Bill 23. Retrieved March 5, 2018, from https://www.ncleg.net/Sessions/2013/Bills/House/PDF/H23v5.pdf

Gibbons, S. (2007). Redefining the roles of Information professionals in higher education to engage the net generation. Paper presented at EDUCAUSE, Australasia.

Greaves, T., Hayes, J., Wilson, L., Gielniak, M., \& Peterson, E. (2010). Project RED key findings. Shelton, CT: MDR.

Greaves, T., Hayes, J., Wilson, L., Gialniak, M., \& Peterson, E. (2012). Education through technology: The project red roadmap for transformation. Eugene, OR: International Society for Technology in Education. Retrieved September 26, 2017, from http://one-to-oneinstitute.org/images/books/ISTE_Book.pdf

Gulamhussein, A. (2013a). Teaching the teachers: Effective professional development in an era of high stakes testing. Center for Public School Education, 1-47. Retrieved January 20, 2018, from http://www.centerforpubliceducation.org/MainMenu/Staffingstudents/Teaching-the-Teachers-Effective-ProfessionalDevelopment-in-an-Era-of-High-Stakes-Accountability/Teaching-the-TeachersFull-Report.pdf

Gulamhussein, A. (2013b). The core of professional development. American School Board Journal, 1-37. 
Hanson, B. A. (2014). The impact of professional development on early implementation of a 1:1 laptop initiative. (Doctoral Dissertation, Lindenwood University, Missouri) Retrieved November 5, 2017, from https://pqdtopen.proquest.com/doc/1625678114.html?FMT=AI

Hargreaves, A., \& Fink, D. (2006). Sustainable leadership. San Francisco, CA: Jossey Bass.

Higgins, J., \& Russell, M. (2003). Teachers' beliefs about technology-related professional development. Boston, MA: Technology and Assessment Study Collaborative, Boston College.

Hill, H., Blazar, D., \& Lynch, K. (2015). Resources for teaching: Examining personal and institutional predictors of high quality instruction. Sage and Open Access, 1, 1-23. Retrieved February 8, 2018, from https://journals.sagepub.com/doi/pdf/10.1177/2332858415617703

Hitt, M. (2011). Relevance of strategic management theory and research for supply chain management. Journal of Supply Chain Management, 47(1), 9-13.

Hogue, R. (2013). Considerations for a professional development program to support iPads in higher education teaching. Uniquitous Learning: An International Journal, 5(1), 22-35. Retrieved September 27, 2017, from https://ruor.uottawa.ca/bitstream/10393/24274/1/Hogue_Rebecca_2013_Consider ations_for_a_Professional_Development_Program.pdf

Holcomb, T., Holmes, R., \& Connelly, B. (2009). Making the most of what you have: Managerial ability as a source of resource value creation. Strategic Management Journal, 30(5), 457-485. 
Howe, N., \& Strauss, W. (2000). Millennials rising: The next generation. New York, NY: Vintage Books.

Jones, C., \& Shao, B. (2011). The net generation and digital natives: Implications for higher education. New York: Higher Education Academy.

Kenney, S. (2011). Teaching young children how to sing: one school's experience. National Association for Music Education, 24(2), 52-56.

Knapp, W. M. (2017). The impact of TPACK and teacher technology efficacy on social studies teachers' use of technology in the classroom (Doctoral Thesis, University of Minnesota, USA). Retrieved from https://conservancy.umn.edu/bitstream/handle/11299/193425/Knapp_umn_0130E _18737.pdf? sequence $=1$

Kurt, A., Girgin, U., \& Odabasi, F. (2011). Technology integration issues in a special education school in Turkey. Cypriot Journal of Educational Services, 6(1), 13-21.

Lawless, K., \& Pellegrino, J. (2007). Professional development in integrating technology into teaching and learning: Knowns, unknowns, and ways to pursue better questions and answers. Review of Educational Research, 77(4), 575-614.

Livingstone, S., \& Helsper, E. (2008). Gradations in digital inclusion: Children, young people and the digital divide. London School of Economics Research Online, 671-696. Retrieved May 8, 2018, from http://citeseerx.ist.psu.edu/viewdoc/download?doi=10.1.1.455.5111\&rep=rep1\&t ype $=$ pdf 
Majeski, M. (2013). Middle school teachers and principals perspectives on technology. (Doctoral Dissertation) Retrieved November 5, 2017, from https://digitalcommons.unl.edu/cgi/viewcontent.cgi?article=1155\&context $=$ cehse daddiss

Marzano, R., \& Waters, T. (2009). District leadership that works: Striking the right balance. Bloomington, IN: Solution Tree.

Miranda, H., \& Russell, M. (2011). Predictors of teacher-directed student use of technology in elementary classrooms: A multilevel SEM approach using data from the USEIT study. Journal of Research on Technology in Education, 43(4), 301-323.

Mishra, P., \& Koehler, M. (2006). Technological pedagogical content knowledge: A framework for teacher knowledge. Teachers College Record, 108, 1017-1054. Retrieved April 4, 2018, from http://one2oneheights.pbworks.com/f/MISHRA_PUNYA.pdf

Mizell, H. (2010). Why professional development matters. Retrieved November 26, 2018, from https://learningforward.org/docs/defaultsource/pdf/why_pd_matters_web.pdf

Nadelson, L., Bennett, D., Gwilliam, E., Howlett, C., \& Oswalt, S. (2013). The intersection of preservice teachers' confidence, perceptions, and ideas for using instructional technology for teaching and learning. International Journal of Higher Education, 2(4), 75-90. Retrieved from http://scholarworks.boisestate.edu/cgi/viewcontent.cgi?article=1118\&context=cifs facpubs

No Child Left Behind Act of 2001, Pub. L. No. 107-110, § 115, Stat. 1425 (2002). 
North Carolina Department of Public Instruction. (2016, June). NC digital learning competencies for educators. Retrieved May 4, 2018, from http://www.dpi.state.nc.us/dtl/digitallearningnc/competencies/

North Carolina State Board of Education. (2017). Duty to propose a state school technology plan. Retrieved February 12, 2018, from https://www.ncleg.net/enactedlegislation/statutes/html/bysection/chapter_115c/gs _115c-102.6.html

Oblinger, D., \& Oblinger, J. (2005). Educating the net generation. Educause. Retrieved from https://www.educause.edu/ir/library/PDF/pub7101.PDF

Palfrey, J., \& Gasser, U. (2008). Born digital: Understanding the first generation of digital natives. New York, NY: Basic Book.

PBS. (2013, February 4). PBS survey finds teachers are embracing digital resources to propel student learning. Retrieved May 16, 2018, from http://www.pbs.org/about/blogs/news/pbs-survey-finds-teachers-are-embracingdigital-resources-to-propel-student-learning/

Penuel, W. (2006). Implementation and effects of one-to-one computing initiatives: A research synthesis. International Society for Technology in Education, 38(3), 329-348. Retrieved August 20, 2017, from http://citeseerx.ist.psu.edu/viewdoc/download?doi=10.1.1.461.7049\&rep=rep1\&t ype $=$ pdf

Pope, C., \& Mays, N. (1995). Qualitative research: Reaching the parts other methods cannot reach: An introduction to qualitative methods in health and health services research. The BMJ, 311-342. doi:https://doi.org/10.1136/bmj.311.6996.42 
Prensky, M. (2011). A huge leap for the classroom. Retrieved February 4, 2018, from http://marcprensky.com/writing/Prensky-EDTECH-LearningCatalytics-Nov-Dec2011-FINAL.pdf

Raulston, C., \& Wright, V. (2010). Teachers' perceptions and attitudes of one teacher laptop initiative: Connections toward 21st century learning. Meridian: A Kindergarten Through High School Information and Communication Technologies Journal, 13(1), 1-7.

Schreier, M. (2012). Qualitative content analysis in practice. Thousand Oaks, CA: Sage.

Sell, R. G., Cornelius-White, J., Chang, C. W., McLean, A., \& Roworth, W. R. (2012). A Meta-synthesis of research on one-to-one initiatives in K-12 education. Unpublished manuscript, Institute for School Improvement, Missouri State University, Springfield, Missouri.

Shapely, K., Sheehan, D., Maloney, C., \& Caranikas-Walker, F. (2009). Effects of technology immersion on middle school students' learning opportunities and achievement. Texas Center for Educational Research, 1-168. Retrieved March 5, 2018, from https://files.eric.ed.gov/fulltext/ED536296.pdf

Shin, W. S., Han, I., \& Kim, I. (2014). Teachers' technology use and the change of their pedagogical beliefs in Korean educational context. International Education Studies, 7(8), 1-12. Retrieved January 20, 2018, from https://files.eric.ed.gov/fulltext/EJ1070399.pdf

Shulman, L. S. (1987). Knowledge and teaching: Foundations of the new reform. Harvard Educational Review, 57, 1-22. 
Storz, M., \& Hoffman, A. (2013). Examining response to a one-to-one computer initiative: student and teacher voices. Research in Middle Level Education, 36(6), 1-18. Retrieved January 20, 2018, from https://files.eric.ed.gov/fulltext/EJ995733.pdf

Suhr, K., Hernandez, D., Grimes, D., \& Warschauer, M., (2010). Laptops and fourthgrade literacy: Assisting the jump over the fourth-grade slump. The Journal of Technology, Learning, and Assessment, 9(7), 1-46.

Sutherland, C. (2016). Digital natives: 4 ways technology has changes 'the' student. Explorance. Retrieved November 26, 2017, from https://explorance.com/2016/03/digital-natives-4-ways-technology-changedstudent/

Tapscott, D. (2009). Grown up digital: How the net generation is changing your world. New York, NY: McGraw Hill.

TPack Online (2012, September 24). What is TPACK. Retrieved May 5, 2018, from http://www.tpack.org/

Trilling, B., \& Fadel, C. (2009). 21st century skills: Learning for life in our times. San Francisco, CA: John Wiley and Sons, Inc.

Tucker, P. D., \& Stronge, J. H. (2018). Linking teacher evaluation and student learning. Retrieved November 01, 2018, from http://www.ascd.org/publications/books/104136/chapters/The-Power-of-anEffective-Teacher-and-Why-We-Should-Assess-It.aspx

Tweed, S. R. (2013). Technology implementations: Teacher age, experience, selfefficacy, and professional development as related to classroom technology integration (Doctoral Dissertation). Retrieved from https://dc.etsu.edu/etd/1109/ 
United States Department of Education. (2010). Transforming American education:

Learning powered by technology. Retrieved from

https://www.ed.gov/sites/default/files/netp2010.pdf

United States Department of Education. (2013a). Expanding evidence approaches for learning in a digital world. Retrieved from https://tech.ed.gov/wpcontent/uploads/2014/11/Expanding-Evidence.pdf

United States Department of Education. (2013b). Every student succeeds act. Retrieved May 5, 2018, from https://www.ed.gov/essa

Weber, R. (2012). Evaluating and developing theories in the information systems discipline. Journal of the Association for Information Systems, 13(1), 1-31.

Yoon, K., Duncan, T., Lee, S., Scarloss, B., \& Shapely, K. (2007). Reviewing the evidence on how teacher professional development affects student achievement. Retrieved January 20, 2018, from https://ies.ed.gov/ncee/edlabs/regions/southwest/pdf/REL_2007033.pdf

Zucker, A., \& Light, D. (2005). Laptop Programs for students. Science, 323(5910), 8285. 
Appendix A

Survey Questions 
Please answer the following demographic questions that relate to you as an educator.

1. In what district are you employed?

2. How many years have you taught in your career as a certified teacher?
A. Less than 1 year
B. 1-2 years
C. 3-5 years
D. 6-10 years
E. 11-15 years
F. More than 15 years

3. Identify your competency level with technology.
A. Novice
B. Intermediate
C. Advance
D. Expert

Please answer the following questions related to the length of professional development training that you have experienced in preparation for the 1:1 Computer Initiative. The following terms have been defined for the purpose of this study to assist your thought process in answering the survey questions:

1 to 1 Computing Initiative. A learning initiative, by which students are given a computing device for use during learning, be it at school or outside of regular school hours. (Bebell \& O’Dwyer, 2010; Castle, 2012)

Professional Development. Professional development involves workshops, courses, programs, and related activities that are designed presumably to provide teachers with new ideas, skills, and competencies necessary for improvement in the classroom. (Fullan, 2007, p. 35)

4. How long have you had access to a computing device that is similar to the one that your students are using in the one-to-one initiative?
A. Less than One Semester
B. One Semester 

C. One Year
D. More than One Year

5. How long has your school undergone professional development specifically designed to prepare you for the implementation of the 1:1 Computing Initiative?
A. No formal preparation
B. One (1) Semester
C. Two (2) Semesters
D. Three (3) Semesters
E. Four (4) Semesters
F. Five (5) Semesters
G. Six (6) Semesters
H. More than Six (6) Semesters

Please answer the following questions by rating the value of each specific type of professional development to its value in your own individual preparation for the 1:1 a computing initiative. You may elect N/A if you did not participate in any of these types of professional development.

6. Rate the following types of professional development as to its respective value in your individual preparation for the 1:1 Computing Initiative:

\begin{tabular}{|l|l|l|l|l|l|l|}
\hline & $\begin{array}{l}\text { No Value } \\
\text { to My } \\
\text { Preparation }\end{array}$ & $\begin{array}{l}\text { Little Value } \\
\text { to My } \\
\text { Preparation }\end{array}$ & $\begin{array}{l}\text { Marginal } \\
\text { Value to } \\
\text { My } \\
\text { Preparation }\end{array}$ & $\begin{array}{l}\text { Good } \\
\text { Value to } \\
\text { My } \\
\text { Preparation }\end{array}$ & $\begin{array}{l}\text { Significant } \\
\text { Value to } \\
\text { My } \\
\text { Preparation }\end{array}$ & N/A \\
\hline $\begin{array}{l}\text { Learning to use } \\
\text { Hardware (Ex: } \\
\text { Laptops, } \\
\text { Projectors, } \\
\text { Smart Boards, } \\
\text { etc.) }\end{array}$ & & & & & \\
\hline $\begin{array}{l}\text { Learning to use } \\
\text { Software } \\
\text { Applications } \\
\text { and Programs } \\
\text { (Ex: Microsoft }\end{array}$ & & & & & & \\
\hline
\end{tabular}




\begin{tabular}{|l|l|l|l|l|l|}
\hline Office, Prezi, & & & & & \\
Edmondo, & & & & \\
Geogebra, etc.) & & & & & \\
\hline Learning to use & & & & & \\
Content & & & & \\
Management & & & & & \\
Ind & & & & \\
Delivery & & & & \\
Platforms (Ex. & & & & & \\
Blackboard, & & & & & \\
Angel, Moodle, & & & & & \\
etc.) & & & & & \\
\hline Learning to & & & & & \\
implement the & technology & & & & \\
within & & & & & \\
instruction & & & & & \\
\hline
\end{tabular}

Please answer the following questions by indicating the frequency of your use of the specific instructional technology practice both prior to $1: 1$ computing implementation and the initial implementation of the computing initiative.

7. Based on the time spent on professional development, how often did you use technology in your plan for instruction?

\begin{tabular}{|l|l|l|l|l|l|l|}
\hline & Never & $\begin{array}{l}\text { Once or } \\
\text { Twice a } \\
\text { Year }\end{array}$ & $\begin{array}{l}\text { Once or } \\
\text { Twice a } \\
\text { Semester }\end{array}$ & $\begin{array}{l}\text { Once or } \\
\text { Twice a } \\
\text { Month }\end{array}$ & $\begin{array}{l}\text { Once or } \\
\text { Twice a } \\
\text { Week }\end{array}$ & Daily \\
\hline $\begin{array}{l}\text { Prior to 1:1 } \\
\text { Computing } \\
\text { Initiative } \\
\text { Implementation }\end{array}$ & & & & & & \\
\hline $\begin{array}{l}\text { During 1:1 } \\
\text { Computing } \\
\text { Initiative } \\
\text { Implementation }\end{array}$ & & & & & & \\
\hline
\end{tabular}

8. Based on the time spent on professional development, how often did you use technology to deliver instruction to your class?

\begin{tabular}{|l|l|l|l|l|l|l|}
\hline & \multirow{2}{*}{ Never } & $\begin{array}{l}\text { Once or } \\
\text { Twice a } \\
\text { Year }\end{array}$ & $\begin{array}{l}\text { Once or } \\
\text { Twice a } \\
\text { Semester }\end{array}$ & $\begin{array}{l}\text { Once or } \\
\text { Twice a } \\
\text { Month }\end{array}$ & $\begin{array}{l}\text { Once or } \\
\text { Twice a } \\
\text { Week }\end{array}$ & \multirow{2}{*}{ Daily } \\
\hline
\end{tabular}




\begin{tabular}{|l|l|l|l|l|l|l|}
\hline Prior to $1: 1$ & & & & & & \\
Computing & & & & & & \\
Initiative & & & & & \\
Implementation & & & & & & \\
\hline During $1: 1$ & & & & & \\
Computing & & & & & & \\
Initiative & & & & & & \\
Implementation & & & & & & \\
\hline
\end{tabular}

9. Based on the time spent on professional development, how often did you use technology to assess student learning?

\begin{tabular}{|l|l|l|l|l|l|l|}
\hline & Never & $\begin{array}{l}\text { Once or } \\
\text { Twice a } \\
\text { Year }\end{array}$ & $\begin{array}{l}\text { Once or } \\
\text { Twice a } \\
\text { Semester }\end{array}$ & $\begin{array}{l}\text { Once or } \\
\text { Twice a } \\
\text { Month }\end{array}$ & $\begin{array}{l}\text { Once or } \\
\text { Twice a } \\
\text { Week }\end{array}$ & Daily \\
\hline $\begin{array}{l}\text { Prior to 1:1 } \\
\text { Computing } \\
\text { Initiative } \\
\text { Implementation }\end{array}$ & & & & & & \\
\hline $\begin{array}{l}\text { During 1:1 } \\
\text { Computing } \\
\text { Initiative } \\
\text { Implementation }\end{array}$ & & & & & & \\
\hline
\end{tabular}

10. Based on the time spent on professional development, how often did you use digital resources to supplement your existing textbook and/or curriculum?

\begin{tabular}{|l|l|l|l|l|l|l|}
\hline & Never & $\begin{array}{l}\text { Once or } \\
\text { Twice a } \\
\text { Year }\end{array}$ & $\begin{array}{l}\text { Once or } \\
\text { Twice a } \\
\text { Semester }\end{array}$ & $\begin{array}{l}\text { Once or } \\
\text { Twice a } \\
\text { Month }\end{array}$ & $\begin{array}{l}\text { Once or } \\
\text { Twice a } \\
\text { Week }\end{array}$ & Daily \\
\hline $\begin{array}{l}\text { Prior to 1:1 } \\
\text { Computing } \\
\text { Initiative } \\
\text { Implementation }\end{array}$ & & & & & & \\
\hline $\begin{array}{l}\text { During 1:1 } \\
\text { Computing } \\
\text { Initiative } \\
\text { Implementation }\end{array}$ & & & & & & \\
\hline
\end{tabular}

11. Based on the time spent on professional development, how often did you use technology to create and/or download presentations that can be utilized by students outside of the classroom? 


\begin{tabular}{|l|l|l|l|l|l|l|}
\hline & Never & $\begin{array}{l}\text { Once or } \\
\text { Twice a } \\
\text { Year }\end{array}$ & $\begin{array}{l}\text { Once or } \\
\text { Twice a } \\
\text { Semester }\end{array}$ & $\begin{array}{l}\text { Once or } \\
\text { Twice a } \\
\text { Month }\end{array}$ & $\begin{array}{l}\text { Once or } \\
\text { Twice a } \\
\text { Week }\end{array}$ & Daily \\
\hline $\begin{array}{l}\text { Prior to } 1: 1 \\
\text { Computing } \\
\text { Initiative } \\
\text { Implementation }\end{array}$ & & & & & & \\
\hline $\begin{array}{l}\text { During } 1: 1 \\
\text { Computing } \\
\text { Initiative } \\
\text { Implementation }\end{array}$ & & & & & & \\
\hline
\end{tabular}

12. How often did you use technology to differentiate or personalize instruction to meet the unique needs of individual students in your classroom?

\begin{tabular}{|l|l|l|l|l|l|l|}
\hline & Never & $\begin{array}{l}\text { Once or } \\
\text { Twice a } \\
\text { Year }\end{array}$ & $\begin{array}{l}\text { Once or } \\
\text { Twice a } \\
\text { Semester }\end{array}$ & $\begin{array}{l}\text { Once or } \\
\text { Twice a } \\
\text { Month }\end{array}$ & $\begin{array}{l}\text { Once or } \\
\text { Twice a } \\
\text { Week }\end{array}$ & Daily \\
\hline $\begin{array}{l}\text { Prior to } 1: 1 \\
\text { Computing } \\
\text { Initiative } \\
\text { Implementation }\end{array}$ & & & & & & \\
\hline $\begin{array}{l}\text { During 1:1 } \\
\text { Computing } \\
\text { Initiative } \\
\text { Implementation }\end{array}$ & & & & & & \\
\hline
\end{tabular}

13. How often did you create a learning activity designed to challenge students to think in a critical manner?

\begin{tabular}{|l|l|l|l|l|l|l|}
\hline & Never & $\begin{array}{l}\text { Once or } \\
\text { Twice a } \\
\text { Year }\end{array}$ & $\begin{array}{l}\text { Once or } \\
\text { Twice a } \\
\text { Semester }\end{array}$ & $\begin{array}{l}\text { Once or } \\
\text { Twice a } \\
\text { Month }\end{array}$ & $\begin{array}{l}\text { Once or } \\
\text { Twice a } \\
\text { Week }\end{array}$ & Daily \\
\hline $\begin{array}{l}\text { Prior to 1:1 } \\
\text { Computing } \\
\text { Initiative } \\
\text { Implementation }\end{array}$ & & & & & & \\
\hline $\begin{array}{l}\text { During 1:1 } \\
\text { Computing } \\
\text { Initiative } \\
\text { Implementation }\end{array}$ & & & & & & \\
\hline
\end{tabular}


14. How often did you use technology to create your own web page, or use a content management platform, where students can access learning materials and/or turn in assignments in a digital format?

\begin{tabular}{|l|l|l|l|l|l|l|}
\hline & Never & $\begin{array}{l}\text { Once or } \\
\text { Twice a } \\
\text { Year }\end{array}$ & $\begin{array}{l}\text { Once or } \\
\text { Twice a } \\
\text { Semester }\end{array}$ & $\begin{array}{l}\text { Once or } \\
\text { Twice a } \\
\text { Month }\end{array}$ & $\begin{array}{l}\text { Once or } \\
\text { Twice a } \\
\text { Week }\end{array}$ & Daily \\
\hline $\begin{array}{l}\text { Prior to } 1: 1 \\
\text { Computing } \\
\text { Initiative } \\
\text { Implementation }\end{array}$ & & & & & & \\
\hline $\begin{array}{l}\text { During } 1: 1 \\
\text { Computing } \\
\text { Initiative } \\
\text { Implementation }\end{array}$ & & & & & & \\
\hline
\end{tabular}

15. How often did you ask students to use digital technology to complete classroom learning assignments?

\begin{tabular}{|l|l|l|l|l|l|l|}
\hline & Never & $\begin{array}{l}\text { Once or } \\
\text { Twice a } \\
\text { Year }\end{array}$ & $\begin{array}{l}\text { Once or } \\
\text { Twice a } \\
\text { Semester }\end{array}$ & $\begin{array}{l}\text { Once or } \\
\text { Twice a } \\
\text { Month }\end{array}$ & $\begin{array}{l}\text { Once or } \\
\text { Twice a } \\
\text { Week }\end{array}$ & Daily \\
\hline $\begin{array}{l}\text { Prior to } 1: 1 \\
\text { Computing } \\
\text { Initiative } \\
\text { Implementation }\end{array}$ & & & & & & \\
\hline $\begin{array}{l}\text { During } 1: 1 \\
\text { Computing } \\
\text { Initiative } \\
\text { Implementation }\end{array}$ & & & & & & \\
\hline
\end{tabular}

16. How often did you ask students to collaborate on assignments?

\begin{tabular}{|l|l|l|l|l|l|l|}
\hline & Never & $\begin{array}{l}\text { Once or } \\
\text { Twice a } \\
\text { Year }\end{array}$ & $\begin{array}{l}\text { Once or } \\
\text { Twice a } \\
\text { Semester }\end{array}$ & $\begin{array}{l}\text { Once or } \\
\text { Twice a } \\
\text { Month }\end{array}$ & $\begin{array}{l}\text { Once or } \\
\text { Twice a } \\
\text { Week }\end{array}$ & Daily \\
\hline $\begin{array}{l}\text { Prior to } 1: 1 \\
\text { Computing } \\
\text { Initiative } \\
\text { Implementation }\end{array}$ & & & & & & \\
\hline $\begin{array}{l}\text { During } 1: 1 \\
\text { Computing } \\
\text { Initiative } \\
\text { Implementation }\end{array}$ & & & & & & \\
\hline
\end{tabular}


17. How often did you ask students to post their work to or communicate with a global audience (outside of your school setting)?

\begin{tabular}{|l|l|l|l|l|l|l|}
\hline & Never & $\begin{array}{l}\text { Once or } \\
\text { Twice a } \\
\text { Year }\end{array}$ & $\begin{array}{l}\text { Once or } \\
\text { Twice a } \\
\text { Semester }\end{array}$ & $\begin{array}{l}\text { Once or } \\
\text { Twice a } \\
\text { Month }\end{array}$ & $\begin{array}{l}\text { Once or } \\
\text { Twice a } \\
\text { Week }\end{array}$ & Daily \\
\hline $\begin{array}{l}\text { Prior to } 1: 1 \\
\text { Computing } \\
\text { Initiative } \\
\text { Implementation }\end{array}$ & & & & & & \\
\hline $\begin{array}{l}\text { During } 1: 1 \\
\text { Computing } \\
\text { Initiative } \\
\text { Implementation }\end{array}$ & & & & & & \\
\hline
\end{tabular}

18. Please state if you would like to participate in an interview? If you do not want to participate please state no in the response section. If you would like to participate in the interview process please state yes, and state your planning time and the time that you would prefer to be interviewed. Thanks so much for your time. 
Appendix B

Permission Request 
XXXXXXXX

January 24, 2018

Dr. Damian Bebell

Boston College

Boston Massachusetts

Dear Dr. Bebell,

I am requesting permission to reprint survey questions that includes questions from a teacher survey that was developed for the Berkshire Wireless Learning Initiative (2008) created by the Technology and Assessment Study Collaboration from Boston College which is located in the following work:

Author: Bradley Hanson, Ed.D.

Title of the work: The Impact of Professional Development on Early Implementation of a 1:1 Laptop Initiative

ISBN: 489771-1

Year of publication: 2013

A copy of the material I would like to use is enclosed is attached, and is in Appendix A of the attachment. Please send me a word copy of the survey please.

I would like to include the above material as part of the following book that I am preparing:

Author: Kerry Morrison

Title of work: Thesis

Completion

Publisher: Gardner-Webb University

Publication date: 2018

I request non-exclusive world rights to use this material in my work, in all languages and for all editions and formats, including digital/electronic. These rights will in no way restrict republication of the material in any other form by you or by others authorized by you.

If you agree with the terms as described above, please sign and return the letter to me, specifying any credit line, fees, or other conditions you require. Your signing of this letter confirms that you own the copyright to the above described material. If you do not currently hold the rights, I would appreciate any information that can help me contact the rights holder.

I would be very grateful for your permission. If you require any additional information, do not hesitate to contact me at the address above, email at XXXXXX, and via telephone at XXXXXXX.

Sincerely,

Mrs. Kerry Morrison 
The above request is approved on the understanding that full credit will be given to the source.

Damian Bebell

Name and Title

dongulin

Signature
Boston College

Company Affiliation

January 25, 2018

Date 
Appendix C

Permission Request 
Permission Request

Bradley Hanson. Ed.D

Dear Bradley Hanson, Ed.D,

I am requesting permission to reprint survey questions from the following work:

Author: Bradley Hanson, Ed.D.

Title of the work: The Impact of Professional Development on Early Implementation of a

1:1 Laptop Initiative

ISBN: 489771-1

Year of publication: 2014

A copy of the material I would like to use is enclosed is attached, and is in Appendix A of the attachment. Please send me a word copy of the survey please.

I would like to include the above material as part of the following book that I am preparing: Author: Kerry Morrison

Title of work: Thesis Completion

Publisher: Gardner-Webb University

Publication date: 2018

I request non-exclusive world rights to use this material in my work, in all languages and for all editions and formats, including digital/electronic. These rights will in no way restrict republication of the material in any other form by you or by others authorized by you.

If you agree with the terms as described above, please sign and return the letter to me, specifying any credit line, fees, or other conditions you require. Your signing of this letter confirms that you own the copyright to the above described material. If you do not currently hold the rights, I would appreciate any information that can help me contact the rights holder.

I would be very grateful for your permission. If you require any additional information, do not hesitate to contact me at the address above, email at and via telephone at

Sincerely,

Mrs. Kerry Morrison

The above request is approved on the understanding that full credit will be given to the source. Pras Hanso:

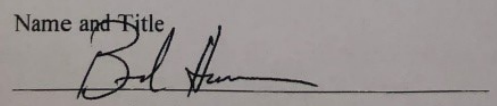

Signature

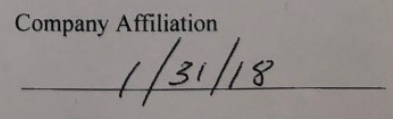

Date 
Appendix D

Survey Participation Informed Consent Form 


\section{Title of Study}

Teacher Perceptions of the Impact of Quality Professional Development on the Sustainability of a One to One Computing Initiative

\section{Researcher}

Kerry Morrison, Graduate student at Gardner-Webb University

\section{Purpose}

The purpose of this research study is see how professional development and exposure of teachers to technology prior to implementation can assist with the sustaining of a one to one computing initiative. Your responses to the survey questions will help the researcher determine how professional development and teacher exposure to technology can assist to sustain a one to one computing initiative.

\section{Procedure}

\section{What you will do in the study:}

If you agree to participate, you will be asked to complete a 16 question survey which asks you to provide your experiences and use of technology in your instruction since your school has started its one to one computing initiative. You can skip any question that causes discomfort and you are able to cease completing the survey at any time. You will also be asked to volunteer for an interview.

\section{Time Required}

It is anticipated that the study will require about 10-15 minutes of your time.

\section{Voluntary Participation}

Participation in this study is voluntary. You have the right to withdraw from the research study at any time without penalty. You also have the right to refuse to answer any question(s) for any reason without penalty. If you choose to withdraw, you may request that any of your data which has been collected be destroyed unless it is in a de-identified state.

\section{Confidentiality}

Data will be collected from you electronically via the SurveyMonkey.com website when you complete the online survey provided to you via the link. Data will be stored electronically on the SurveyMonkey.com website. At the close of the survey, the data will be extracted from the site to code responses. Once responses have been coded and analyzed, they will be deleted. Because of the nature of the data, it may be possible to deduce your identity; however, there will be no attempt to do so, and your data will be reported in a way that will not identify you.

\section{$\underline{\text { Risks }}$}

There are no known risks associated with this research study; however, as with any online related activity the risk of a breach of confidentiality is always possible. To the best of my ability your answers in this study will remain confidential. I will minimize 
any risks by avoiding collecting personal data and coding your responses to avoid any personal identifiers.

\section{Benefits}

There are no direct benefits associated with participation in this study. The study may help us to understand how professional development and teacher exposure to technology may assist in the sustaining of a one to one computing initiative. The Institutional Review Board at Gardner-Webb University has determined that participation in this study poses minimal risk to participants.

\section{Payment}

You will receive no payment for participating in the study.

\section{Right to Withdraw from the Study}

You have the right to withdraw from the study at any time without penalty.

\section{How to Withdraw from the Study}

- If you want to withdraw from the study, close your internet tab and responses will not be submitted. There is no penalty for withdrawing.

- If you already submitted your answers, it may be impossible for the researcher to remove your responses from the answer pool as they are anonymous.

If you have questions about the study, contact the following individuals.

Kerry Morrison

Department of Education

Gardner-Webb University

Boiling Springs, NC 28017

XXXXXXX

Bruce Boyles, EdD

Department of Education

Gardner-Webb University

Boiling Springs, NC 28017

XXXXXXX

If the research design of the study necessitates that its full scope is not explained prior to participation, it will be explained to you after completion of the study. If you have concerns about your rights or how you are being treated, or if you have questions, want more information, or have suggestions, please contact:

Dr. David Granniss

Chair of the IRB

Gardner-Webb University

Boiling Springs, NC 28017

Telephone: XXXXXX 


\section{Voluntary Consent by Participant}

I have read the information in this consent form and fully understand the contents of this document. I have had a chance to ask any questions concerning this study and they have been answered for me.

I agree to participate in the confidential survey.

I do not agree to participate in the confidential survey.

Participant Printed Name

Date:

Participant Signature

Date:

You will receive a copy of this form for your records. 
Appendix E

Teacher Script: Interview 
1. What is your perception of technology in education?

2. What are the benefits of using one to one computing at your school?

3. Does your school have any district or school wide protocols as it comes to the using of technology in your classroom?

4. Do you see any changes in student learning since the implementation of one to one computing initiative in your school?

5. Has there been professional development that assists you with your pedagogy in this one to one environment?

6. What type of professional development would be more beneficial to you as your school sustains the one to one initiative?

7. In what ways has the one to one computing initiative influence how time is spent during professional development days?

8. Is there anything that you want to add that I may not have covered? 
Appendix F

Principal Script: Interview 
1. What is your perception of technology in education?

2. What are the benefits of using one to one computing at your school?

3. How long did teachers undergo professional development to prepare them for the one to one initiative prior to implementation?

4. How do you get faculty members interested in the use of technology in their classrooms?

5. How is professional development used to sustain the one to one computing initiative at your school?

6. What type of professional development would be more beneficial to you as your school sustains the one to one initiative?

7. In what ways has the one to one computing initiative influence how time is spent during professional development days?

8. Is there anything that you want to add that I may not have covered? 
Appendix G

Email for Survey Participation 
My name is Kerry Morrison and I am a student at Gardner-Webb University. I am inviting you to participate in a research study titled "Teachers' Perceptions of the Impact of Quality Professional Development on the Sustainability of a One to One Computing Initiative". You were selected to participate in this study because you work a high school in a district that is participating in this survey.

The purpose of this research study is see how professional development and exposure of teachers to technology prior to implementation can assist with the sustaining of a one to one computing initiative. If you agree to take part in this study, you will be asked to complete an online survey. This survey should take 10 minutes to complete.

You may not directly benefit from this research; however, we hope that your participation in the study may help the district to see how to best sustain its one to one computing initiative.

I believe there are no known risks associated with this research study; however, as with any online related activity the risk of a breach of confidentiality is always possible. To the best of my ability your answers in this study will remain confidential. I will minimize any risks by avoiding collecting personal data and coding your responses to avoid any personal identifiers.

Your participation in this study is completely voluntary and you can withdraw at any time. You are free to skip any question that you choose.

The survey can be accessed by clicking:

If you have questions about this project, or if you have a research-related problem, please contact me at any time.

Thanks in Advance!

Kerry Morrison

XXXXXXX 
Appendix $\mathrm{H}$

Interview Participation 


\section{Informed Consent Form}

\section{Title of Study}

Teachers' Perceptions of the Impact of Quality Professional Development on the Sustainability of a One to One Computing Initiative

\section{Researcher}

Kerry Morrison, Graduate student at Gardner-Webb University

\section{$\underline{\text { Purpose }}$}

The purpose of this research study is see how professional development and exposure of teachers to technology prior to implementation can assist with the sustaining of a one to one computing initiative. Your responses to the survey questions will help the researcher determine how professional development and teacher exposure to technology can assist to sustain a one to one computing initiative.

\section{Procedure}

\section{What you will do in the study:}

If you agree to participate, you will be asked to complete a 16 question survey which asks you to provide your experiences and use of technology in your instruction since your school has started its one to one computing initiative. You can skip any question that causes discomfort and you are able to cease completing the survey at any time. You will also be asked to volunteer for an interview.

\section{Time Required}

It is anticipated that the study will require about 20-25 minutes of your time.

\section{Voluntary Participation}

Participation in this study is voluntary. You have the right to withdraw from the research study at any time without penalty. You also have the right to refuse to answer any question(s) for any reason without penalty. If you choose to withdraw, you may request that any of your data which has been collected be destroyed unless it is in a de-identified state.

\section{Confidentiality}

Data will be collected from you electronically via the SurveyMonkey.com website when you complete the online survey provided to you via the link. Data will be stored electronically on the SurveyMonkey.com website. At the close of the survey, the data will be extracted from the site to code responses. Once responses have been coded and analyzed, they will be deleted. Because of the nature of the data, it may be possible to deduce your identity; however, there will be no attempt to do so, and your data will be reported in a way that will not identify you.

\section{$\underline{\text { Risks }}$}

There are no known risks associated with this research study; however, as with any online related activity the risk of a breach of confidentiality is always possible. To the best of my ability your answers in this study will remain confidential. I will minimize 
any risks by avoiding collecting personal data and coding your responses to avoid any personal identifiers.

\section{Benefits}

There are no direct benefits associated with participation in this study. The study may help us to understand how professional development and teacher exposure to technology may assist in the sustaining of a one to one computing initiative. The Institutional Review Board at Gardner-Webb University has determined that participation in this study poses minimal risk to participants.

\section{Payment}

You will receive no payment for participating in the study.

\section{Right to Withdraw from the Study}

You have the right to withdraw from the study at any time without penalty.

\section{How to Withdraw from the Study}

- If you want to withdraw from the study, close your internet tab and responses will not be submitted. There is no penalty for withdrawing.

- If you already submitted your answers, it may be impossible for the researcher to remove your responses from the answer pool as they are anonymous.

If you have questions about the study, contact the following individuals.

Kerry Morrison

Department of Education

Gardner-Webb University

Boiling Springs, NC 28017

XXXXXXXXX

Bruce Boyles, EdD

Department of Education

Gardner-Webb University

Boiling Springs, NC 28017

XXXXXXXXX

If the research design of the study necessitates that its full scope is not explained prior to participation, it will be explained to you after completion of the study. If you have concerns about your rights or how you are being treated, or if you have questions, want more information, or have suggestions, please contact:

Dr. David Granniss

Chair of the IRB

Gardner-Webb University

Boiling Springs, NC 28017

XXXXXXXX 


\section{Voluntary Consent by Participant}

I have read the information in this consent form and fully understand the contents of this document. I have had a chance to ask any questions concerning this study and they have been answered for me.

I agree to participate in the interview.

I I do not agree to participate in the interview.

Participant Printed Name

Date:

Participant Signature

Date:

You will receive a copy of this form for your records. 